NBER WORKING PAPER SERIES

\title{
RELIGIOUS FESTIVALS AND ECONOMIC DEVELOPMENT: EVIDENCE FROM THE TIMING OF MEXICAN SAINT DAY FESTIVALS
}

\author{
Eduardo Montero \\ Dean Yang \\ Working Paper 28821 \\ http://www.nber.org/papers/w28821 \\ NATIONAL BUREAU OF ECONOMIC RESEARCH \\ 1050 Massachusetts Avenue \\ Cambridge, MA 02138 \\ May 2021, Revised January 2022
}

\begin{abstract}
We thank Hoyt Bleakley, Melissa Dell, Mark Dincecco, Marcel Fafchamps, Edgar Franco, Oded Galor, Etienne LeRossignol, Stelios Michalopoulos, Adan Silverio Murillo, Nathan Nunn, Andrei Shleifer, Yuan Tian, Felipe Valencia Caicedo, Diana Van Patten, Marlous van Waijenburg, and seminar participants at Brown, Cornell, University of Michigan, NBER, ASREC, LACEA, RIDGE, Nottingham University, PUC-Chile, the Vancouver School of Economics, University of Göttingen, University of Washington, and University of Chicago for excellent comments and feedback. We thank Colin Case, Israel Diego, Patricia Freitag, Kyle Murphy, Patricia Padilla, Jared Stolove, Erik Tiersten-Nyman, and Hang Yu for outstanding research assistance. We thank Jennifer Alix-Garcia and Emily Sellers for generously sharing data. We are grateful for financial support from several University of Michigan MITRE Faculty Research Grants. The views expressed herein are those of the authors and do not necessarily reflect the views of the National Bureau of Economic Research.
\end{abstract}

NBER working papers are circulated for discussion and comment purposes. They have not been peer-reviewed or been subject to the review by the NBER Board of Directors that accompanies official NBER publications.

(C) 2021 by Eduardo Montero and Dean Yang. All rights reserved. Short sections of text, not to exceed two paragraphs, may be quoted without explicit permission provided that full credit, including (C) notice, is given to the source. 
Religious Festivals and Economic Development: Evidence from the Timing of Mexican Saint Day Festivals

Eduardo Montero and Dean Yang

NBER Working Paper No. 28821

May 2021, Revised January 2022

JEL No. N36,O1,Z12

\begin{abstract}
$\underline{\text { ABSTRACT }}$
Does variation in how religious festivals are celebrated have economic consequences? We study the economic impacts of the timing of Catholic patron saint day festivals in Mexico. For causal identification, we exploit cross-locality variation in festival dates and in the timing of agricultural seasons. We estimate the impact of "agriculturally-coinciding" festivals (those coinciding with peak planting or harvest months) on long-run economic development of localities. Agriculturallycoinciding festivals lead to lower household income and worse development outcomes overall. These negative effects are likely due to lower agricultural productivity, which inhibits structural transformation out of agriculture. Agriculturally-coinciding festivals may nonetheless persist because they also lead to higher religiosity and social capital.
\end{abstract}

\author{
Eduardo Montero \\ Harris School of Public Policy \\ University of Chicago \\ 1307 E 60th St \\ Chicago, IL 60637 \\ and NBER \\ emontero@uchicago.edu \\ Dean Yang \\ University of Michigan \\ Department of Economics and \\ Gerald R. Ford School of Public Policy \\ 735 S. State Street, Room 3316 \\ Ann Arbor, MI 48109 \\ and NBER \\ deanyang@umich.edu
}

An appendix is available at http://www.nber.org/data-appendix/w28821 


\section{Introduction}

Religious festivals are prominent features of social life worldwide, and often account for substantial expenditures in even the poorest societies (Banerjee and Duflo, 2011). How do religious festivals - and differences in their features and timing - affect long-run economic development? Religious festivals in general may promote economic development, for example if they foster the development of social capital, enhance voluntary public good provision, or raise levels of trust in society (Putnam, 2000, Rao, 2001, McCleary and Barro, 2006). On the other hand, devoting substantial resources and time to religious festivals may be detrimental to long-run economic growth, particularly for festivals whose timing coincides with (and crowds out) other growth-stimulating investments (McCleary and Barro, 2019).

It is difficult to credibly estimate the causal impacts of religious practices, such as religious festivals. The features of religious festivals (e.g., their timing on the calendar) are not generally assigned exogenously. The features of festivals could be directly affected by economic development itself, or by other omitted variables that also affect development. Festival characteristics could be chosen (or could evolve endogenously) to enhance positive effects or reduce negative effects on economic development. Additionally, religious festivals are often common to entire societies; opportunities to utilize within-society variation in festivals are rare. Due to these challenges, there is little evidence on the causal impact of variation in religious festival celebrations on economic development.

In this paper, we study how variation in religious festivals that were introduced by European conquerors affects long-run economic development. European colonization went hand in hand with conversion of conquered peoples to Christianity across the globe (Stanley, 1990, MacCulloch, 2009). In the Americas, conversion of the native population to Catholicism facilitated Spanish colonial expansion (McAlister, 1984). European conquerors introduced Christian traditions, replacing endogenously-developed local religious practices, and the new traditions have been highly persistent to the present day (Nunn, 2010). The replacement of indigenous with Christian traditions in the course of colonization is one of history's most widespread - and potentially consequential - natural experiments in culture and economics.

We investigate the impacts of a particular religious practice introduced in 
the Spanish colonization of Mexico: patron saint day festivals. In Mexico and many other Roman Catholic countries, towns and cities celebrate the "patron saint day" of a particular saint or other holy figure that has been historically associated with the town. Hundreds of such celebrated figures have their saint day festivals that are spread throughout the calendar year, on dates set by the Catholic hierarchy in the Vatican. ${ }^{1}$ These saint day festivals are usually local public holidays, and involve substantial time and financial expenditures by local households and governments. Patron saints were typically established by Spanish colonizers, centuries ago, and remained set thereafter.

In recent decades, anthropologists have highlighted potential negative impacts of Catholic saint day festivals on development. Harris (1964) argued that these festivals involved "enormous economic burdens" and "irrational uneconomic" behaviors that impeded development in Latin America. Greenberg (1981, pg. 153-158) notes that the consequences of festivals for development depended on the exact timing of festival expenditures vis-a-vis the agricultural calendar.

To examine how variation in religious festivals may have economic development consequences, we take advantage of two features of the setting. First, festival dates vary greatly across localities. Second, the calendar timing of the main agricultural planting and harvest times also varies tremendously across localities. This means that, for some municipalities, the saint day festival coincides with the planting or harvest season, while in other municipalities it does not.

We exploit this variation in festival timing. We compare municipalities where the festival coincides with the planting or harvest season to municipalities where they do not coincide, measuring differences in household income and other dimensions of economic development. We hypothesize that festivals that coincide with the planting or harvest seasons ("agriculturally-coinciding", or just "coinciding" festivals) negatively affect long-run economic development. During the planting and harvest seasons, households need to devote labor to and make investments in agriculture. If households are time- and liquidity-constrained, festivals occurring in these key time periods may crowd out time and financial investments in agriculture. In the planting season, festivals may crowd out financial investments (e.g., in fertilizer and seeds), reduce time spent in agrigultural labor (e.g., in land preparation), and cause communities to plant at times away

\footnotetext{
${ }^{1}$ For example, towns whose patron saint is St. Arcadius (in Spanish, Arcadio) have their festival on January 12, while for St. Fructus (Fructuoso) the date is October 25.
} 
from the optimal planting date. Harvest festivals may also crowd out harvest labor time or lead to harvesting too early or too late. In addition, harvest festivals occur when communities are flush with agricultural income, and may lead to more temptation consumption than festivals in other seasons. Harvest festivals may thus reduce savings for investment in the next planting season. Agriculturally-coinciding festivals thereby lead to lower agricultural productivity. Persistently lower agricultural productivity impedes the structural transformation of the economy from agriculture to modern sectors.

To conduct our analysis, we assembled a new dataset of patron saint day festival dates for Mexican municipalities. We combine these data with data on locally-specific optimal planting and harvest dates to determine whether festivals occur during planting or harvest periods. We then use numerous data sources from the Mexican government to explore municipality-level development outcomes in the present day.

The main identification assumption of our cross-sectional analysis is that the coincidence of a locality's festival date and the timing of its agricultural seasons is uncorrelated with omitted variables that may also affect long-run economic development. We take three approaches to bolstering the credibility of the identifying assumption. First, we review historical sources on the determination of saints by Mexican municipalities, and find no evidence contradicting our identification assumption. Second, in determining whether a municipality has a coinciding festival, we make two key analytical choices: 1) we use only "official" saint celebration dates set by the Catholic Church in the Vatican, rather than potentially-endogenous actual celebration dates chosen by municipalities, and 2) we determine optimal planting and harvest periods using a global database of agricultural conditions, rather than a municipality's actual planting and harvest dates (which may also be endogenous).

Third, we present a number of empirical tests to confirm the plausibility of the identification assumption, particularly after controlling for key fixed effects and exploiting only cross-town variation within Mexican states. We show that municipalities show no tendency to have festivals occur away from planting or harvest periods. This helps rule out an important endogeneity concern, that communities intentionally choose the timing of festivals to avoid planting or harvest times. If this were occurring differentially for municipalities with certain characteristics, it would raise concerns about selection bias. In addition, we show 
that the propensity to have a festival coincide with planting or harvest is not associated with geographic and historical characteristics that may affect development. These tests support the assumption that the coincidence between a town's festival date and the timing of its agricultural season is plausibly exogenous, and can be used to examine the impacts of agriculturally-coinciding festivals on economic development.

We first investigate the impact of agriculturally-coinciding festivals on development outcomes in the long run. We find that municipalities with agriculturallycoinciding festivals have lower household income, and also score worse on an index of economic development constructed from Mexican Census outcomes. The impacts are large in magnitude: in the long run, coinciding festivals lead to roughly $20 \%$ lower household income, and lower the economic development index by 0.13 standard deviations. Our estimates imply that aggregate GDP in the former New Spain region of Mexico is $4.2 \%$ lower today due to coinciding festivals.

In additional analyses, we explore mechanisms behind our results. Consistent with our conceptual framework, we find that the long-run negative impacts of coinciding festivals across Mexican municipalities occur due to negative impacts in agriculture. Locations with coinciding festivals are less productive in agriculture. They have also experienced less structural transformation: they have higher shares of the labor force in agriculture, and lower shares in modern sectors. These findings are consistent with the economic growth literature, which has highlighted improvements in agricultural productivity and the subsequent transition from agriculture towards the modern sectors as central aspects of the economic development process (Caselli, 2005, Herrendorf et al., 2014).

How could religious practices with such negative economic effects persist? First, it is possible that communities would not notice the year-to-year negative economic effects of coinciding festivals. The long-run negative effect on mean income - roughly $20 \%$ - has emerged over the course of centuries since Spanish conquest. Such a long-run effect on income can accumulate over time from small differences in annual growth rates. For example, if the annual economic growth rate in communities with coinciding festivals is just $0.1 \%$ lower, compounded over 200 years, this would lead to roughly $20 \%$ lower mean income in localities with 
coinciding festivals. ${ }^{2}$

Furthermore, even if communities come to realize that coinciding festivals have negative economic effects, they may continue to persist for another reason: they lead to higher religiosity and social capital. We use detailed survey data from the Americasbarometer from 2008 to 2018 and examine a variety of measures of religiosity and social capital. We find that municipalities with coinciding festivals have higher religious group participation and a higher propensity to say that religion is important in one's life. Higher religiosity may lead to greater adherence to religious customs and traditions, including the celebration and timing of festivals, explaining why coinciding festivals are not changed even if they have negative development consequences. There may thus exist a self-reinforcing cycle in which coinciding festivals reduce development, but raise religiosity, and the increased religiosity helps coinciding festivals persist.

We also find that areas with coinciding festivals have lower income inequality and higher international migration. Both of these additional findings may be consequences of the negative development impact of coinciding festivals.

This paper contributes to the literature on religion and economic development (see Iyer, 2016 and McCleary and Barro, 2006, 2019 for reviews), which is part of a broader literature on culture and development (see reviews by Guiso et al., 2006 and Nunn, 2012). Prior work has found a negative correlation between religious behavior and economic growth in cross-country comparisons (McCleary and Barro, 2006), and that individuals' religious beliefs are associated with attitudes conducive to economic growth (Guiso et al., 2003). ${ }^{3}$ Our work is part of a more recent literature studying the impact of specific religious practices, with a strong focus on identifying causal effects. Bryan et al. (2021) study the impacts of randomly-assigned Christian values education in the Philippines. Stifel et al. (2011) study impacts of work-day taboos on Malagasy agriculture. Beam and Shrestha (2020) examine how perceived fortuitousness of Zodiac years affects Malaysian fertility. Suzuki (2021) studies how (non-religious) quinceañera coming-of-age ceremonies affect household finances in Mexico. Perhaps closest to

\footnotetext{
${ }^{2}$ Related research has found that religious and other holidays persist in spite of negative shortrun reductions in economic growth of $0.1 \%$ or more per year (e.g. Campante and Yanagizawa-Drott, 2015, Schofield, 2020, Wagner, 2021).

3 Alesina et al. (2020) study differences in inter-generational mobility within geographic regions across religious groups in Africa. Waldinger (2017) and Valencia Caicedo (2019) link present-day outcomes in Latin America to prior Catholic missionary activity.
} 
our work, Schofield (2020) examines the short-run impact of variation in the Muslim holiday Ramadan on agricultural output in India, exploiting annual changes in Ramadan's occurrence in the calendar year, as well as spatial heterogeneity in crop choice and crop calendars. Similarly, Campante and Yanagizawa-Drott (2015) exploit differences in the length of Ramadan fasting across countries and years, finding that longer Ramadan fasting has negative short-run impacts on economic growth in Muslim countries. Relative to this more recent body of work, our paper is distinct in that we examine: 1) impacts of religious festival timing using plausibly exogenous historical and geographic variation, and 2) long-run equilibrium differences in development resulting from persistent differences in the costliness of a religious practice, rather than short-run consequences of temporary changes in the costliness of a religious practice.

Second, we contribute to the social science literature on the impacts of religious practices on religiosity and social capital. Prior research has argued that religious practices have social capital benefits (e.g. Putnam, 2000, Deaton and Stone, 2003, Lim and Putnam, 2010). Clingingsmith et al. (2009) estimate the impact of the Muslim Hajj pilgrimage by examining visa lottery applicants in Pakistan, and find that pilgrimage increases religiosity. These social capital benefits of religion are often cited as a potential reason for their persistence despite their effects on economic growth (Bentzen, 2019). Campante and Yanagizawa-Drott (2015) find that longer Ramadan fasting has positive impacts on subjective well-being despite negative effects on economic growth. We contribute to this literature with evidence that a religious practice with negative economic effects, agriculturallycoinciding festivals, may nonetheless persist because of its positive impacts on religiosity.

\section{Conceptual Framework}

We first consider conceptually how festival timing might affect long-run development. The overall argument is as follows. Some festivals occur in periods when there may be time-sensitive investment opportunities or the economic return to labor inputs may be particularly high: agricultural planting and harvest periods. Festivals require devotion of time and financial expenditures. Because of time and liquidity constraints, an "agriculturally-coinciding" (or simply "coinciding") festival crowds out time and financial investments in agriculture. Because festival 
timing on the calendar is persistent, coinciding festivals lead to long-run reductions in agricultural productivity. Persistently lower agricultural productivity hinders the structural transformation out of agriculture.

Despite their negative economic consequences, coinciding festivals could persist if they also lead to higher religiosity. This could occur via two mechanisms. First, coinciding festivals may be a costlier signal of religious devotion, so areas with coinciding festivals could develop higher religiosity. Second, lower development also slows the secularization process, leading to higher religiosity. Increased religiosity can lead to resistance to changing religious traditions, including the celebration and timing of religious festivals. There can thus be a self-reinforcing cycle in which coinciding festivals persist due to higher religiosity, in spite of their negative economic consequences. Areas with coinciding festivals end up with lower levels of economic development in the long run.

\subsection{Agriculturally-Coinciding Festivals}

Agricultural production has distinct planting and harvest seasons, which are locally-specific: they vary across localities due to climatic and geographic variation. During planting and harvest seasons, there are unusually high - but timesensitive - economic returns to labor and financial investments. Festivals' timing on the calendar also varies across localities. Festivals also require devotion of time and financial expenditures. Households are time- and liquidity-constrained (Karlan and Morduch, 2010), so festivals that coincide with planting or harvest seasons may limit their ability to take advantage of time-sensitive economic opportunities.

In the planting season, there are high economic returns to devoting labor to planting activities. When festivals coincide with the planting season, households face competing demands for their labor. They have limited ability to hire outside labor, partly due to standard principal-agent problems, but also because the planting season is a peak time for local labor demand. Agricultural seasons are spatially correlated, and incomplete spatial integration of labor markets makes it difficult to hire agricultural labor from more distant areas not experiencing their own planting season. Relatedly, they may shift their planting labor to suboptimal times before or after the festival, when returns are lower. Planting-coinciding festivals therefore impede households' ability to take full advantage of time-sensitive economic returns to planting season labor. 
Planting-coinciding festivals may also crowd out investments in agricultural inputs (such as fertilizer and seeds). While fully rational farmers could in principle purchase agricultural inputs in prior months (say, just after the prior harvest), in practice farmers may have behavioral biases that lead them to defer input purchases until they are absolutely needed for planting season. Duflo et al. (2011) present a model of present biased and partially-naïve farmers who, due to nonzero utility costs of agricultural input purchases, defer purchases until the last moment before planting. Some farmers who have deferred such purchases end up using their savings on temptation goods instead of agricultural inputs. Consistent with their model, they show that a well-timed nudge to purchase fertilizer some months earlier has positive impacts on fertilizer use in Kenya. This model implies, in our setting, that many farmers may defer input purchases until the last minute before planting. Then, the financial expenditures called for by planting-coinciding festivals may crowd out agricultural investments. Farmers would have to be at least partially naïve about this crowding-out occurring.

The economic returns from planting season labor and financial investments are realized later, in the harvest season. As in the planting season, there are high returns to devoting labor time to harvesting crops. Competing demands for harvest-labor time due to a harvest-coinciding festival could lead to less labor devoted to harvesting, or to harvesting being shifted to a less-optimal period.

Coinciding festivals may have another effect unique to the harvest season. Households should optimally save some portion of their harvest output for investment in the next planting season. Festivals at any time of year may cause temptation spending, but because harvest is a time when localities are particularly flush with income, harvest-coinciding festivals may lead to higher temptation consumption - and depletion of savings - than festivals at other times of the year. As a result, localities with harvest-coinciding festivals may systematically save less of their harvest output for investment in the next planting season. ${ }^{4}$

Lower tourism revenue could be another factor behind negative effects of coinciding festivals. Agricultural seasons are spatially correlated, and tourists

\footnotetext{
4Festivals occurring during harvest times may also reduce farm households' total harvest income by requiring them to sell crops during peak harvest times, when crop prices are low (Burke et al., 2019, Augenblick et al., 2021), to gain liquidity for festival expenditures. While in general equilibrium the community-wide impact of higher harvest-time crop sales is unclear (since this advantages net crop buyers), lower realized incomes for net sellers of crops (farmers) may also have negative impacts on the locality's overall agricultural productivity.
} 
are likely to differentially come from neighboring towns. Because people in neighboring towns would be more time-constrained, tourism to visit coinciding festivals may therefore be lower than to non-coinciding festivals. In addition, in the planting season, the need to spend on one's own planting investments should further depress tourism (and tourist spending) in other towns' coinciding festivals. Coinciding festivals may therefore yield less tourist revenue. This could be an additional channel through which long-run negative impacts of coinciding festivals operate. ${ }^{5}$

In sum, agriculturally-coinciding festivals may reduce the extent to which households take advantage of high-return but time-sensitive economic opportunities in agriculture. Localities with agriculturally-coinciding festivals may then have persistently lower agricultural productivity.

\subsection{Impact on Structural Transformation and Long-Run Economic Growth}

Persistently lower agricultural productivity in places with coinciding festivals could reduce long-run economic growth. In a Malthusian environment (which likely characterizes Mexico before the 2oth century), lower agricultural productivity would lead to reduced fertility and lower population growth (Malthus, 1798, Ashraf and Galor, 2011). Localities with lower populations may then see less endogenous technological progress, and lower economic growth (Kremer, 1993, Galor and Weil, 2000, Aiyar et al., 2008).

Lower growth in the agricultural sector could also dampen overall economic growth by forestalling the structural transformation of the economy towards modern (manufacturing and services) sectors, as has been emphasized in a longrunning literature in development economics (Schultz, 1953, Johnston and Mellor, 1961, Timmer, 1998, Johnson, 2000). Recent theoretical work has formalized this point in two-sector growth models with an agricultural and a modern or nonagricultural sector (Caselli and Coleman, 2001, Caselli, 2005, Gollin et al., 2002, 2007, Restuccia et al., 2008). When there are subsistence constraints (a minimum

${ }^{5} \mathrm{~A}$ tourism-related force pushing in the opposite direction would operate only in the harvest season. Harvest leads to a spike in income, possibly leading to higher temptation to spend on nearby festival tourism. Higher tourist spending could promote long-run development of municipalities with harvest-coinciding festivals. Overall, we do find that harvest-coinciding festivals have negative effects on long-run development (Appendix Table D4), so if this force does operate, our estimate of the negative impact of harvest-coinciding festivals would be a lower bound of the true negative effect. 
agricultural or food consumption requirement), demand for agricultural goods is income-inelastic, and the economy is closed to trade (so that domestic agricultural production is necessary), agricultural productivity needs to rise before labor moves from agriculture to the modern sectors. Agricultural productivity growth leads to overall economic growth and a structural transformation out of agriculture. Recent empirical studies have examined this question, with some finding causal evidence that increases in agricultural productivity lead to structural transformation and economic growth. ${ }^{6}$

\subsection{Religiosity and the Persistence of Coinciding Festivals}

Our empirical analyses will show that communities do not appear to avoid festival celebration dates that coincide with planting and harvest seasons. Why don't communities simply celebrate their saints on different dates, or switch to saints whose festival dates are not agriculturally-coinciding?

Coinciding festivals may raise religiosity, and the increased religiosity may lead to persistence of coinciding festivals. Prior research suggests two channels through which coinciding festivals may raise religiosity. First, agriculturallycoinciding festivals have particularly high economic costs, making them particularly effective signals of religious commitment, leading localities with coinciding festivals to have higher religiosity. In club goods models of religion, costly signals of religious devotion can raise religious participation rates by inducing substitution towards religious from non-religious activities, as well as screening out less-devoted community members (Iannaccone, 1992, Levy and Razin, 2014). Contributing time and resources to religious festivals during the planting and harvest periods can be seen as just such a costly signal of religiosity, since such contributions may come with particularly high costs in terms of foregone economic opportunities.

Second, lower economic development may itself increase religiosity (Durkheim, 1912). Empirical studies have found that higher income levels across societies are associated with lower religiosity (Lipford and Tollison, 2003, Paldam and Gundlach, 2013), and that higher education contributes to secularization (Hungerman, 2014, Becker et al., 2017).

\footnotetext{
${ }^{6}$ See, among others, Foster and Rosenzweig (2004), Nunn and Qian (2011), Bustos et al. (2020), Gollin et al. (2021).
} 
Whatever the mechanism through which coinciding festivals lead to higher religiosity, the increased religiosity may increase adherence to religious traditions such as saint day festivals. There may then be a self-reinforcing cycle: coinciding festivals reduce development and raise religiosity, and the increased religiosity promotes their persistence.

It is important to note that even if localities with coinciding festivals become less developed economically, it is unclear whether households in these localities would have lower utility overall. Higher utility resulting from greater religiosity and lower inequality may offset declines in utility due to lower economic development, making the net effect of coinciding festivals on utility ambiguous.

\section{Saint Day Festivals in Mexico}

\subsection{Cultural and Economic Significance of Saint Day Festivals}

Patron saint day festivals are yearly celebrations that occur in Catholic countries, especially those influenced by Spanish culture. ${ }^{7}$ Such festivals are dedicated to a holy figure considered the protector of a given locality. Hundreds of such holy figures have their festivals throughout the year, on dates set by Catholic leadership in the Vatican. Saint day festivals are typically local public holidays, and involve substantial financial expenditures by local governments as well as households (Lastra et al., 2009).

In Mexico, saint day festivals acquired major economic and cultural significance following Spanish conquest. As part of efforts to convert local populations to Catholicism, saint day festivals became "one of the most important activities of the municipal governments" (Tanck de Estrada, 2005, pg. 31). Gibson (1964) calculated that local governments in the Valley of Mexico in the 17th and 18th centuries spent three-fourths of their annual public sector revenue on festivals. ${ }^{8}$ Historically, festivals typically lasted at least three days, involving processions, masses, sermons, music, dancing, markets, fireworks, bull runs, and feasting (Tanck de Estrada, 2005).

7We use the terms "patron saint day festival" or "saint day festival" in this paper. This is synonymous with "patron saint day fiesta" and "patron saint fiesta".

${ }^{8}$ The festivals became particularly popular because they naturally commingled indigenous and Spanish religious elements (Lastra et al., 2009). 
By the 1790s, patron saint day festivals had become so large that the colonial government imposed limits on municipal government festival spending, calling the "excesses" of the festivals "superfluous and vicious" (Tanck de Estrada and Marichal, 2010, pg. 352). These laws led to the development of the mayordomia (or cargo) social system, where a rotating set of households assumed responsibility for organizing and financing the saint day festival (Beezley and Meyer, 2010, Lastra et al., 2009, Monaghan, 1990, Dewalt, 1975). Approximately 10-15\% of households in villages served as mayordomos in a given year (Dow, 1974, Greenberg, 1981). ${ }^{9}$

Serving as a mayordomo involved significant expenditures, "in many cases to the mayordomos' own financial detriment" (Beezley and Meyer, 2010, pg. 159). Mayordomos had little flexibility on the required expenditure amounts because festival expenses were "fixed by custom and agreement" and "varied hardly at all from year to year" (Gibson, 1964, pg. 130). The financial strain for mayordomos was particularly high during years with poor harvests, as income "depended on the agricultural year and the market price of the produce" (Gibson, 1964, pg. 130). ${ }^{10}$ Brandes (1981, pg. 212) notes that the "invariably high" financial outlays for mayordomos were often so large "that villagers were forced to sell parcels of land in order to meet ritual responsibilities".

Festival preparations and activities were also burdensome for mayordomos in terms of time and effort. Harris (1964, pg. 26) notes, "The burdensome aspect of the cargos and political offices is that they involve considerable expenditure of time and money." Monaghan (1996) notes that "the amount of time and money contributed may vary with the position, but it is always substantial."

Despite the time and financial burden, many households took on the role for

${ }^{9}$ As a result, Greenberg (1981) notes, households had to take on the mayordomo role about once every 6-8 years.

${ }^{10}$ Greenberg (1981, pg. 149) further says that these cash expenditures "force Indians to sell their agricultural surpluses and labor on the market to gain the wherewithal to meet their ceremonial obligations". He calculates that about 50\% of the costs are direct cash expenditures, with the remainder in kind (including labor time). He provides further detail on the community of Yaitepec: "...if goods are computed at their 1973 local market values, the 28 men who served as mayordomos that year spent a total of 127,872 pesos $(\$ 10,229)$... Of this sum, 5 percent literally went up in smoke in the form of fireworks, chances, incense and cigarettes. Another 20 percent was consumed in mescal [alcohol]... Each majordomo is required to contribute 1,051 pesos to a fund to finish the construction of a new church - 23 percent. Of the remaining 52 percent, 38 percent was spent food and 14 percent on meat." These percentages are generally comparable with the calculations of Dow (1974, pg. 26) for mayordomia expenditures in a village of Otomi (an indigenous group in the New Spain region): 49 percent for food, 20 percent for alcohol, 16 percent for fireworks, candles, and so on, and 11 percent for fuel and utensils. 
the gains in social prestige (Chance and Taylor, 1985). Serving as a mayordomo was "the most important means of acquiring prestige in the community" (Dewalt, 1975). Other households had to be induced by strong social (and sometimes physical) pressure to serve as mayordomos (Dewalt, 1975, pg. 90). Kuroda (1979) writes, "The customary expression of the people appointed to the offices of the higher category runs: "I myself did not want to accept this office, because it robs me of time and money, but the people chose me, so I will do my best. Why not?" The social pressure which drives people to accept communal service is so strong that the accomplishment of it is understood as a virtue."

Even in modern times, mayordomia households spend considerable amounts: Monaghan (1990, pg. 760) found that, in 1985, the mayordomia of the Virgen del Rosario in Santiago Nuyoó distributed "204,937 pesos worth of foodstuff" alone (\$46,425 in 2020 dollars). Greenberg (1981, pg. 149-152) finds that in Santiago Yaitepec, Oaxaca, in 1973, mayordomos spent an average of 4,566 pesos $(\$ 2,211$ in 2020 dollars). The food expenses alone would have been enough "to provide [the village] 13.5 days worth of food per capita annually" (Greenberg, 1981, pg. 149).

Anthropological accounts of Mexican saint day festivals have focused on understanding the puzzling persistence of the system. Dewalt (1979, pg. 201) noted that "poor peasants spend considerable time and money sponsoring fiestas to honor the saints", constituting "what appears to be economically irrational behavior". ${ }^{11}$ They have proposed at least two main reasons for the persistence and importance of the mayordomia system (Chance and Taylor, 1985). First, serving as a mayordomo was a costly signal of religiosity and wealth to the community (Monaghan, 1990, Chance and Taylor, 1985). In the view of some anthropologists, serving as a mayordomo was a form of "conspicuous consumption" that allowed households to gain community respect (Dewalt, 1979). Second, due to the rotating nature of the mayordomia system, anthropologists argued that the system also served an important redistributive role within the community (Greenberg, 1981, Monaghan, 1990, Rosales Martínez et al., 2020). (The view that serving as a mayordomo is a costly signal of religiosity, helping explain the system's persistence, concords with economics research on religious signaling discussed above.)

Saint day festivals continue to be significant in Mexican life today (Lastra et al.,

\footnotetext{
${ }^{11}$ Likewise, Chance and Taylor (1985, pg. 7) note that "a salient feature of modern fiesta systems in [central Mexico] is that the offices of the ritual celebrations are considered to be cargos, a great economic burden."
} 
2009, Rosales Martínez et al., 2020). In a wide array of localities, festivals continue to be elaborate and costly, following a "rigorous protocol... there must be vigils (velaciones), masses, ritual blessings and cleansings (limpias), processions, dances or dance dramas, music, fireworks, ritual meals, and the ritual handling of special objects and flowers" organized by the mayordomos and involve "the participation of men, women, and children of all ages" (Lastra et al., 2009, pg. 2).

\subsection{Exogeneity of Saint Day Festival Timing}

In Mexico, patron saints were typically established at the time of a town's founding or conquest by Spanish colonizers starting in the 1500s. Because the timing of saint day festivals (relative to agricultural seasons) is central to our analysis, we must consider how localities came to celebrate particular saints, with particular celebration dates. The origins of localities' patron saints are not cataloged systematically. We collect here a set of historical accounts of different places, keeping in mind whether localities appear to have chosen saints based on the timing of their festival date, and in particular whether they took into account a saint day's coincidence with planting or harvest. Evidence of such considerations would raise concerns about selection bias in our estimates.

In our review of the historical literature on Mexican localities' patron saints (e.g., Nutini, 1968, Nutini, 1976, Ragon, 2002), we have found little evidence that such timing considerations come into play. The most important focus appears to be on choosing the saint itself, with typically little mention of the festival date. Reasons given for the choice of particular saints are typically orthogonal to calendar timing. Saints were often chosen based on similarities with local indigenous gods, to facilitate conversions to Catholicism (Nutini, 1968). For example, the village of San Juan Tianguismanalco was originally associated with the cult of the Aztec god Tezcatlipoca. The village was assigned the patron saint Saint John the Apostle given that this saint and Tezcatlipoca both represented youth (Nutini, 1976). In other cases, localities were assigned a patron saint based on salient characteristics of their community (Ragon, 2002).

One category of explanation for the choice of saints does involve consideration of the date of the festival celebration. In some localities, Spanish conquerors chose saints whose festival date coincided with key dates in the Spanish conquest of or arrival in the locality. Many cities in Mexico take their saints on the basis of the saint whose feast is celebrated on the day the Spanish established or first visited 
the town (Ragon, 2002). For instance, the patron saint of Zacatecas was chosen to be the Virgin Mary because her feast day occurred on the arrival date there of conquistador Juan of Tolosa. Importantly, the reason for the choice of saint has to do with historical events at the time of conquest, with no obvious relationship with the timing of agricultural seasons.

Interestingly, some oral histories describe saint names being chosen at random (e.g., names physically pulled out of a bowl). Supposedly, random selection would allow saints to "choose" the locality, and that this would enhance the supernatural protection provided (Ragon, 2002). (We regret that this does not seem to have been a widespread enough practice to exploit for causal identification.)

Even if we believe that the choice of saints in the early history of towns (and the resulting coincidence of festival timing with agricultural seasons) is plausibly exogenous, one might worry that localities would seek to change their festival dates, once the consequences of their timing revealed themselves. There are indeed cases when communities changed their patron saints, but such cases appear to be rare. ${ }^{12}$ Patron saint celebrations are key components of a local community's history and culture. Perhaps unsurprisingly then, the few reported cases when communities changed their patron saint were motivated by a major negative shock, such as a flood, fire, or earthquake, and the switch was to a saint thought to protect against natural disasters (Ragon, 2002). ${ }^{13}$

Qualitative evidence on the exogeneity of festival dates is provided by Atkinson and Fowler (2014), who study festival timing and voter turnout. Atkinson and Fowler (2014) surveyed Catholic officials in Mexico about how their particular parish chose their patron saint. They found that "no respondent indicated that the time of year for the fiesta was considered in this decision. Rather, patron saints resulted from idiosyncratic events" and that in many cases "Spanish colonizers chose the patron saint of the community for arbitrary reasons" (Atkinson and Fowler, 2014, pg. 47). This survey evidence from Atkinson and Fowler (2014) provides additional evidence that the saint day festival date of a particular town

\footnotetext{
${ }^{12}$ Smith (1977) describes such changes in a town in neighboring Guatemala (ch. 12, footnote 1).

${ }^{13}$ However, in most cases following shocks, towns would often add additional patron saints to worship rather than replace the original saint (Ragon, 2002).
} 
is exogenous to local characteristics. ${ }^{14}$

In sum, we find no evidence in historical accounts that any locality's saint was chosen (or changed) so that its festival date would avoid or coincide with important agricultural periods. Instead, the focus was typically on the choice of the saint (based on a diversity of rationales). The festival date then follows the religious calendar set by the Vatican. In other cases where early Spanish conquerors sought to implement a specific festival date, the choice was based on coincidence with initial dates of conquest or settlement, rather than anything clearly related with agricultural seasons.

\section{Data}

\subsection{Data on Saint Day Festivals}

We assembled a dataset of saint day festival dates for Mexican municipalities from a variety of sources. First, we determined the patron saint for each municipality. An online data source, the Encyclopedia of Municipalities in Mexico (INAFED, 1988), provided information on the patron saint for $77.85 \%$ of municipalities. For the remaining municipalities, we (i) directly contacted municipalities by phone (13.97\% of municipalities) and (ii) conducted online searches, requiring at least two sources for each municipality $(7 \cdot 49 \%)$. In the phone calls, we focused on contacting municipal government officials, local churches, or schools. Overall, we were able to determine a patron saint for $99.3 \%$ of municipalities in Mexico. ${ }^{15}$ Appendix A.1 provides further detail, including source information.

Once we had determined the patron saint for (nearly all) municipalities, we then sought to ascertain the official (Vatican-prescribed) festival celebration date for that saint. We focus on the official timing rather than the date each municipality actually celebrates their festival, as the latter might be endogenous

\footnotetext{
${ }^{14}$ Atkinson and Fowler (2014, pg. 47) provide the translated account for one parish on how their patron saint was chosen: "The people of God were consulted with the approval of the bishop. Here in Tamaulipas, there is great devotion to Our Lady of Refuge because we were officially put under the patronage of Our Lady of Refuge by the Spanish royalty during colonial times."

${ }^{15}$ For two municipalities, officials reported that they do not celebrate a patron saint. For the other 16 municipalities, we were unsuccessful in determining a patron saint.
} 
to local conditions and outcomes. ${ }^{16}$ For nearly all municipalities (95.58\%), we used Roman Catholic Church documents to determine the official saint day. ${ }^{17}$ For saints that were not included in Catholic Church documents, we used other sources to determine the saint day (3.43\% of municipalities). This sub-sample of saints is comprised of two types of saints: (i) saints celebrated in other countries on specified official dates but that are not mentioned in Vatican documentation $(1.75 \%){ }^{18}$ and (ii) "local" saints: saints not recognized or celebrated outside of that municipality in Mexico (1.68\%). For our main analysis, we exclude this second subcategory ("local" saints) as the timing of their festivals is potentially endogenous; however, we show that our results are robust to their inclusion. ${ }^{19}$ In Appendix A.1, we provide more information on the saint day dataset construction and the sources we used.

Overall, we are able to determine the patron saint and the festival date for 95.12\% of municipalities in Mexico. The festival date is missing for $0.69 \%$ of municipalities for which we were unable to determine the patron saint from any source. The festival date is also missing for $4.19 \%$ of municipalities that celebrate "moving festivals" that do not have a fixed calendar date. ${ }^{20}$ Our primary sample for analysis in this paper excludes municipalities with missing festival dates, but our results are robust to various ways of treating these missing-date municipalities. ${ }^{21}$ Figure 1 provides a map of patron saint day festivals across

\footnotetext{
${ }^{16}$ Most municipalities in our sample (84\%) celebrate their saint day festival on exactly the date officially prescribed by the Vatican or other Roman Catholic authority outside of Mexico. Among those that do deviate from the official date, the median number of days of divergence from the official date is seven.

17In some cases, municipalities reported celebrating a saint that is derived from a Vaticanrecognized saint and celebrated on the same festival date, but the saint is referred to in the municipality by a different, local name. In these cases, we identified the relevant Vatican-recognized saint, and used the Vatican-prescribed festival date for that saint. We explain this process, the saints and municipalities affected, and the sources we used in detail in Appendix A.1.4.

${ }^{18}$ For instance, the Cristo Burgos festival originated in Burgos, Spain, and is celebrated there on September 14. The festival then spread to Mexico and other Catholic countries. One municipality in Mexico celebrates Cristo Burgos, and we assign it the festival date of September 14.

${ }^{19}$ In Appendix Table D7, we show that municipalities with local saints are similar on geographic characteristics to municipalities where the saint is non-local. Additionally, Appendix Table Dio shows the main results are robust to the inclusion of local saints in the sample.

${ }^{20}$ For example, the Sagrado Corazón de Jesús festival is celebrated on the Friday following the second Sunday of Pentecost - the seventh Sunday after Easter. Easter varies in timing year to year.

${ }^{21}$ In Appendix Table D6, we show that municipalities with missing dates have similar geographic characteristics to other municipalities. We also show the main results are very similar when we classify municipalities with missing festival dates either as having coinciding or non-coinciding festivals (see Appendix Tables D8 and D9).
} 
Mexico (including "local" saints).

In the former New Spain region of Mexico, $4.49 \%$ of municipalities have planting-coinciding festivals, $7.20 \%$ have harvest-coinciding festivals, for a total of $11.69 \%$ having agriculturally-coinciding festivals. ${ }^{22}$

Figure 1: Saint Day Festival Months - All of Mexico

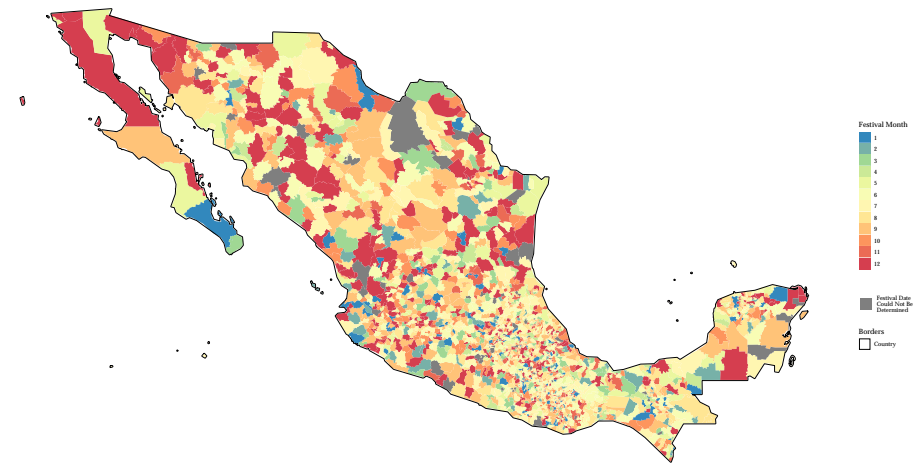

\begin{abstract}
Notes: The map presents the month that each municipality in Mexico celebrates its respective Catholic patron saint day festival. Municipalities where we were unable to determine the festival date are shaded in dark grey. See Appendix A.1 for more information on the construction of the festival date dataset.
\end{abstract}

\title{
4.2. Data on the New Spain Region of Mexico
}

Our primary analyses focus on a relatively homogeneous sample of municipalities in the former "New Spain" (Nueva España) region of Mexico. Municipalities in this region are nearly all suitable for growing maize, which simplifies the analysis by allowing us to focus on maize planting and harvest periods. Maize has been the primary staple crop in the region since pre-colonial times (Gibson, 1964). In other parts of Mexico outside of New Spain, there is more heterogeneity in both agricultural suitability and suitability for maize. Thus, the choice of primary crop outside New Spain could possibly reflect endogenous choices to focus on certain non-maize crops in periods closer to the present day. ${ }^{23}$ By focusing on an area that has been primarily maize-growing since pre-colonial times, we can sidestep

\footnotetext{
${ }^{22}$ In Mexico overall, the corresponding percentages are $6.31 \%, 7.94 \%$, and $14.25 \%$.

${ }^{23}$ The difference in agricultural suitability and in primary crops derives from differences in climate: New Spain is largely temperate and subtropical, while the north is mostly semi-arid and arid desert, while the southeast is tropical (Ricketts et al., 1999).
} 
concerns that a locality's primary crop may be endogeneous to the economic development process.

New Spain is also distinct from other parts of Mexico on other dimensions relevant for our study. It was the first part of Mexico to be conquered and settled by the Spanish, and was the main administrative unit during early colonial history. The area thus has the longest history of colonial influence in Mexico, which may make Catholic religious traditions like saint day festivals comparatively more important in this region. The historical accounts we cite above about the importance of festivals and the mayordomia system all refer to localities in New Spain. Today, saint day festivals remain more important in the former New Spain than in the rest of Mexico (Lastra et al., 2009). Municipalities in New Spain are also distinctive in being much smaller in land area and more densely populated compared to municipalities in the rest of the country. ${ }^{24}$ Town-based community celebrations such as saint day festivals may have more impact in the more compact, denser populations of New Spain.

Figure 2 presents a map of the borders of the New Spain region in Mexico. We use the definition of New Spain as of 1786, as in Map 8 of Gerhard (1993). Figure B1 presents a map of festival months across New Spain municipalities. ${ }^{25}$

\subsection{Data on Crop Planting and Harvest Dates (FAO)}

We focus on the planting and harvest cycle for maize, as maize is and has historically been the most important crop in New Spain. Maize is native to the area, and remains the crop with the highest potential caloric yield in the region, based on Caloric Suitability Index (CSI) measures (Galor and Ozak, 2016). ${ }^{26}$

We obtained data on the optimal local planting and harvest dates for maize from the Global Agro-Ecological Zones (GAEZ) project of the Food and Agricul-

\footnotetext{
${ }^{24} \mathrm{New}$ Spain municipalities have mean land area of 336.1 square kilometers, compared with non-New Spain municipalities' mean of 2,385.9 square kilometers. Mean population density is 308.6 persons per square kilometer in New Spain municipalities vs. 98.o persons per square kilometer in non-New Spain municipalities. Municipalities in New Spain comprise $60 \%$ of the Mexican population (authors' calculations from the 2010 Mexican Census).

${ }^{25}$ In Section 6, we show that our results are robust to considering the sample of all Mexican municipalities for which we have festival dates.

${ }^{26}$ The CSI measures the potential caloric yield per hectare per year under rain-fed agriculture and low level of inputs for a variety of crops. For $77.54 \%$ of New Spain municipalities, maize is the highest caloric-yielding (max CSI) crop. Other New Spain municipalities have the following max CSI crops: wetland rice (9.23\% of municipalities), foxtail millet $(5 \cdot 70 \%)$, and wheat $(7 \cdot 52 \%)$. Foxtail millet, wetland rice, and wheat are not native to the Americas pre-1500 CE.
} 
Figure 2: Administrative Borders and New Spain Region of Mexico

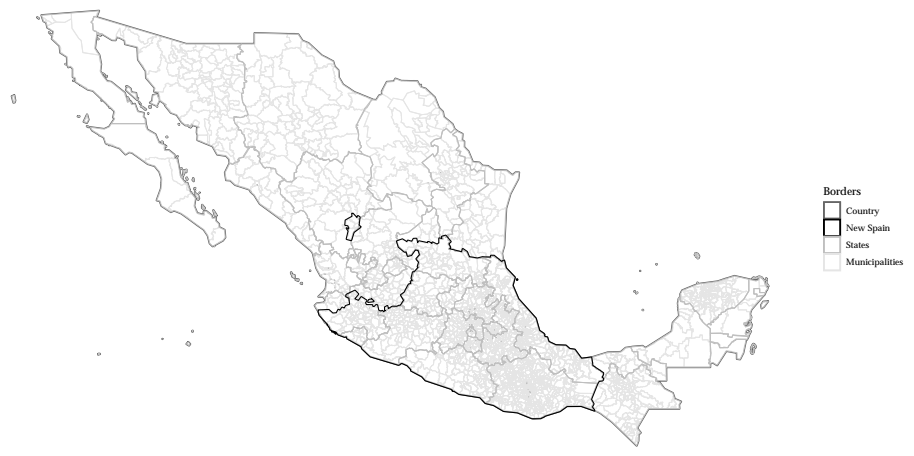

Notes: Administrative borders of Mexico in shades of gray: country, state, and municipality borders. In black: border of the New Spain region in 1786 (Gerhard, 1993).

ture Organization (FAO). These data provide estimates of maize growth cycles at the grid-cell level $\left(5^{\prime} \times 5^{\prime}\right.$, approximately $\left.100 \mathrm{~km}^{2}\right)$ under rain-fed or irrigated agriculture, and under three alternative levels of inputs (low, medium, and high). The estimates incorporate the effect of moisture and temperature on the growth of the crop, the disease environment, as well as climate-related pest, "workability", and disease constraints. In our analyses, we use estimates of maize planting and harvest dates based on agro-climatic growth cycles under rain-fed agriculture and low levels of inputs. We use these restrictions to reduce potential concerns that the irrigation method and level of agricultural inputs reflect endogenous choices that could be potentially correlated with economic development.

For each municipality, we take the average optimal planting date across grid cells in a municipality as the optimal planting date. We then construct the optimal harvest date in each municipality by taking the average optimal planting date and adding the average number of days until harvest across grid cells within each municipality. ${ }^{27}$ Some municipalities are not suitable for maize, and we exclude these municipalities from the main analysis as we are not able to determine optimal planting and harvest dates for these municipalities. ${ }^{28}$

\footnotetext{
${ }^{27}$ We have confirmed empirically that these statistics derived from GAEZ data do predict the timing of actual agricultural activity. Using data on the timing of maize harvesting from the Servicio de Información Agroalimentaria y Pesquera (SIAP), we show in Appendix Figure C1 that our constructed optimal harvest month strongly predicts observed maize harvest timing across Mexico.

${ }^{28}$ This maize suitability restriction affects $0.53 \%$ of municipalities in the New Spain region of Mexico, and $2.07 \%$ of municipalities in Mexico as a whole.
} 
One might worry that there might not be substantial variability in planting and harvest calendar periods within our focus area, New Spain. If planting and harvest tend to occur in similar months of the year across municipalities (e.g., all plantings in June, all harvests in October), then interpretation of any effects of coinciding festivals might be confounded by other regular events that happen to occur in the same months (e.g., elections, union contract negotiations, peak industrial production periods, etc.). It would be difficult to determine whether the true cause of any effects we find are due to coincidence of festivals with the agricultural planting and harvest periods, or due to coincidence with other regular events that tend to occur in the same calendar months.

As it turns out, this issue is less of a concern in this setting because optimal planting and harvest calendar months show considerable variation across municipalities. Figure B2 presents a map of the optimal maize planting month in New Spain according to the GAEZ estimates, while Figure B3 displays a corresponding map of the optimal maize harvest month. ${ }^{29}$ The maps highlight the large amount of spatial variation in the optimal maize planting and harvest periods. $^{30}$ This variation allows us to include fixed effects for detailed calendar periods in our regressions (in practice, for 52 calendar weeks), which controls for any confounders associated with particular weeks on the calendar.

We then use the data on festival dates across Mexican municipalities detailed in Section 4.I to construct a measure of the coincidence of timing of a municipality's saint day festival with its planting and harvest periods. Figure 3 presents a map of New Spain municipalities and whether they have agriculturally-coinciding festivals. We define agriculturally coinciding as an indicator variable equal to 1 if the saint day festival in a municipality occurs either within o to 30 days before the optimal maize planting date or o to 30 days after the optimal maize harvest

\footnotetext{
${ }^{29}$ In some regions of Mexico, maize production is split into two seasons: a primary season that accounts for approximately 75 percent of total production (usually with planting occurring spring/summer), and a shorter secondary season (usually with planting occurring in the fall/winter) (USDA, 2017). The FAO GAEZ planting and harvest cycle estimates are for the primary season for each grid cell (Fischer et al., 2012). We focus on the primary maize season because it accounts for the majority of production.

${ }^{30}$ Appendix Figures B8 and B9 present the equivalent maps for maize planting and harvest dates for all of Mexico.
} 
date. ${ }^{31}$

Figure 3: Agriculturally-Coinciding Festivals - New Spain Region of Mexico

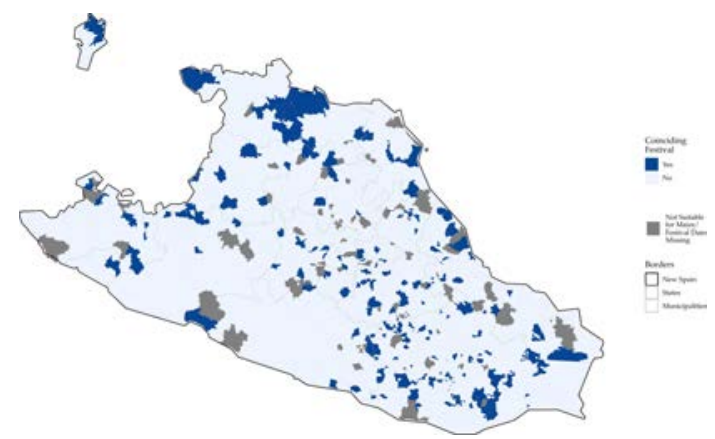

\begin{abstract}
Notes: Coinciding Festival is equal to "Yes" if the saint day festival in a municipality occurs either o to 30 days prior to the optimal maize planting date or o to 30 days after the optimal maize harvest date for a municipality using FAO GAEZ data, and "No" otherwise for each municipality in the New Spain region of Mexico. Municipalities where we were unable to determine the festival date or are unsuitable for maize are shaded in dark grey.
\end{abstract}

\title{
4.4. Data Sources for Development Outcomes
}

Our primary outcome variables (household income and an index of economic development) are at the municipality level, and come from the 2010 Censo de Población y Vivienda (Population Census henceforth) from Mexico's National Institute of Statistics and Geography (INEGI). This census interviewed households comprising over 106 million inhabitants across Mexico about their economic well-being, labor supply, asset ownership, and education. We also use municipality-level data on agricultural production from the Servicio de Información Agroalimentaria $y$ Pesquera (SIAP) in our analysis of maize productivity. See Appendix A for further details.

\subsection{Data on Additional Covariates}

We assemble a set of municipality characteristics to use in balance tests and as control variables. We obtain temperature and precipitation data from the Global Climate Database (Hijmans et al., 2005) and land suitability measures from the

\footnotetext{
${ }^{31}$ Figure $B_{4}$ presents a map of the number of days between the saint day festival date and the optimal maize planting date and Figure B5 presents a map of the days between the saint day festival date and optimal maize harvest date in New Spain. Figures B10 and B11 present the equivalent maps for the distance between the saint day festival and maize planting and maize harvest dates for all of Mexico.
} 
Atlas of the Biosphere (Ramankutty et al., 2002). We combine these datasets with the administrative shapefile of municipality boundaries from INEGI to construct municipality-level covariates. Additionally, we use the municipality shapefile to construct municipality land area and municipality-centroid latitude and longitude. See Appendix A for further detail.

We obtain historical measures of population density and climate from Sellers and Alix-Garcia (2018), which contains various data on the colonial governorships of New Spain, including records from Spanish administrators on the number of individuals paying tribute to the Spanish Crown. ${ }^{32}$ Drought severity data in the early colonial era are from the North American Drought Atlas (Cook and Krusic, 2004). Drought severity is an important predictor of the dramatic decline in tributary population during the early colonial era and subsequent development (Sellers and Alix-Garcia, 2018). Population data for 1900 (used in Section 7.2) are from INEGI's Historical Archive of Localities.

\section{Empirical Strategy}

We estimate the effects of agriculturally-coinciding festivals using the following regression equation:

$$
y_{m}=\alpha_{s(m)}+\beta \text { Festival Coincides with Planting or Harvest }{ }_{m}+\mathbf{X}_{\mathbf{m}}^{\prime} \mathbf{B}+\epsilon_{m}
$$

where $m$ indexes municipalities; $y_{m}$ is our outcome of interest; $s(m)$ is a function mapping municipalities to Mexican states; $\alpha_{s(m)}$ represent state fixed effects to account for all time-invariant differences across states, such as geography or cultural factors that do not vary over time; 33 Festival Coincides with Planting or Harvest ${ }_{m}$ is an indicator variable equal to $\mathcal{I}$ if the saint day festival in municipality $m$ occurs $o$ to 30 days before the optimal maize planting date or o to 30 days after the optimal

\footnotetext{
$3^{32}$ There are no other proxies for population for the colonial era. See Sellers and Alix-Garcia (2018) on how the tributary data are converted to population measures.

${ }^{33}$ Across Mexico, there are 32 states. In the New Spain region of Mexico, there are 13 different states. Section 6.3.1 shows the results using the full sample of Mexican municipalities.
} 
maize harvest date; ${ }^{34} \mathbf{X}_{\mathrm{m}}$ is a vector of controls that includes fixed effects for the planting calendar month, fixed effects for the harvest calendar month, 35 fixed effects for the festival calendar week, and controls for geographic, climatic, and historical characteristics for municipality $m$; and $\epsilon_{m}$ is the error term of municipality $m$. For municipality-level outcomes, we present robust standard errors. For individual-level outcomes, we cluster standard errors at the municipality level. We also show that our results are robust to spatial autocorrelation; we present all main results with Conley (1999) standard errors in brackets using a $100 \mathrm{~km}$ cut-off window. In this setting, the Conley (1999) standard errors are very similar to the robust standard errors, indicating that the agricultural coincidence of festivals does not show high spatial correlation.

The coefficient of interest is $\beta$, the effect of having festivals coincide with planting or harvest. We hypothesize that $\beta<0$ when examining long-run economic development outcomes.

The main identifying assumption is that $E\left[\epsilon_{m} \mid\right.$ Festival Coincides with Planting or Harvest $\left._{m}\right]=E\left[\epsilon_{m}\right]=0$. That is, whether a municipality's saint day festival is agriculturally-coinciding is exogenous to features of the municipality that could also affect economic development. To be specific, for example, it should not be the case that municipalities with worse determinants of agricultural productivity (e.g., lower average rainfall, steeper slope of the land, etc.) are more likely to have agriculturally-coinciding festivals.

To increase the plausibility of the identifying assumption, we make a number of analytical choices to increase confidence that the independent variable of interest (the indicator for agriculturally-coinciding festivals) is plausibly exogenous. We also provide empirical tests supporting the validity of this identifying assumption.

First, we seek to address the concern that - even if the identity of their patron saints may be considered exogenous - municipalities may choose (endogenously) to celebrate their saints on dates that do not coincide with planting and harvest

\footnotetext{
34We also show results separately for festivals that coincide with planting and festivals that coincide with harvest in Section 6.2. When we show results separately, we include p-values for testing differences across coefficients for festivals that coincide with planting and festivals that coincide with harvest; in all cases, we fail to reject the null hypotheses that the coefficients are the same. Additionally, we explore the sensitivity of the results to the definition of the 30-day windows in Appendix $C$ and show that the results are robust to various windows prior to planting and following harvest.

35 There are 22 planting and calendar month fixed effects ( 11 for planting and 11 for harvest; one calendar month in each set is the excluded category.)
} 
periods. To address this concern, we take advantage of the fact that the global Catholic Church prescribes official celebration dates for Catholic saints. When constructing the indicator variable for agriculturally-coinciding festivals, instead of using the date when the municipality actually celebrates the saint, we use the official celebration date defined in the Vatican's calendar for the municipality's patron saint (see Section 4.1). As it turns out, the vast majority of municipalities follow the official date, and deviations that do occur are small (see Section 4.1). It is difficult to imagine that the Vatican sets official saint celebration dates thinking of the agricultural-coincidence of those dates in Mexican municipalities. Therefore, our use of the Vatican dates removes concerns about the potential endogeneity of celebrated dates. ${ }^{36}$

Second, one might be concerned about endogeneity of the dates of harvest and planting in a locality. In particular, a worry would be that localities with coinciding festivals would shift their planting and harvest work to other periods, away from the festival date.Therefore, to determine the timing of agricultural planting and harvest periods, we use estimates from the FAO GAEZ data based on geographic and climate characteristics rather than the dates when households in a municipality perform planting and harvesting. 37

Overall, using these measures from objective data for festival dates and agricultural planting and harvest periods increases confidence that the coincidence between festivals and agricultural seasons is plausibly exogenous to other important municipality characteristics that might affect development.

In addition to these analytical choices, we also provide direct empirical evidence on the validity of the identification assumption. A concern with equation (1) is that saint day festivals could have been originally selected (or subsequently changed) to avoid the agricultural season in some municipalities, but not in

\footnotetext{
${ }^{36}$ This approach is analogous to an IV approach in which the official date instruments for the celebrated date, but where we just focus on the "reduced form" effect of the instrument on the ultimate outcome of interest. Using actual instead of Vatican-prescribed festival dates would probably bias our estimated effects of coinciding festivals towards zero. Localities that moved their festivals to avoid coincidence with optimal planting and harvest times would likely be positively selected with respect to determinants of agricultural productivity, and we would be misclassifying some of these as having non-coinciding instead of coinciding festivals.

37If households do shift their actual planting and harvest work away from festival times, and we determined festival-coincidence using actual planting and harvest dates rather than FAO GAEZ dates, we could erroneously categorize localities with coinciding festivals as non-coinciding. Planting and harvesting away from the optimal times should harm agricultural productivity, so such errors would attenuate our estimates of the effects of coinciding festivals towards zero.
} 
others. If this strategic selection were occurring, there should be a tendency for festivals coinciding with planting or harvest periods to be less frequent in the data compared to other time periods.

To test whether this is the case, we construct a dataset at the municipality-date level, with 365 observations per municipality (one for each calendar date). The dependent variable, Festival Date Dt $_{m}$, is an indicator equal to one if municipality $m$ 's festival occurs on date $t$, and is zero otherwise. We then test whether municipalities are less likely to have festival days that coincide with planting and harvest months in the data by estimating the following regression equation:

$$
\text { Festival Date }_{m t s w}=\beta \text { Planting or Harvest Month }{ }_{m t}+\alpha_{s}+\theta_{w}+\phi_{w s}+\epsilon_{m t}
$$

where $m$ indexes municipalities, $t$ indexes calendar dates, $s$ indexes states, and $w$ indexes weeks of the year; Planting or Harvest Month ${ }_{m t}$ is an indicator equal to one if calendar date $t$ is either o to 30 days prior to the optimal maize planting date or o to 30 days after the optimal maize harvest date for municipality $m$; $\alpha_{s}$ represent state fixed effects; $\theta_{w}$ represent week-of-the-year fixed effects to account for time-invariant differences across calendar weeks in the propensity to have saint days according to the Roman Catholic Church calendar; $\phi_{w s}$ are week-by-state fixed effects to allow festival calendar week effects to vary by state; and $\epsilon_{m t}$ is the error term of municipality $m$ for date $t$. We cluster standard errors by municipality. If saint day festivals were strategically chosen taking into account agricultural planting and harvest times, then we would expect that $\beta \neq 0$. However, if the saint day festivals were determined without taking into account the timing of the agricultural season, then we would expect that $\beta=0$.

Table 1 presents the results from estimating equation (2). (Coefficients are multiplied by 100 to improve visibility.) Columns 1-2 present results examining whether the festival date coincides with either the planting or harvest month, while columns 3-4 show results separately for coinciding with planting and coinciding with harvest. Coefficient estimates are consistently small in magnitude and are not statistically significantly different from zero at conventional levels. Results are not sensitive to inclusion of week-by-state fixed effects. Across all columns, there is no evidence that festivals are more or less likely to coincide with planting or harvest months. Instead, the estimates suggest that festival dates occur throughout the calendar in a way that is consistent with festival days not 
being assigned strategically to avoid or coincide with planting and harvest. ${ }^{38}$ This evidence supports the assumption that, conditional on calendar week fixed effects, the agricultural-coincidence of festival dates is exogenous. 39

Table 1: Relationship Between Festival, Planting, and Harvest Months

\begin{tabular}{|c|c|c|c|c|}
\hline & \multicolumn{4}{|c|}{$\begin{array}{c}\text { Dependent Variable: } \\
\text { Festival Date }\end{array}$} \\
\hline & (1) & (2) & (3) & (4) \\
\hline Maize Planting or Harvest Month & $\begin{array}{c}-0.020 \\
(0.017) \\
{[0.017]}\end{array}$ & $\begin{array}{c}-0.013 \\
(0.018) \\
{[0.018]}\end{array}$ & & \\
\hline Maize Planting Month & & & $\begin{array}{c}-0.020 \\
(0.020) \\
{[0.021]}\end{array}$ & $\begin{array}{c}-0.009 \\
(0.022) \\
{[0.022]}\end{array}$ \\
\hline Maize Harvest Month & & & $\begin{array}{c}-0.021 \\
(0.027) \\
{[0.028]}\end{array}$ & $\begin{array}{c}-0.018 \\
(0.028) \\
{[0.028]}\end{array}$ \\
\hline Calendar Week Fixed Effects & $\mathrm{Y}$ & $\mathrm{N}$ & $\mathrm{Y}$ & $\mathrm{N}$ \\
\hline Week by State Fixed Effects & $\mathrm{N}$ & $\mathrm{Y}$ & $\mathrm{N}$ & $\mathrm{Y}$ \\
\hline Observations & 583,038 & 583,038 & 583,038 & 583,038 \\
\hline Clusters & 1,593 & 1,593 & 1,593 & 1,593 \\
\hline Adjusted R2 & 0.004 & 0.004 & 0.004 & 0.004 \\
\hline Mean Dep. Var. & 0.273 & 0.273 & 0.273 & 0.273 \\
\hline $\begin{array}{l}\text { Notes: Observations are at the municip } \\
\text { region of Mexico for which we have fest } \\
\text { are presented in parentheses and Conle } \\
\text { window are presented in brackets. For } \\
\text { by } 100 \text {. Maize Planting or Harvest Mont } \\
\text { to } 30 \text { days prior to the optimal maize pl } \\
\text { date for a municipality using FAO GAE } \\
\text { to } 1 \text { if a date falls within } 0 \text { to } 30 \text { days } p \\
\text { using FAO GAEZ data. Maize Harvest } M \\
0 \text { to } 30 \text { days after the optimal maize harv } \\
\text { Week Fixed Effects are indicator variables } \\
\text { effects). Week by State Fixed Effects are ir } \\
\text { fixed effects. }{ }^{*} p<0.10,{ }^{* *} p<0.05,{ }^{* * * *} p\end{array}$ & $\begin{array}{l}\text { ty-calendar } \\
\text { i data. Stan } \\
\text { (1999) stanc } \\
\text { e of interpr } \\
\text { S an indicat } \\
\text { ting date o } \\
\text { data. Maize } \\
\text { ot to the op } \\
\text { th is an ind } \\
\text { t date for a } \\
\text { each separ } \\
\text { raction tern } \\
0.01 \text {. }\end{array}$ & $\begin{array}{l}\text { e level for n } \\
\text { d errors clus } \\
\text { lerrors calc } \\
\text { ion, we mul } \\
\text { variable equ } \\
\text { o } 30 \text { days a } \\
\text { nting Month } \\
\text { al maize pl } \\
\text { or variable } \\
\text { nicipality us } \\
7 \text {-day perio }\end{array}$ & $\begin{array}{l}\text { nicipalities } \\
\text { red at the n } \\
\text { ated using } \\
\text { ly all regre } \\
\text { to } 1 \text { if a d } \\
\text { r the optim } \\
\text { san indicat } \\
\text { ting date fo } \\
\text { ual to } 1 \text { if a } \\
\text { in FAO GAI } \\
\text { in the calen }\end{array}$ & $\begin{array}{l}\text { the New Spain } \\
\text { icipality leve } \\
00 \text { km cut-of } \\
\text { on coefficient } \\
\text { falls within } \\
\text { maize harves } \\
\text { variable equa } \\
\text { municipality } \\
\text { te falls withil } \\
\text { data. Calenda } \\
\text { year } 52 \text { fixec }\end{array}$ \\
\hline
\end{tabular}

A second concern with equation ( 1 ) is that if festivals were determined in some way dependent on characteristics that might matter for economic development - such as geography and climate - then municipalities with agriculturallycoinciding festivals might differ from others. If this were the case, then the estimates from equation (1) for our independent variable of interest would not be

${ }^{38}$ Also of note, the adjusted R-squared in each regression is very low, even when the full set of week-by-state fixed effects are included in the regression. This indicates that it is difficult to predict whether a municipality's festival would happen on a particular date on the basis of week-withinstate variation (and whether a period is a planting or harvest period).

${ }^{39}$ In Appendix Table D1, we conduct a similar analysis for municipalities in all of Mexico. Results are very similar, and lead to the same conclusion: there is little evidence that festivals tend to be more or less likely in planting or harvest months, after conditioning on calendar week fixed effects. 
causal and would instead be capturing impacts of these other differences between municipalities.

To examine whether this is the case, we estimate equation (1) and have the outcome $y_{m}$ be a series of geographic, climatic, and historical characteristics that might affect development. Figure 4 presents the estimates for this exercise. The estimates suggest that, conditional on fixed effects for state, planting month, harvest month, and festival week, municipalities that happen to have festivals coincide with planting or harvest are generally not significantly different from municipalities where this is not the case for a number of characteristics that are potentially important for economic development. ${ }^{40}$ These findings provide additional support for taking the coincidence of festival dates with planting or harvest seasons as exogenous.

\section{Results}

\subsection{Impacts of Agriculturally-Coinciding Festivals}

We now present regression estimates of the impact of agriculturally-coinciding festivals on long-run economic development. We use data from the 2010 Population Census as outcome variables in estimating equation (1). To discipline the analysis and avoid data mining and specification search concerns for multiple outcomes, we focus on two main outcomes. The first is simply the log of mean household income in the municipality. The second is an index we construct using all questions in the census related to economic development. Log household income is one component of the index, but other components are a wide range of municipality characteristics related to employment, educational attainment (by gender and for various age groups), and asset ownership. The index is the first principal component of these variables. Further detail is in Appendix A.

Table 2 presents the estimates for equation (1) for log household income (Panel A) and for the index of economic development (Panel B) as the dependent variables. Column (1) does not include state fixed effects, while columns

\footnotetext{
${ }^{40}$ We present the estimates in table form in Table D2. We do find that municipalities with coinciding festivals are more likely to be suitable for maize and less likely to have experienced drought in 1545 (both statistically significant at the $10 \%$ level). These preexisting differences should improve the long-run economic development prospects of places with agriculturally-coinciding festivals, suggesting that our estimates may be lower bounds (in absolute value) of the true (negative) effects of coinciding festivals on economic development. In subsequent regression tables we show estimates without and with these and other controls. Results are always robust to their inclusion or exclusion.
} 
Figure 4: Municipality Characteristics and Coinciding Festivals

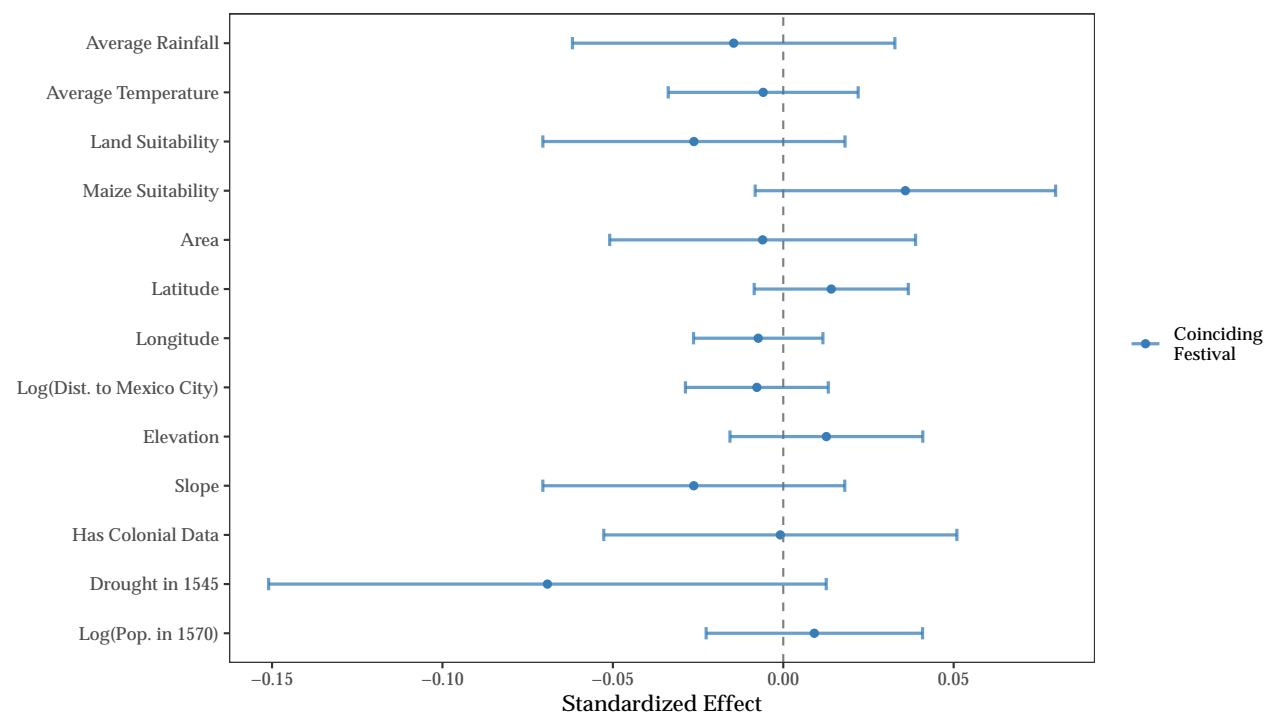

Notes: Data are from the 2010 Mexico Population Census for New Spain region of Mexico. Colonial drought and population density data are from Sellers and Alix-Garcia (2018). The figure presents the estimated standardized coefficients and respective $95 \%$ confidence intervals from estimating equation (1) on various municipality characteristics (denoted on the y-axis), conditional on state fixed effects, planting-month and harvest-month fixed effects, and festival-week fixed effects. Coinciding Festival is an indicator variable equal to 1 if the saint day festival in a municipality occurs either within $0-30$ days prior to the optimal maize planting date or o-30 days after the optimal maize harvest date for a municipality using FAO GAEZ data, and o otherwise. Note that we do not have colonial characteristics for all observations in our sample; therefore, we also show results for Has Colonial Characteristics, an indicator equal to 1 if a municipality is not missing colonial characteristics.

(2)-(5) do. Columns (3) and (4) include additional geographic and historical controls, respectively. Column (5) includes planting-month, harvest-month, and festival-week fixed effects to account for potential direct (time-invariant) impacts of having planting or harvest occur at different points in the calendar, or for having a festival occur in a particular calendar week. The estimates presented in Table 2 show that having an agriculturally-coinciding festival is associated with significantly lower levels of economic development. Point estimates are not highly sensitive to the set of control variables and fixed effects included in the regression. Conley (1999) standard errors presented in brackets are very similar to the robust standard errors, highlighting that that festival coincidence with planting and harvest periods is not substantially spatially correlated. In the most inclusive specification, column 5 , such festivals lead to roughly $20 \%$ lower household income, and 0.13-standard-deviations lower index of economic 
development.

While these negative effects are large, it would have been difficult for communities to recognize that agriculturally-coinciding festivals were hindering their economic development. Because these festivals have been celebrated for centuries, the current differences in income have likely compounded over time from small but persistent differences in annual growth rates. If annual economic growth in localities with coinciding festivals were just $0.1 \%$ lower on average, this difference would probably not be noticeable to residents from one year to the next. ${ }^{41}$ But an annual growth difference of this size would compound over 200 years to $20 \%$ lower income in municipalities with coinciding festivals.

To explore what index sub-components are driving impacts on the overall index of economic development, we present estimated effects for each individual index component in Figure 5. For the vast majority of the sub-components, the coefficient on coinciding festivals is negative and statistically significantly different from zero. Having a coinciding festival is associated with lower household income, literacy, employment, and education. The results in Figure 5 reveal that the negative impacts of agriculturally-coinciding festivals are evident on a range of measures of development, beyond income levels.

How much lower is mean household income in the former New Spain region overall due to coinciding festivals? We calculate the following counterfactual. We ask what our estimates would imply about aggregate GDP in the region if all municipalities with coinciding festivals instead had non-coinciding festivals. In each municipality with a coinciding festival, we increase 2010 municipality aggregate income by $20.6 \%$, and population by $21.0 \%$ (the percentages implied by our regression estimates of the impact of coinciding festivals). We then calculate counterfactual total income in the former New Spain, accounting for each municipality's counterfactual population when aggregating, and compare this with the region's actual 2010 aggregate income. Our estimates imply that aggregate GDP in the former New Spain region of Mexico is $4.2 \%$ lower today due to coinciding festivals.

We also examine whether impacts are similar for festivals that coincide with planting and festivals that coincide with harvest. Table $\mathrm{D}_{4}$ presents the results of estimating equation (1) with separate indicators for festivals coinciding with

\footnotetext{
${ }^{41}$ For comparison, Wagner (2021) estimates that one extra holiday per year causes a decrease of $0.1 \%$ in economic growth.
} 
Table 2: Impact of Agriculturally-Coinciding Festivals on Development Outcomes

\begin{tabular}{|c|c|c|c|c|c|}
\hline & \multicolumn{5}{|c|}{$\begin{array}{l}\text { Dependent Variable: } \\
\text { Panel A: Log HH Income }\end{array}$} \\
\hline & $(1)$ & $(2)$ & (3) & $(4)$ & (5) \\
\hline Festival Coincides with Maize Planting or Harvest & $\begin{array}{c}-0.275^{* * *} \\
(0.099) \\
{[0.107]}\end{array}$ & $\begin{array}{c}-0.204^{* *} \\
(0.080) \\
{[0.080]}\end{array}$ & $\begin{array}{c}-0.251^{* * *} \\
(0.071) \\
{[0.082]}\end{array}$ & $\begin{array}{c}-0.255^{* * *} \\
(0.070) \\
{[0.079]}\end{array}$ & $\begin{array}{c}-0.206^{* * *} \\
(0.077) \\
{[0.075]}\end{array}$ \\
\hline $\begin{array}{l}\text { State Fixed Effects } \\
\text { Geography Controls } \\
\text { Colonial Controls } \\
\text { Planting-Month Fixed Effects } \\
\text { Harvest-Month Fixed Effects } \\
\text { Festival-Week Fixed Effects }\end{array}$ & $\begin{array}{l}\mathrm{N} \\
\mathrm{N} \\
\mathrm{N} \\
\mathrm{N} \\
\mathrm{N} \\
\mathrm{N}\end{array}$ & $\begin{array}{l}\mathrm{Y} \\
\mathrm{N} \\
\mathrm{N} \\
\mathrm{N} \\
\mathrm{N} \\
\mathrm{N}\end{array}$ & $\begin{array}{l}\mathrm{Y} \\
\mathrm{Y} \\
\mathrm{N} \\
\mathrm{N} \\
\mathrm{N} \\
\mathrm{N}\end{array}$ & $\begin{array}{l}\mathrm{Y} \\
\mathrm{Y} \\
\mathrm{Y} \\
\mathrm{N} \\
\mathrm{N} \\
\mathrm{N}\end{array}$ & $\begin{array}{l}\mathrm{Y} \\
\mathrm{Y} \\
\mathrm{Y} \\
\mathrm{Y} \\
\mathrm{Y} \\
\mathrm{Y}\end{array}$ \\
\hline $\begin{array}{l}\text { Observations } \\
\text { Adjusted R2 } \\
\text { Mean Dep. Var. } \\
\text { SD Dep. Var. }\end{array}$ & $\begin{array}{l}1,593 \\
0.004 \\
3.234 \\
1.330\end{array}$ & $\begin{array}{l}1,593 \\
0.347 \\
3.234 \\
1.330\end{array}$ & $\begin{array}{l}1,593 \\
0.538 \\
3.234 \\
1.330\end{array}$ & $\begin{array}{l}1,593 \\
0.543 \\
3.234 \\
1.330\end{array}$ & $\begin{array}{l}1,593 \\
0.567 \\
3.234 \\
1.330\end{array}$ \\
\hline \multirow{2}{*}{ SD Dep. Var. } & \multicolumn{5}{|c|}{ Dependent Variable: } \\
\hline & $(1)$ & (2) & (3) & (4) & $(5)$ \\
\hline Festival Coincides with Maize Planting or Harvest & $\begin{array}{c}-0.695^{* *} \\
(0.300) \\
{[0.342]}\end{array}$ & $\begin{array}{c}-0.422^{*} \\
(0.240) \\
{[0.252]}\end{array}$ & $\begin{array}{c}-0.593^{* * *} \\
(0.209) \\
{[0.226]}\end{array}$ & $\begin{array}{c}-0.613^{* * *} \\
(0.208) \\
{[0.220]}\end{array}$ & $\begin{array}{c}-0.537^{* *} \\
(0.224) \\
{[0.190]}\end{array}$ \\
\hline State Fixed Effects & $\mathrm{N}$ & $\mathrm{Y}$ & Y & Y & $\mathrm{Y}$ \\
\hline Geography Controls & $\mathrm{N}$ & $\mathrm{N}$ & $\mathrm{Y}$ & $\mathrm{Y}$ & $\mathrm{Y}$ \\
\hline Colonial Controls & $\mathrm{N}$ & $\mathrm{N}$ & $\mathrm{N}$ & $\mathrm{Y}$ & $\mathrm{Y}$ \\
\hline Planting-Month Fixed Effects & $\mathrm{N}$ & $\mathrm{N}$ & $\mathrm{N}$ & $\mathrm{N}$ & $\mathrm{Y}$ \\
\hline Harvest-Month Fixed Effects & $\mathrm{N}$ & $\mathrm{N}$ & $\mathrm{N}$ & $\mathrm{N}$ & $\mathrm{Y}$ \\
\hline Festival-Week Fixed Effects & $\mathrm{N}$ & $\mathrm{N}$ & $\mathrm{N}$ & $\mathrm{N}$ & $\mathrm{Y}$ \\
\hline Observations & 1,593 & 1,593 & 1,593 & 1,593 & 1,593 \\
\hline Adjusted R2 & 0.002 & 0.348 & 0.566 & 0.572 & 0.597 \\
\hline Mean Dep. Var. & -0.589 & -0.589 & -0.589 & -0.589 & -0.589 \\
\hline SD Dep. Var. & 4.039 & 4.039 & 4.039 & 4.039 & 4.039 \\
\hline
\end{tabular}

Notes: Data are from the 2010 Mexico Population Census. Observations are municipalities in the New Spain region of Mexico. Robust standard errors are presented in parentheses and Conley (1999) standard errors calculated using a 100 $\mathrm{km}$ cut-off window are presented in brackets. Index of Economic Development is the first principal component index of a number of development outcomes in the census for a municipality (see Appendix A). Festival Coincides with Maize Planting or Harvest is an indicator variable equal to 1 if the saint day festival in a municipality occurs either 0 to 30 days prior to the optimal maize planting date or 0 to 30 days after the optimal maize harvest date for a municipality using FAO GAEZ data. Geography Controls includes mean temperature, mean precipitation, mean land suitability, the surface area, centroid latitude, centroid longitude, mean elevation, mean slope, log distance to Mexico City, and mean maize suitability for the municipality. Colonial Controls includes drought intensity in 1545 and log population density in 1570 using data from Sellers and Alix-Garcia (2018). For these colonial controls, values for municipalities with missing information are set to zero, and we control for an indicator variable equal to 1 if the municipality is not missing these colonial characteristics. Planting \& Harvest Month Fixed Effects are fixed effects for the optimal planting-month and harvest-month for maize for each municipality according to FAO GAEZ data. Festival-Week Fixed Effects are fixed effects for the calendar week of the municipality's saint day festival. ${ }^{*} p<0.10,{ }^{* *} p<0.05,{ }^{* * *} p<0.01$. 
Figure 5: Impact of Agriculturally-Coinciding Festivals on Development Outcomes:

Estimates for Economic Development Index Components

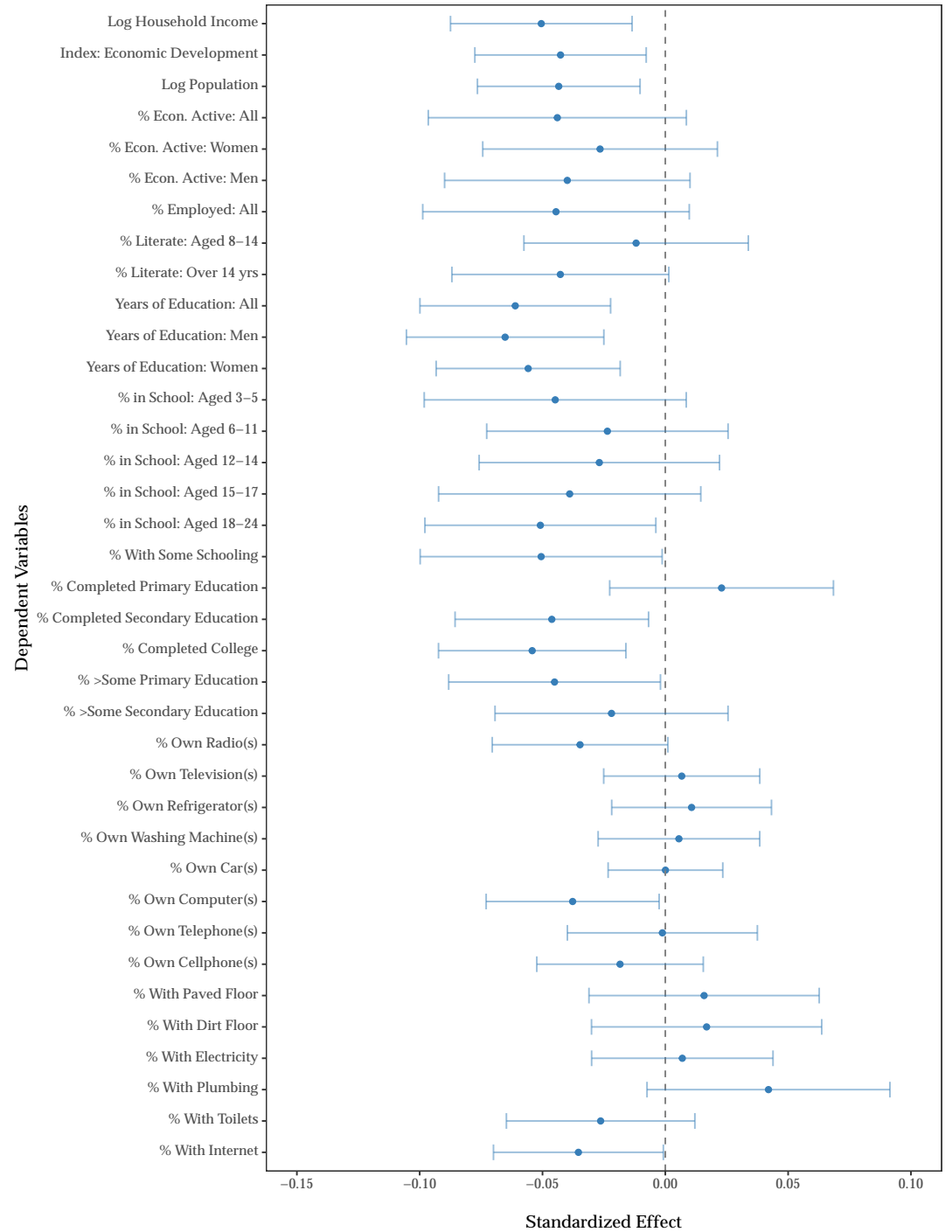

Notes: Data are from the 2010 Mexico Population Census for New Spain region of Mexico. The figure presents the estimated standardized coefficients and respective $95 \%$ confidence intervals from estimating equation (1) on the sub-components of the Index of Economic Development. The dependent variables are denoted on the y-axis. We first show the estimates for log household income, then for the Index of Economic Development, followed by estimates for each of the individual sub-components of the index (note, log household income is also one of the index components). See Data Appendix for more information. The independent variable is Festival Coincides with Maize Planting or Harvest: an indicator variable equal to 1 if the saint day festival in a municipality occurs either o to 30 days prior to the optimal maize planting date or o to 30 days after the optimal maize harvest date for a municipality using FAO GAEZ data. The regressions control for the full set of controls: State Fixed Effects, Geography Controls, Colonial Controls, Festival-Week Fixed Effects, and Planting- E Harvest-Month Fixed Effects. 
planting and festivals coinciding with harvest. Both planting-coinciding and harvest-coinciding festivals are associated with worse development outcomes. For both types of coinciding festivals, estimated effects are similar to the results from Table 2 in both magnitudes and statistical significance levels. ${ }^{42}$ Table $\mathrm{D}_{4}$ also shows p-values from testing the null hypothesis that the coefficients for the two types of coinciding festivals are the same. In all regressions, we fail to reject the null hypotheses that the effect of planting-coinciding and harvest-coinciding festivals are identical. Given this evidence that the effects of the two types of coinciding festivals are similar, in the remainder of this paper we estimate the impact of festivals coinciding with either planting or harvest (as in equation (I)).

\subsection{Impacts by Festival Timing Relative to Planting $\mathcal{E}$ Harvest}

A key hypothesis in Section 2 is that agriculturally-coinciding festivals have their negative effects by tightening liquidity constraints in periods when other highreturn but time-sensitive investments are available. If so, then the negative impacts of coinciding festivals should be largest in the months closest to harvest and planting, and closer to zero in months further away from these key periods. We test this prediction by estimating the impacts of festivals in other months relative to planting and harvest months. We estimate the following specification:

$$
y_{m}=\sum_{i=-3}^{3}\left(\beta_{i} \text { Festival: } i \text { Months from Planting }{ }_{m}+\gamma_{i} \text { Festival: } i \text { Months from Harvest }_{m}\right)+\alpha_{s(m)}+\mathbf{X}_{\mathbf{m}}^{\prime} \mathbf{B}+\epsilon_{m} \text { (3) }
$$

where our coefficients of interest are $\beta_{i}$ and $\gamma_{i}$, the effect of festivals occurring $i$ months from planting or harvest, respectively; and other variables are defined as before in equation ( 1 ).

Figure 6 presents these estimates of interest from estimating equation (3) on $\log$ household income. The largest effects occur when festivals coincide exactly with the period prior to the planting month or following the harvest month. The planting-month and harvest-month effects are both statistically significantly different from zero. Effects of festivals in other months adjacent to planting or harvest are much closer to zero, and none are statistically significant. These results are consistent with the hypothesis that festivals tighten liquidity constraints and crowd out key investments in the planting and harvest periods.

$4^{2}$ The exceptions are coefficients on planting-coincidence in Panel B. These coefficients remain large in magnitude but are relatively less precisely estimated. 
Figure 6: Impacts of Festival Coincidence with Other Months Relative to Planting and Harvest

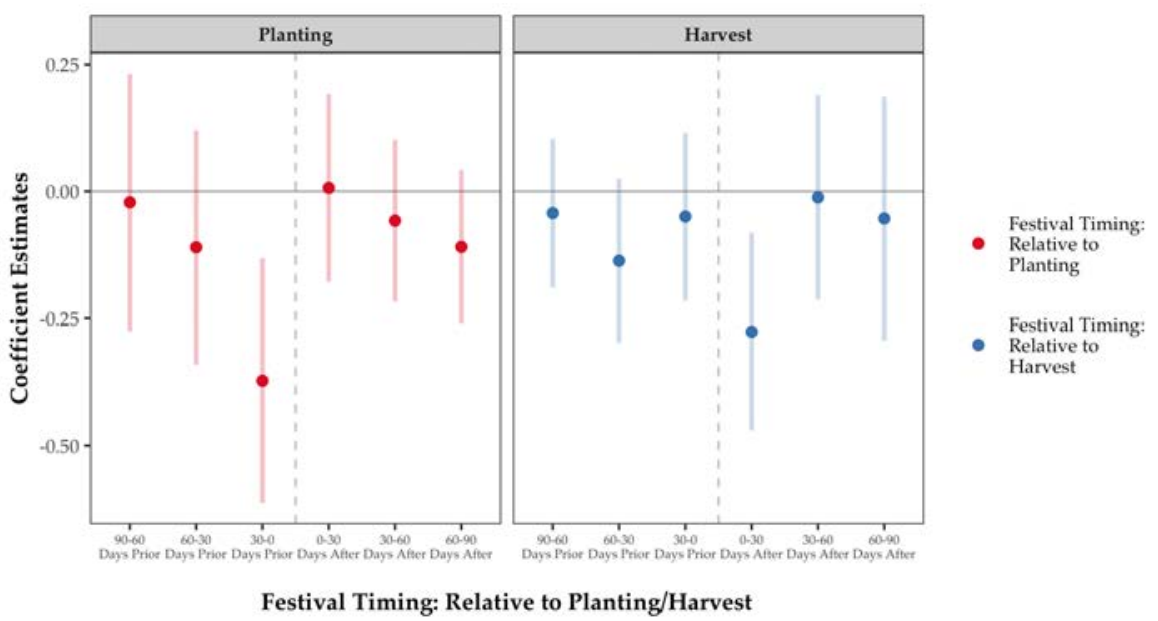

Notes: Data are from the 2010 Mexico Population Census for the New Spain region of Mexico. The figure presents the estimated $\beta_{i}$ and $\gamma_{i}$ coefficients and respective $95 \%$ confidence intervals from estimating equation (3). The outcome variable is Log Household Income. Festival Timing: Relative to Planting/Harvest is defined as the number of months before/after a municipality celebrates its festival relative to planting (top panel) and harvest (bottom panel) according to FAO GAEZ data. The regressions control for the full-set of controls: State Fixed Effects, Geography Controls, Colonial Controls, Festival-Week Fixed Effects, and Planting- E Harvest-Month Fixed Effects.

\subsection{Extensions E Robustness}

In this section, we carry out two robustness tests. First, we show that the results are robust to expanding the sample to include all municipalities in Mexico. Second, we conduct a randomization inference exercise assigning placebo festival dates to show that results are not driven by observations with high leverage.

\subsubsection{Expanding Sample to Include All Mexican Municipalities}

For reasons detailed in Section 4.2, our main results limit the sample to municipalities in the former New Spain region of Mexico. We now present our main results in the sample of all municipalities.

Table D5 presents coefficient estimates on the indicator for coinciding festivals (from estimating equation (I)) in regressions for log household income and for the index of economic development in the sample of all municipalities. The results are very similar to the results presented in Table 2: coinciding festivals are associated with lower household income and lower economic development 
index values. 43 Coefficients are negative in both panels, but slightly smaller in magnitude compared to Table 2. In regressions with the full set of controls, the coefficient on coinciding festivals remains statistically significant at conventional levels in Panel A, and at marginal statistical significance in Panel B. This reduction in coefficient magnitudes is consistent with festivals having less impact outside of New Spain for the reasons discussed in Section 4.2.

\subsubsection{Randomization Inference Exercise}

One potential concern with the main results in Table 2 is that they might be driven by outliers or high-leverage observations. To provide potentially more robust inference, we follow Young (2018) and conduct a randomization inference exercise, randomly assigning whether or not a municipality's festival coincides with planting or harvest months. We conduct 10,000 simulations where we randomly assign whether or not a festival coincides with planting or harvest for each municipality, and estimate equation (1). Figure $C_{2}$ presents the empirical cumulative distribution function of the estimated t-statistics for all the simulations, and denotes the estimated $t$-statistics from our sample with vertical lines. The estimated t-statistics in our sample for having a festival coincide with maize planting or harvest are much larger and more negative than the majority of placebo festival assignments, and the randomization inference p-value is 0.0004. The results from this randomization inference exercise suggest that our main results are unlikely to be driven by outliers or high-leverage observations.

\section{Mechanisms}

The results so far establish that agriculturally-coinciding festivals lead to worse economic development outcomes in the long run. We now explore mechanisms behind this effect. We argue that these impacts emerge because festivals during planting and harvest seasons crowd out high-return but time-sensitive agricultural investment opportunities. While there may be offsetting improvements in other outcomes (such as religiosity, social capital, and inequality) stemming from festivals, the net effect of planting- or harvest-season festivals is to compromise long-run growth.

${ }^{43}$ Appendix Table $\mathrm{D}_{3}$ presents the equivalent balance table as in Table $\mathrm{D}_{2}$ for all of Mexico and shows that coinciding festivals are not associated with differences in important geographic and historical variables in this broader sample of all Mexican municipalities. 


\subsection{Agricultural Productivity and Structural Transformation}

One important implication of the conceptual framework of Section 2 is that the agricultural sector in municipalities with coinciding festivals should be less productive, because coinciding festivals persistently crowd out high-return agricultural investments. We test whether municipalities with agriculturally-coinciding festivals have lower maize yields, using data from the Servicio de Información Agroalimentaria y Pesquera (SIAP). Column 1 of Table Di1 presents the estimate of the impact of coinciding festivals on maize yields. We find that municipalities with coinciding festivals have lower agricultural productivity: coinciding festivals lead to a 0.07 standard deviation decrease in maize yields.

We turn to examining the impact of festivals on municipality-level measures of structural transformation. Two-sector growth models of structural transformation would predict that lower agricultural productivity (due to having agriculturallycoinciding festivals) would lead to less structural transformation of the economy out of agriculture. (Herrendorf et al., 2014, Caselli, 2005).

To examine the impact of festivals on industrial structure, we use microdata from the 2010 Mexican Population Census to construct municipality-level measures of the share of workers in different industries (agriculture, manufacturing, and services). Columns 2 to 4 of Table Di1 present estimates of the impact of planting and harvest festivals on the structural transformation of the economy. Municipalities with coinciding festivals have higher shares of workers in agriculture and a lower share of workers in services. This is consistent with the prediction that the transition away from agriculture is hampered in areas with agriculturally-coinciding festivals (due to having lower agricultural productivity). By inhibiting the development of agriculture, coinciding festivals appear to slow the structural transformation of localities out of agriculture and into the modern economic sectors.

\subsection{Development Over Time}

Festivals coinciding with planting or harvest lead to worse development outcomes in the present day. We now ask when this effect emerged. We use a historical measure of economic development across municipalities of Mexico from Sellers and Alix-Garcia (2018): population density, which is often used as a proxy for economic development, particularly in historical studies in which data on other 
Table 3: Impact of Agriculturally-Coinciding Festivals on Agricultural Productivity and Structural Transformation

\begin{tabular}{|c|c|c|c|c|}
\hline & \multicolumn{4}{|c|}{ Dependent Variables: } \\
\hline & Maize Yield & $\%$ in Agriculture & $\%$ in Manufacturing & $\%$ in Services \\
\hline & $(1)$ & $(2)$ & (3) & $(4)$ \\
\hline Festival Coincides with Maize Planting or Harvest & $\begin{array}{r}-0.409^{*} \\
(0.219) \\
{[0.197]}\end{array}$ & $\begin{array}{c}0.028^{*} \\
(0.015) \\
{[0.014]}\end{array}$ & $\begin{array}{c}-0.004 \\
(0.008) \\
{[0.008]}\end{array}$ & $\begin{array}{c}-0.023^{*} \\
(0.013) \\
{[0.012]}\end{array}$ \\
\hline State Fixed Effects & Y & Y & $\mathrm{Y}$ & $\mathrm{Y}$ \\
\hline Geography Controls & $\mathrm{Y}$ & $\mathrm{Y}$ & $\mathrm{Y}$ & $\mathrm{Y}$ \\
\hline Colonial Controls & Y & Y & $\mathrm{Y}$ & $\mathrm{Y}$ \\
\hline Planting-Month Fixed Effects & Y & Y & Y & $\mathrm{Y}$ \\
\hline Harvest-Month Fixed Effects & Y & Y & $\mathrm{Y}$ & $\mathrm{Y}$ \\
\hline Festival-Week Fixed Effects & Y & Y & $\mathrm{Y}$ & $\mathrm{Y}$ \\
\hline Observations & 1,580 & 1,593 & 1,593 & 1,593 \\
\hline Adjusted R2 & 0.470 & 0.486 & 0.233 & 0.436 \\
\hline Mean Dep. Var. & 6.128 & 0.414 & 0.114 & 0.465 \\
\hline SD Dep. Var. & 4.140 & 0.237 & 0.095 & 0.198 \\
\hline
\end{tabular}

Notes: Maize yield data are from the Servicio de Información Agroalimentaria y Pesquera (SIAP) for 2010, and other outcomes from the 2010 Population Census. Observations are municipalities in the New Spain region of Mexico. Robust standard errors are presented in parentheses and Conley (1999) standard errors calculated using a $100 \mathrm{~km}$ cut-off window are presented in brackets. Maize Yield is the mean maize revenue yield in thousand of pesos per hectare for a municipality in 2010. \% in Agriculture is the share of workers in a municipality who work in agriculture. \% in Manufacturing is the share of workers in a municipality who work in manufacturing. \% in Services is the share of workers in a municipality who work in the service industry. Festival Coincides with Maize Planting or Harvest is an indicator variable equal to 1 if the saint day festival in a municipality occurs either 0 to 30 days prior to the optimal maize planting date or 0 to 30 days after the optimal maize harvest date for a municipality using FAO GAEZ data. Geography Controls includes mean temperature, mean precipitation, mean land suitability, the surface area, centroid latitude, centroid longitude, mean elevation, mean slope, log distance to Mexico City, and mean maize suitability for the municipality. Colonial Controls includes drought intensity in 1545 and $\log$ population density in 1570 using data from Sellers and Alix-Grcin (2018). For these colonial controls, values for municipalities and log populities with ming these colonial characteristics. Planting $\mathcal{E}$ Harvest Month Fixed Effects includes fixed effects for the optimal planting-month and harvest-month for maize for each municipality according to FAO GAEZ data. Festival-Week Fixed Effects are fixed effects for the calendar week of the municipality's saint day festival. ${ }^{*} p<0.10,{ }^{* *} p<0.05,{ }^{* * *} p<0.01$.

development outcomes are not available (e.g., Acemoglu et al., 2002). We examine impacts on population density in 1570, 1650, 1900, and 2010, and plot the coefficients representing the effect of coinciding festivals in Figure 7.44

We find that having agriculturally-coinciding festivals does not affect population density in 1570 or 1650 , but does lead to lower population density in 1900 and in 2010. The negative point estimate is larger in magnitude in 2010 than in 1900, but confidence intervals are large and we cannot reject that the effects on population density are similar in 1900 and 2010. The results indicate that the impacts of coinciding festivals on development emerged sometime after 1650, and were already perceptible in the data by the end of the 19th century.

The pattern we see in Figure 7 - the fact that negative economic impacts had

${ }^{44}$ To deal with changing municipality borders over time, we use the concordance of Sellers and Alix-Garcia (2018) to create consistent historical municipal population data across 1545, 1650 and 1900. (There were very few major changes post-1900, and they were for areas outside of New Spain.) 
Figure 7: Impact of Agriculturally-Coinciding Festivals on Population

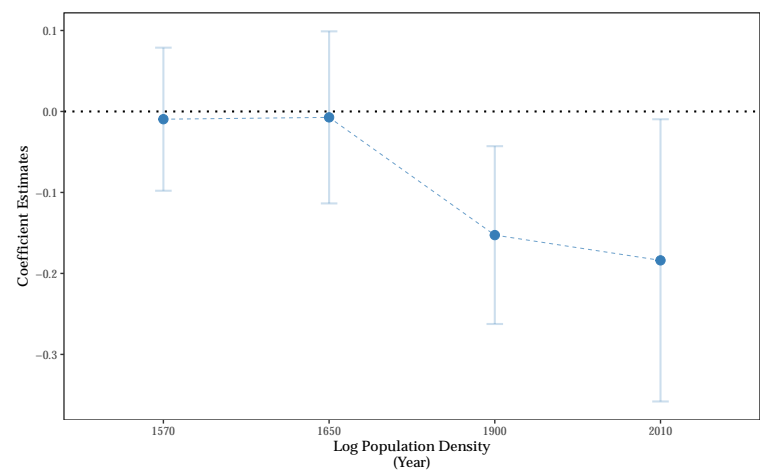

\begin{abstract}
Notes: Data on log population density for 1570, 1650, and 1900 is from Sellers and Alix-Garcia (2018). Data on population density for 2010 is from the 2010 Mexico Population Census. The figure presents the estimated coefficients and respective $95 \%$ confidence intervals from estimating equation (1) for various measures of log population density across time. Observations throughout are municipalities in the New Spain region of Mexico that have historical population density (1,395 municipalities in each year). The independent variable is Festival Coincides with Maize Planting or Harvest, an indicator variable equal to 1 if the saint day festival in a municipality occurs either o to 30 days prior to optimal maize planting month or o to 30 days after the optimal maize harvest month for that municipality using FAO GAEZ data. The regressions control for the full set of controls: State Fixed Effects, Geography Controls, Colonial Controls, Festival-Week Fixed Effects, and Planting- $\mathcal{E}$ Harvest-Month Fixed Effects.
\end{abstract}

already emerged by 1900 - provides additional insight into our overall findings on two dimensions. First, it suggests that at least some of the economic mechanisms through which coinciding festivals reduce agricultural productivity (outlined in Section 2 above) were already operative prior to the 2oth century. Second, the pattern suggests that the broader modernization of the economy, and any changes in how festivals have been celebrated in the zoth century, have not led to economic convergence between places with and without coinciding festivals.

\title{
8. Religiosity, Social Capital, and Other Outcomes
}

We now explore how festivals coinciding with planting and harvest affect religiosity, social capital, income inequality, and migration. These are outcomes of independent interest. In addition, impacts on religiosity could help explain why coinciding festivals persist, notwithstanding their negative impacts on economic development.

To examine the impact of coinciding festivals on religiosity and social capital, we use survey data from the Americasbarometer from 2008 to 2018. For reli- 
giosity, we construct an index from three questions: the importance of religion to an individual, church attendance, and religious group attendance. For the importance of religion question, the survey asks how important religion is to a respondent. The church attendance question asks how frequently an individual goes to church. For religious group attendance, the survey asks respondents how frequently an individual participates in religious group meetings. Our religiosity index is the first principal component of these three religion questions. ${ }^{45}$ To measure social capital, we construct an index from questions on the frequency with which a respondent participates in four different types of group meetings: community improvement groups, parental associations, municipal meetings, and political associations. ${ }^{6}$ We define our index as the first principal component of these four questions. Further detail is provided in Appendix A.

Table 4 presents regression estimates of the impact of coinciding festivals on the religiosity and social capital indices, while Figure $C_{3}$ presents estimates of the impacts of coinciding festivals on each of the individual components of the religiosity and social capital indexes. We find that municipalities with coinciding festivals have higher levels of religiosity and social capital (columns 1 and 2 of Table 4, respectively). Additionally, we find that, broadly speaking, coinciding festivals have positive effects on each of the religiosity index and social capital index components (see Figure $C_{3}$ ). Across all the components of the indices, the only one for which coinciding festivals do not have a positive effect is political group participation.

As discussed in Section 2, there are two reasons why coinciding festivals could lead to with higher religiosity. Agriculturally-coinciding festivals, as higher-cost signals of religious adherence, could have a direct, positive effect on religiosity. In addition, there could be an indirect effect, as lower economic development resulting from agriculturally-coinciding festivals slows the secularization process, increasing religiosity. The resulting increase in religiosity could help explain why agriculturally-coinciding festivals persist: more religious communities may have

\footnotetext{
${ }^{45}$ Note that these are the full set of religion questions in the LAPOP surveys; however, they were not asked in every wave consistently. For waves without the full set of questions, we construct our index using the subset of questions that were asked. (All survey waves have at least two out of the three questions.) However, we show in Figure $C_{3}$ that the results hold for each individual component.

${ }^{46}$ These are the full set of groups that appear consistently in all waves we examine. In Figure $C_{3}$, we show the results for each individual component.
} 
Table 4: Impact of Agriculturally-Coinciding Festivals on Religiosity, Social Capital, and Inequality

\begin{tabular}{|c|c|c|c|}
\hline & \multicolumn{3}{|c|}{ Dependent Variables: } \\
\hline & Religiosity Index & Group Membership Index & IQR of Earned Incomes \\
\hline & $(1)$ & $(2)$ & (3) \\
\hline Festival Coincides with Maize Planting or Harvest & $\begin{array}{l}0.315^{*} \\
(0.162) \\
{[0.155]}\end{array}$ & $\begin{array}{c}0.240^{*} \\
(0.135) \\
{[0.125]}\end{array}$ & $\begin{array}{c}-0.289^{* * *} \\
(0.103) \\
{[0.111]}\end{array}$ \\
\hline State Fixed Effects & Y & Y & $\mathrm{Y}$ \\
\hline Geography Controls & $\mathrm{Y}$ & $\mathrm{Y}$ & $\mathrm{Y}$ \\
\hline Colonial Controls & $\mathrm{Y}$ & $\mathrm{Y}$ & $\mathrm{Y}$ \\
\hline Planting-Month Fixed Effects & $\mathrm{Y}$ & $\mathrm{Y}$ & $\mathrm{Y}$ \\
\hline Harvest-Month Fixed Effects & $\mathrm{Y}$ & Y & $\mathrm{Y}$ \\
\hline Festival-Week Fixed Effects & Y & Y & $\mathrm{Y}$ \\
\hline Observations & 4,796 & 4,818 & 1,593 \\
\hline Clusters & 131 & 131 & 1593 \\
\hline Adjusted R2 & 0.129 & 0.050 & 0.555 \\
\hline Mean Dep. Var. & -0.187 & 0.063 & 2.168 \\
\hline SD Dep. Var. & 1.266 & 1.306 & 1.833 \\
\hline
\end{tabular}

Notes: Data are from the Americas Barometer (LAPOP) data (religiosity and social capital) and from the 2010 Mexico Population Censuses from IPUMS (inequality). Observations are individuals in municipalities in the New Spain region of Mexico. Standard errors clustered at the municipality level are presented in parentheses and Conley (1999) standard errors calculated using a $100 \mathrm{~km}$ cut-off window are presented in brackets. Religiosity Index is the first principal component of the following variables: Importance of Religion, Church Attendance, and Religious Group Attendance. Importance of Religion is a 1-4 categorical variable that measures how important religion is to a respondent, ranging from $1=$ "Not Important at All" to $4=$ "Very Important". Church Attendance is a 1-5 categorical variable that measures how frequently an individual goes to church, ranging from $1=$ "Never" to $5=$ "More than Once a Week". Religious Group Attendance is a 1-4 categorical variable that measures how frequently an individual participates in religious group meetings, ranging from $1=$ "Never" to $4=$ "Once a Week". Group Membership Index is the first principal component for the frequency with which a respondent participates in the following group meetings: community improvement, parental associations, municipal meetings, or political associations. IQR of Earned Incomes measures the inter-quartile range of individuals total income from their labor (from wages, a business, or a farm) in the previous month for individuals residing in a given municipality. Festival Coincides with Maize Planting or Harvest is an indicator variable equal to 1 if the saint day festival in a municipality occurs either 0 to 30 days prior to the optimal maize planting date or 0 to 30 days after the optimal maize harvest date for a municipality using FAO GAEZ data. All regressions controls for respondent age, age squared, gender, and include survey-wave fixed effects. Geography Controls includes mean temperature, mean precipitation, mean land suitability, the surface area, centroid latitude, centroid longitude, mean elevation, mean slope, log distance to Mexico City, and mean maize suitability for the municipality. Colonial Controls includes drought intensity in 1545 and log population density in 1570 using data from Sellers and Alix-Carcia (2018). For these Colonial Conto colonich municipality is not missing these colonial characteristics. Planting \& Harvest Month Fixed Effects includes fixed effects for the optimal planting-month and harvest-month for maize for each municipality according to FAO GAEZ data. Festival-Week Fixed Effects are fixed effects for the calendar week of the municipality's saint day festival. ${ }^{*} p<0.10,{ }^{* *} p<0.05,{ }^{* * *} p<0.01$.

stronger preferences to maintain their religious traditions, even in the face of negative economic consequences.

We also investigate the impact of agriculturally-coinciding festivals on income inequality. There could be an impact of coinciding festivals on inequality, for two reasons. First, because coinciding festivals lead to higher religiosity and social capital, these festivals might also lead to more redistribution and, therefore, lower inequality. 47 Second, as economic growth typically coincides with increases in income inequality, we may also expect that agriculturally-coinciding festivals may

47Resource transfers during the festival itself (e.g., feasting provided by mayordomos to the population at large) may be one mechanism through which redistribution occurs. More importantly, places with coinciding festivals (due to their higher social capital) may also engage in more redistribution via means such as local public good provision (e.g., schools, infrastructure) or via provision of informal insurance, credit, or transfers within the community. 
reduce inequality.

We use microdata from the 2010 Mexican Population Census to construct municipality-level measures of income inequality. We construct measures of the inter-quartile range (IQR) of earned income for individuals in a municipality, where earned income is defined as an individual's total income from their labor (from wages, a business, or a farm) in the previous month.

Column 3 of Table 4 presents regression estimates of the impact of coinciding festivals on income inequality. We find that municipalities with coinciding festivals have lower levels of income inequality. This finding that agriculturallycoinciding festivals lead to both lower development and less inequality suggest an equity-efficiency trade-off in this context (Kuznets, 1955).

Finally, we consider the impacts of coinciding festivals on migration. Lower economic development due to coinciding festivals could either raise or lower migration, depending on the interplay between migration fixed costs, migration returns, and liquidity constraints (Bazzi, 2017). Higher social capital due to coinciding festivals may facilitate migrant opportunities to engage in long-distance trade (Grief, 1993). At the same time, higher social capital may enhance the informal insurance provided by the village, discouraging migration (Banerjee and Newman, 1993). Migration could also be an intermediating mechanism for the long-run effects of coinciding festivals, for example if migration is selective (e.g., on the basis of ability), changing the long-run composition of the population. $4^{8}$

We have little ability to examine migration in historical periods, and how it may have shaped the cumulative effects of coinciding festivals. We therefore simply examine the impact of coinciding festivals on four migration outcomes in the 2010 Mexican Census: shares of population who were born in a different state, resided in a different municipality five years before, resided in a different state five years before, or resided in a different country five years before. Table Di1 presents the results. We find that municipalities with coinciding festivals have higher shares of the population who report having been in a different country five years before. This likely represents higher temporary labor migration to the U.S. This finding is consistent with prior work finding that relative worsening of economic conditions in origin areas leads to higher outmigration (e.g., Munshi,

\footnotetext{
${ }^{48}$ The selectivity of migration can be complex, as prior work on Mexico has emphasized (Chiquiar and Hanson, 2005, McKenzie and Rapoport, 2010).
} 
2003, Yang, 2006, Yang and Choi, 2007, Hanson and McIntosh, 2012, Groger and Zylberberg, 2016, Abarcar, 2017, Mahajan and Yang (2020), Clemens, 2021).49

\section{Conclusion}

Our findings contribute to the literature on the economics of religion, by shedding light on the economic consequences of variation in an important and widespread religious practice, festival celebrations. We also bring a new insight to the development economics literature: festival celebrations can reduce the ability to take advantage of time-sensitive economic opportunities in agriculture, and over the long run lead to persistently lower agricultural productivity and less transformation of the economy to the modern sectors.

Because our study municipalities (nearly) all celebrate Catholic saint day festivals, we cannot say whether festivals in general have positive or negative consequences for economic development overall. It is possible that non-coinciding festivals could be good for economic development, and our finding that coinciding festivals have negative consequences is relative to that positive baseline effect. Moreover, while we find that localities with coinciding festivals are less developed economically, it is unclear whether households in these localities have lower utility overall, because coinciding festivals also lead to increases in religiosity and reductions in economic inequality. Higher utility resulting from greater religiosity and lower inequality may offset declines in utility due to lower economic development, making the net effect of coinciding festivals on utility ambiguous.

With these caveats in mind, what implications might our results have for public policy? If a community is seeking to reduce the economic impacts of coinciding festivals, a general principle would be to reduce the extent to which festivals' financial and time commitments crowd out contemporaneous economic investments. Public officials can set deadlines for key household investments (e.g., school fee payments) to avoid conflicts with festival periods, or create flexibility to allow such payments at different times. Efforts to facilitate early commitment of agricultural planting investments, such as nudges to purchase fertilizer at harvest time (Duflo et al., 2011), could help reduce crowd-out. Communities could also

\footnotetext{
49 There is a more tentative indication that coinciding festivals also lead to a reduction in internal migration within Mexico (a reduction in share of population that has been in a different state five years before), but this result is not robust to examining other measures of internal migration.
} 
consider putting limits on festival expenditures, as the colonial government did in the 1790s (Tanck de Estrada and Marichal, 2010), and on the time and effort expected from households. While a bit inconceivable in practice, policy levers in principle also include shifting festival celebration dates so as not to coincide with key periods when time-sensitive investment opportunities exist (like agricultural planting and harvest seasons).

An intriguing additional policy implication of our results is that provision of liquidity (e.g., via credit or savings schemes) during festival times could have benefits by reducing crowd-out of other time-sensitive investments. Provision of such liquidity motivates a specific institution observed in many Catholic countries: the practice by employers of withholding a portion of annual compensation until December, when a "thirteenth salary" (often referred to as aguinaldo) is paid (Globalization Partners, 2019)..$^{\circ}$ Analogously, "Christmas clubs" - no-interest commitment savings accounts to facilitate household savings for Christmas expenditures - were long popular in the United States (Thaler and Shefrin, 1981). By facilitating acquisition of a lump sum of resources, Christmas clubs and aguinaldo practices provide liquidity for Christmas celebration expenses, and may reduce crowd-out of other economic investments. Policy-makers - with the cooperation of private firms - could consider implementing aguinaldo-style practices to help reduce the crowd-out of economic investments whose timings coincide with festival periods. These policies could be national in scope like present-day aguinaldo practices, but could also be designed at the sub-national level for local celebrations like the saint day festivals we study.

As is the case for all empirical research, future studies should seek to determine the external validity of these findings. The rest of the Catholic world provides natural new contexts in which to conduct follow-on investigations, potentially using analogous empirical strategies exploiting the coincidence of festival dates with agricultural seasons. Researchers should also explore other contexts where there may be exogenous variation in whether localities celebrate festivals at all, to shed light on the extensive margin impacts of festivals. In addition, it would be valuable to conduct micro-level studies to provide detailed evidence on the types

\footnotetext{
$5^{5}$ Deferred wage payment schemes like aguinaldo practices also exist in non-Christian countries (e.g., China, where the timing provides liquidity for the Lunar New Year celebration). Brune et al. (2021) provide recent evidence that workers show nontrivial demand for such deferred wage payment schemes, because they facilitate acquisition of lump sums for investment when there are savings constraints (such as self-control problems).
} 
of investments that are crowded out by coinciding festivals, and what conditions attenuate or exacerbate such crowding-out. We view these as promising directions for future research.

\section{References}

Abarcar, Paolo, "The Return Motivations of Legal Permanent Migrants: Evidence from Exchange Rate Shocks and Immigrants in Australia," Journal of Economic Behavior and Organization, 2017, 144, 62-77.

Acemoglu, Daron, Simon Johnson, and James A. Robinson, "Reversal of Fortune: Geography and Institutions in the Making of the Modern World Income Distribution," Quarterly Journal of Economics, 2002, 117 (4), 1231-1294.

Aiyar, Shekhar, Carl-Johan Dalgaard, and Omer Moav, "Technological Proress and Regress in Pre-Industrial Times," Journal of Economic Growth, 2008, 13, 125-144.

Alesina, Alberto, Sebastian Hohmann, Stelios Michalopoulos, and Elias Papaioannou, "Religion and Educational Mobility in Africa," 2020. NBER Working Paper 28270.

Ashraf, Qamrul and Oded Galor, "Dynamics and Stagnation in the Malthusian Epoch," American Economic Review, 2011, 101 (5), 2003-2040.

Atkinson, Matthew D. and Anthony Fowler, "Social Capital and Voter Turnout: Evidence from Saint's Day Fiestas in Mexico," British Journal of Political Science, 2014, 44 (1), 41-59.

Augenblick, Ned, Kelsey Jack, Supreet Kaur, Felix Masiye, and Nicholas Swanson, "Budget Neglect in Consumption Smoothing: A Field Experiment on Seasonal Hunger," 2021. Working Paper.

Banerjee, Abhijit and Andrew Newman, "Occupational Choice and the Process of Development," Journal of Political Economy, 1993, 101 (2), 274-298.

Banerjee, Abhijit V. and Esther Duflo, Poor Economics: A Radical Rethinking of the Way to Fight Global Poverty, New York, United States: Public Affairs, 2011.

Bazzi, Samuel, "Wealth Heterogeneity and the Income Elasticity of Migration," American Economic Journal: Applied Economics, 2017, 9 (2), 219-255.

Beam, Emily A. and Slesh A. Shrestha, "Superstition, Fertility, and Interethnic Spillovers: Evidence from Peninsular Malaysia," Economic Development and Cultural Change, 2020, 69 (1), 453-483.

Becker, Sascha O., Markus Nagler, and Ludger Woessmann, "Education and Religious Participation: City-level Evidence from Germany's Secularization Period 1890-1930," Journal of Economic Growth, 2017, 22, 273-311.

Beezley, William and Michael Meyer, The Oxford History of Mexico, Oxford, United Kingdom: Oxford University Press, 2010.

Bentzen, Jeanet S., "Acts of God? Religiosity and Natural Disasters Across Subnational World Districts," The Economic Journal, 2019, 129 (622), 2295-2321.

Brandes, Stanley, "Cargos versus Cost Sharing in Mesoamerican Fiestas, with Special Reference to Tzintzuntzan," Journal of Anthropological Research, 1981, 37 (3), 209-225.

Brune, Lasse, Eric Chyn, and Jason Kerwin, "Pay Me Later: Savings Constraints and the Demand for Deferred Payments," American Economic Review, 2021, 111 (7), 2179-2212. 
Bryan, Gharad, James J Choi, and Dean Karlan, "Randomizing Religion: the Impact of Protestant Evangelism on Economic Outcomes," Quarterly Journal of Economics, 2021, 136 (1), 293-380.

Burke, Marshall, Lauren Falcao Bergquist, and Edward Miguel, "Sell Low and Buy High: Arbitrage and Local Price Effects in Kenyan Markets," The Quarterly Journal of Economics, 2019, 134 (2), 785-842.

Bustos, Paula, Gabriel Garber, and Jacopo Ponticelli, "Capital Accumulation and Structural Transformation," The Quarterly Journal of Economics, 2020, 135 (2), 1037-1094.

Campante, Filipe and David Yanagizawa-Drott, "Does Religion Affect Economic Growth and Happiness? Evidence from Ramadan," The Quarterly Journal of Economics, 2015, 130 (2), 615-658.

Caselli, Francesco, "Accounting for Cross-Country Income Differences," Handbook of Economic Growth, 2005, I (A), 679-741.

- and Wilbur John Coleman, "The U.S. Structural Transformation and Regional Convergence: A Reinterpretation," Journal of Political Economy, 2001, 109 (3), 584-616.

Chance, John K. and William B. Taylor, "Cofradías and Cargos: An Historical Perspective on the Mesoamerican Civil-Religious Hierarchy," American Ethnologist, 1985, 12 (1), 126.

Chiquiar, Daniel and Gordon Hanson, "International Migration, Self-Selection, and the Distribution of Wages: Evidence from Mexico and the United States," Journal of Political Economy, 2005, 113 (2), 239-281.

Clemens, Michael, "Violence, Development, and Migration Waves: Evidence from Central American Child Migrant Apprehensions," Journal of Urban Economics, 2021.

Clingingsmith, David, Asim Ijaz Khwaja, and Michael Kremer, "Estimating the Impact of The Hajj: Religion and Tolerance in Islam's Global Gathering," Quarterly Journal of Economics, 2009, 124 (3), 1133-1170.

Conley, Timothy, "GMM Estimation with Cross Sectional Dependence," Journal of Econometrics, 1999, 92, 1-45.

Cook, Edward and Paul Krusic, The North American Drought Atlas, New York, United States: Lamont-Doherty Earth Observatory and National Science Foundation, 2004.

Deaton, Angus and Arthur A. Stone, "Two Happiness Puzzles," AmericanEconomic Review Papers \& Proceedings, 2003, 103, 91-97.

Dewalt, Billie, "Changes in the Cargo Systems of MesoAmerica," Anthropological Quarterly, 1975, 48 (2), 87-105.

_ , "Reviewed Work: The Fiesta System and Economic Change," American Ethnologist, 1979, 6 (1), 201-204.

Dow, James, Santos y Supervivencias: Funciones de la Religión en una Comunidad, Mexico City, Mexico: Instituto Nacional Indigenista y Secretaría de Educación Pública, 1974.

Duflo, Esther, Michael Kremer, and Jonathan Robinson, "Nudging Farmers to Use Fertilizer: Theory and Experimental Evidence from Kenya," American Economic Review, 2011, 101 (6), 2350-2390.

Durkheim, Émile, The Elementary Forms of the Religious Life: A Study in Religious Sociology, New York, United States: Macmillan, 1912.

Fischer, Gunther, Freddy Nachtergaele, Sylvia Prieler, Edmar Teixeira, Géza Tóth, 
Harrij van Velthuizen, Luc Verelst, and David Wiberg, "Global Agro-ecological Zones: Model Documentation," 2012. GAEZ ver 3.o Model Documentation, Food and Agriculture Organization of the United Nations (FAO).

Foster, Andrew and Mark Rosenzweig, "Agricultural Productivity Growth, Rural Economic Diversity, and Economic Reforms: India, 1970-2000," Economic Development and Cultural Change, 2004, 52 (3), 509-542.

Galor, Oded and David Weil, "Population, Technology, and Growth: From Malthusian Stagnation to the Demographic Transition and Beyond," American Economic Review, 2000, 90 (4), 806-828.

- and Omer Ozak, "The Agricultural Origins of Time Preference," American Economic Review, 2016, 106 (10), 3064-3103.

Gerhard, Peter, A Guide to the Historical Geography of New Spain, Revised Edition, Norman, United States: University of Oklahoma Press, 1993.

Gibson, Charles, The Aztecs Under Spanish Rule: A History of the Indians of the Valley of Mexico, 1519-1810, Stanford, United States: Stanford University Press, 1964.

Globalization Partners, "13th Month Pay: An Employer's Guide to Monetary Benefits," 2019. Globalization Partners Expansion Guide.

Gollin, Douglas, Casper Worm Hansen, and Asger Wingender, "Two Blades of Grass: The Impact of the Green Revolution," 2021.

_ , Stephen Parente, and Richard Rogerson, "The Role of Agriculture in Development," American Economic Review: Papers and Proceedings, 2002, 92 (2), 160-164.

_ , _ , and _ , "The Food Problem and the Evolution of International Income Levels," Journal of Monetary Economics, 2007, 54 (4), 1230-1255.

Greenberg, James, Santiago's Sword: Chatino Peasant Religion and Economics, Berkeley, United States: University of California Press, 1981.

Grief, Avner, "Contract Enforceability and Economic Institutions in Early Trade: The Maghribi Traders' Coalition," American Economic Review, 1993, 83 (3), 525-548.

Groger, André and Yanos Zylberberg, "Internal Labor Migration as a Shock Coping Strategy: Evidence from a Typhoon," American Economic Journal: Applied Economics, 2016.

Guiso, Luigi, Paola Sapienza, and Luigi Zingales, "People's Opium? Religion and Economic Attitudes," Journal of Monetary Economics, 2003, 50, 225-282.

_ , _ , and _ , "Does Culture Affect Economic Outcomes?," Journal of Economic Perspectives, 2006, 20, 23-48.

Hanson, Gordon and Craig McIntosh, "Birth Rates and Border Crossings: Latin American Migration to the US, Canada, Spain and the UK," Economic Journal, 2012, 122, 707-26.

Harris, Marvin, Patterns of Race in the Americas, New York, United States: Walker and Company, 1964 .

Herrendorf, Berthold, Richard Rogerson, and Akos Valentinyi., "Growth and Structural Transformation," in Philippe Aghion and Steven Durlauf, eds., Handbook of Economic Growth, 1 ed., Vol. 2 2014, chapter 6, pp. 855-941.

Hijmans, R.J., S.E. Cameron, J.L. Parra, P.G. Jones, and A. Jarvis, "Very High Resolution Interpolated Climate Surfaces for Global Land Areas," International Journal of Climatol- 
ogy, 2005, 25, 1965-1978.

Hungerman, Daniel, "The Effect of Education on Religion: Evidence from Compulsory Schooling Laws," Journal of Economic Behavior E Organization, 2014, 104 (C), 52-63.

Iannaccone, Laurence, "Sacrifice and Stigma: Reducing Free-Riding in Cults, Communes, and Other Collectives," Journal of Political Economy, 1992, 100 (2), 271-291.

INAFED, Instituto Nacional para el Federalismo y el Desarrollo Municipal, "Enciclopedia de los Municipios y Delegaciones de México," 1988.

Iyer, Sriya, "The New Economics of Religion," Journal of Economic Literature, 2016, 54 (2), 395-441.

Johnson, D. Gale, "Population, Food, and Knowledge," American Economic Review, 2000, $90(1), 1-14$.

Johnston, Bruce F. and John W. Mellor, "The Role of Agriculture in Economic Development," American Economic Review, 1961, 51 (4), 566-593.

Karlan, Dean and Jonathan Morduch, "Access to Finance," Handbook of Development Economics, 2010, 5 (1), 4703-4784.

Kremer, Michael, "Population Growth and Technological Change: One Million B.C. to 1990," Quarterly Journal of Economics, 1993, 108 (3), 681-716.

Kuroda, Etsuko, "Data on the Civil-Religious Organization of the Highland Mixe Society of Oaxaca, Mexico," Senri Ethnological Studies, 1979, 2 (1), 197-246.

Kuznets, Simon, "Economic Growth and Income Inequality," American Economic Review, 1955, 45 (1), 1-28.

Lastra, Yolanda, Dina Sherzer, and Joel Sherzer, Adoring the Saints: Fiestas in Central Mexico, Austin, United States: University of Texas Press, 2009.

Levy, Gilat and Ronny Razin, "Rituals or Good Works: Social Signaling in Religious Organizations," Journal of the European Economic Association, 2014, 12 (5), 1317-1360.

Lim, Chaeyoon and Robert D. Putnam, "Religion, Social Networks, and Life Satisfaction," American Sociological Review, 2010, 75, 905-933.

Lipford, Jody W. and Robert D. Tollison, "Religious Participation and Income," Journal of Economic Behavior E Organization, 2003, 51 (2), 249-26o.

MacCulloch, Diarmaid, A History of Christianity: The First Three Thousand Years, Allen Lane, 2009.

Mahajan, Parag and Dean Yang, "Taken by Storm: Hurricanes, Migrant Networks, and US Immigration," American Economic Journal: Applied Economics, April 2020, 12 (2), 25077 .

Malthus, Thomas, An Essay on the Principle of Population, Reprint, Oxford University Press, 1999, 1798.

McAlister, Lyle, Spain and Portugal in the New World, 1492-1700, University of Minnesota Press, 1984.

McCleary, Rachel M. and Robert J. Barro, "Religion and Economy," Journal of Economic Perspectives, 2006, 20 (2), 760-781.

_ and _ , The Wealth of Religions: The Political Economy of Believing and Belonging, Princeton, United States: Princeton University Press, 2019.

McKenzie, David and Hillel Rapoport, "Self-Selection Patterns in Mexico-U.S. Migration: 
The Role of Migrant Networks," The Review of Economics and Statistics, 2010, 92 (4), 811-821.

Monaghan, John, "Reciprocity, Redistribution, and the Transaction of Value in the Mesoamerican Fiesta," American Ethnologist, 1990, 17 (4), 758-774.

_ , "Fiesta Finance in Mesoamerica and the Origins of a Gift Exchange System," The Journal of the Royal Anthropological Institute, 1996, 2 (3), 499-516.

Munshi, Kaivan, "Networks in the Modern Economy: Mexican Migrants in the U.S. Labor Market," Quarterly Journal of Economics, 2003, 118 (2).

Nunn, Nathan, "Religious Conversion in Colonial Africa," American Economic Association Papers and Proceedings, 2010, 100, 147-152.

_ , "Culture and the Historical Process," Economic History of Developing Regions, 2012, 27, 108-126.

- and Nancy Qian, “The Potato's Contribution to Population and Urbanization: Evidence From A Historical Experiment," The Quarterly Journal of Economics, 2011, 126 (2), $593-650$.

Nutini, Hugo G., San Bernardino Contla: Marriage and Family Structure in a Tlaxcalan Municipio 1968.

_ , "Syncretism and Acculturation: The Historical Development of the Cult of the Patron Saint in Tlaxcala, Mexico (1519-1670)," Ethnology, 1976, 15 (3), 301-321.

Paldam, Martin and Erich Gundlach, "The Religious Transition: A Long-run Perspective," Public Choice, 2013, 156 (1), 105-123.

Putnam, Robert D., Bowling Alone: The Collapse and Revival of American Community, New York, United States: Simon \& Schuster, 2000.

Ragon, Pierre, "Los Santos Patronos De Las Ciudades Del Mexico Central (Siglos XVI y XVII)," Historia Mexicana, 2002, 52 (2), 361-389.

Ramankutty, Navin, Jonathan A. Foley, John Norman, and Kevin McSweeney, "The Global Distribution of Cultivable Lands: Current Patterns and Sensitivity to Possible Climate Change," Global Ecology and Biogeography, 2002, 11, 377-392.

Rao, Vijayendra, "Celebrations as Social Investments: Festival Expenditures, Unit Price Variation, and Social Status in Rural India," Journal of Development Studies, 2001, 38 (1), 71-97.

Restuccia, Diego, Dennis Tao Yang, and Xiaodong Zhu, "Agriculture and Aggregate Productivity: A Quantitative Cross-country Analysis," Journal of Monetary Economics, 2008, 55 (2), 234-250.

Ricketts, Taylor H., Eric Dinerstein, David M. Olson, Colby J. Loucks, William Eichbaum, Dominick A. DellaSala, Kevin Kavanagh, Prashant Hedao, Patrick Hurley, Karen Carney, Robin Abell, and Steven Walters, Terrestrial Ecoregions of North America, Washington DC, United States: Island Press, 1999.

Rosales Martínez, G., H. Navarro Garza, D. Flores Sánchez, J.F. Núñez Espinoza, M.A. Jiménez Velázquez, and L.Y. Peña Avelino, "Solidaridad en la Modernidad de las Fiestas Patronales del Distrito de Tlaxiaco," Textual, 2020, 75 (1), 217-241.

Schofield, Heather, "Ramadan Fasting and Agricultural Output," 2020. Working Paper.

Schultz, Theodore W., Economic Organization of Agriculture, New York, United States: McGraw-Hill Book Company, 1953.

Sellers, Emily A. and Jennifer Alix-Garcia, "Labor Scarcity, Land Tenure, and Historical 
Legacy: Evidence from Mexico," Journal of Development Economics, 2018, 135, 504-516.

Smith, Waldemar, The Fiesta System and Economic Change, New York, United States: Columbia University Press, 1977.

Stanley, Brian, The Bible and the Flag: Protestant Mission and British Imperialism in the 19th and 20th Centuries, Apollos, 1990.

Stifel, David, Marcel Faschamps, and Bart Minten, "Taboos, Agriculture and Poverty," Journal of Development Studies, 2011, 47 (10), 1455-1481.

Suzuki, Mizuhiro, "Affording Expensive Ceremonies: Evidence from Quinceañeras in Mexico," 2021. Working Paper.

Tanck de Estrada, Dorothy, Atlas Illustrado de los Pueblos de Indios: Nueva España, 180o, Mexico City, Mexico: El Colegio de México, 2005.

Tanck de Estrada, Dorothy and Carlos Marichal, "¿Reino o Colonia?: Nueva España, 1750-1804," in Dorothy Tanck de Estrada and Carlos Marichal, eds., Nueva Historia General de México, Mexico City, Mexico: El Colegio de México, 2010, pp. 307-354.

Thaler, Richard and H. M. Shefrin, "An Economic Theory of Self-Control," Journal of Political Economy, 1981, 89 (2), 392-406.

Timmer, C. Peter, "The Agricultural Transformation," Handbook of Development Economics, 1998, 1, 276-328.

USDA, United States Department of Agriculture, "Commodity Intelligence Report: Mexico Corn: Adequate Reservoir Levels Benefitting Winter Corn," 2017. Foreign Agricultural Service Commodity Intelligence Report.

Valencia Caicedo, Felipe, "The Mission: Economic Persistence, Human Capital Transmission and Culture in South America," The Quarterly Journal of Economicsl, 2019, 134 (1), 507-556.

Wagner, Rodrigo, "Shutting Down Part of the Economy: The Causal Effect of Public Holidays on Growth," 2021. Working Paper.

Waldinger, Maria, "The Long-Run Effects of Missionary Orders in Mexico," Journal of Development Economics, 2017, 127 (1), 355-378.

Yang, Dean, "Why Do Migrants Return to Poor Countries? Evidence from Philippine Migrants' Responses to Exchange Rate Shocks," Review of Economics and Statistics, 2006, $88(4), 715-735$.

- and HwaJung Choi, "Are Remittances Insurance? Evidence from Rainfall Shocks in the Philippines," The World Bank Economic Review, 05 2007, 21 (2), 219-248.

Young, Alwyn, "Channeling Fisher: Randomization Tests and the Statistical Insignificance of Seemingly Significant Experimental Results," The Quarterly Journal of Economics, 2018, 134 (2), 557-598. 


\title{
Online Appendix for
}

\section{Religious Festivals and Economic Development: \\ Evidence from Catholic Saint-Day Celebrations in Mexico}

\author{
Eduardo Montero \\ Dean Yang \\ University of Chicago University of Michigan
}

15 January 2022 


\section{Contents}

Appendix A Data Appendix 3

A.1 Patron Saint and Festival Date Data . . . . . . . . . . . . . 3

A.1.1 Official Patron Saint Celebration Dates . . . . . . . . . . 3

A.1.2 Determining Patron Saints for Municipalities in Mexico: . . . 3

A.1.3 Coding Patron Saint Dates . . . . . . . . . . . . . 4

A.1.4 Information on "Renamed" Patron Saints . . . . . . . . . . 5

A.2 Geographic Data and Variables . . . . . . . . . . . . . . . 8

A.3 Mexico Census Data and Indexes . . . . . . . . . . . . . 10

A.4 Americasbarometer (LAPOP) Data and Indexes . . . . . . . . . . 12

$\begin{array}{ll}\text { Appendix B Additional Maps } & 14\end{array}$

B.1 Additional Maps - New Spain . . . . . . . . . . . . . . . . . . . . . . . 14

B.2 Additional Maps - All of Mexico . . . . . . . . . . . . . . . . . . 19

$\begin{array}{lr}\text { Appendix C Additional Figures } & 21\end{array}$

$\begin{array}{ll}\text { Appendix D Additional Tables } & \mathbf{2 6}\end{array}$

Appendix References 


\section{Appendix A. Data Appendix}

\section{A.1. Patron Saint and Festival Date Data}

As discussed in the main text, in our empirical analyses we assign patron saint celebration dates as prescribed by the Vatican (or, in a minority of cases, official religious sources outside of Mexico) so as to reduce concerns about the endogeneity of festival dates. In this section, we describe the sources we used to determine: 1) official patron saint celebration dates, and 2) the patron saint celebrated by each municipality.

\section{A.1.1. Official Patron Saint Celebration Dates}

1. a. We use three main sources to determine official patron saint celebration dates. $94.83 \%$ of municipalities have saints that are sourced using one of these three sources (in order of the frequency with which we used the source):

i. The General Roman Calendar (Calendarium Romanum) (Catholic Church, 1969):

- Catholic Church (1969). Calendarium Romanum (1969)

ii. The Roman Martyrology (Martirologio Romano) (Catholic Church, 1956):

- Catholic Church (1956). Martirologio Romano (1956)

iii. The Book of Saints (Watkins, 2015):

- Watkins, Basil. The Book of Saints: A Comprehensive Biographical Dictionary, Bloomsbury Publishing Plc (2015)

b. In a small number of cases an official patron saint celebration date was not found in the sources above. In these cases, we use a variety of online religious sources cited below. We ensured that we had least two online sources per saint. Only $3.44 \%$ of municipalities have saints that are sourced using online sources.

\section{A.1.2. Determining Patron Saints for Municipalities in Mexico:}

1. We use three primary sources to identify the patron saint of each municipality:

a. Encyclopedia: We use the online Encyclopedia of Municipalities (INAFED, 1988, available at http://www.inafed.gob.mx/work/ enciclopedia/) to determine the patron saint for approximately 1,900 of the municipalities in Mexico. 
b. Direct Phone Calls to Municipalities: We called approximately 300 municipalities to determine their patron saint. When calling municipalities, we first attempted to contact municipality government offices, followed by local churches and schools. To verify the accuracy of the information given to use over the phone, we also provide additional sources in the form of online links for over half of the "called" municipalities.

c. Additional Online Sources: In cases where we could not contact anyone with phone calls, and we did not find any information in the Encyclopedia, we used online sources such as news articles and government websites. We required at least two web sources before determining the saint. We use websites as sources for 180 municipalities.

\section{A.1.3. Coding Patron Saint Dates}

We used the following guidelines when coding patron saint dates:

i. We use a missing value code, 98 , to indicate that the festival is a "moving festival", one for which the official date differs from year to year. $4.19 \%$ of municipalities in Mexico have moving festivals, and are considered missing from our dataset for analysis.

ii. In cases where the festival is not moving but spans a few days we use the first date of the festival. For example, "Día de los Muertos" is a two-day festival from November 1-2. We use November $1^{\text {st }}$ as the official date. We assume that any diversion of resources, time, etc. due to a festival would have already happened by the first date of the range.

iii. In some cases, our research indicates that a municipality celebrates a particular Vatican-recognized saint, but has renamed it for the purpose of calling this saint their patron saint. In these cases, we consider the original Vatican-recognized saint as the municipality's saint, and use the Vatican-prescribe official celebration date (as usual). We detail these cases and the sources used to determine these "renamed" saints below in Section A.1.4.

iv. In some cases, municipalities in Mexico celebrate a "local" saint: a saint that is not recognized or celebrated outside of that municipality in Mexico. Because these saints might be endogenously selected, we provide a variable that codes whether or not a saint is a "local saint". The variable "local_saint" has three possible values: 0,1,2. A saint is coded as " $\mathrm{O}$ " if the official celebration date of a saint is set outside of Mexico. A saint is coded as " $I$ " if the saint is found to be specific to Mexico, and thus not have an official celebration date that is set outside of Mexico ( $1.67 \%$ of municipalities in Mexico). A “2" indicates 
the saint has indeterminate origins (1.71\% of municipalities in Mexico). (Our main analyses do not include municipalities with "local" saints, but we show robustness of our results to including them. When we include municipalities with local saints in our robustness analyses, we use celebration dates actually used by municipalities, since "official" Vatican-prescribed celebration dates do not exist for such saints.)

v. We use another missing value code, 99, to indicate a municipality where a saint was found in the encyclopedia or via phone calls but we were unable to find credible sources corroborating an official date or saint. This occurred in four municipalities across all of Mexico.

vi. We also use the missing value code 99 to represent municipalities for which we were unable to determine any Saint. In one municipality, this was because the municipality does not celebrate a patron saint. For the remaining 20 missing saint days, we were unable to determine a patron with credible online sources or phone calls.

\section{A.1.4. Information on "Renamed" Patron Saints}

Below, we detail the specific "renamed" saints that our research indicates are simply venerations of another official Vatican-recognized saint, the municipality code where they occur, and the sources used to determine this.

- Acatlan in Veracruz de Ignacio de la Llave (clave: 30002) celebrates la Virgen de los Remedios which is the same saint as la Natividad de Maria (Díaz 2018), (VistasGallery, n.d), (Sistema de Información Cultura 2021).

- Agualeguas in Nuevo Leon celebrates la Virgen de Agualeguas (clave: 19002) which is the same saint as la Virgen de la Concepcion (Nuevo Leon, n.d), (Nuevo Leon Turismo, n.d)

- Apizaco in Tlaxcala (clave: 29005) celebrates la Virgen de la Misericordia which is the same saint as la Virgen de las Mercedes (ACI Prensa 2020), (Aleteia 2019).

- Atlacomulco in Mexico (clave: 15014) celebrates el Senor del Huerto which is the same saint as Lunes Santo (Turismo Ejea, n.d).

- Atlamajalcingo del Monte in Guerrero (clave: 12009) celebrates la Virgen de Misericordia which is the same saint as la Virgen de las Mercedes (ACI Prensa 2020), (Aleteia 2019).

- Bustamante in Nuevo Leon (clave: 19008) celebrates Santo Cristo (el Senor de Tlaxcala) which is the same saint as el Transfiguracion del Senor (Lemus 2016), (Pueblos Mágicos, n.d), (Villarreal 2006). 
- Canitas de Felipe Pescador in Zacatecas (clave: 32006) celebrates la Virgen de San Juan which is the same saint as la Asuncion de Maria (Holy Family Catholic Church, n.d), (Library of Congress, n.d), (IMER 1970).

- Charcas in San Luis Potosi (clave: 24015) celebrates la Virgen de las Charcas which is the same saint as Natividad de Maria (EichmannOehrli 2004), (De la Rosa, 2020).

- Compostela in Nayarit (clave: 18004) celebrates la Virgen de la Misericordia which is the same saint as la Virgen de las Mercedes (ACI Prensa 2020), (Aleteia 2019).

- Cunduacan in Tabasco (clave: 27006) celebrates el Senor de la Salud which is the same saint as Cristo de la Salud (Valdemoro Turismo 2020).

- Emiliano Zapata in Hidalgo (clave: 13021) celebrates la Virgen de San Juan de los Lagos which is the same saint as la Asuncion de Maria (Holy Family Catholic Church, n.d), (Library of Congress, n.d), (IMER 1970).

- Espita in Yucatan (clave: 31032) celebrates el Nino Jesus which is the same saint as Nino de Atocha (Rodriguez 2018), (Sistema de Información Cultural de Costa Rica 2021), (Divino Nino Jesus Catholic Mission 2021)

- Huamantla in Tlaxcala (clave: 29013) celebrates la Virgen de la Caridad which is the same saint as Natividad de Maria (ZENIT 2014), (Ruiz Scaperlanda, 2007), (Lamas 2004).

- Huatlatlauca in Puebla (clave: 21070) celebrates Nuestra Senora de los Reyes which is the same saint as Asuncion de Maria (Catedral de Sevilla 2020), (Real Hermandad de Nuestra Senora de los Reyes, n.d), (Catedral de Sevilla 2020), (A.VRyS, n.d).

- Huiramba in Michoacan de Ocampo (clave: 16039) celebrates el Nino Jesus which is the same saint as Nino de Atocha (Rodriguez 2018), (Sistema de Información Cultural de Costa Rica 2021), (Divino Nino Jesus Catholic Mission 2021).

- Izamal in Yucatan (clave: 31040) celebrates la Virgen de Izamal which is the same saint as Virgen de la Concepcion (SSVM, n.d), (Yucatan Today 2019), (Pueblos Mágicos, n.d).

- Jonuta in Tabasco (clave: 27011) celebrates el Senor de la Salud which is the same saint as Cristo de la Salud (Valdemoro Turismo 2020).

- La Concordia in Chiapas (clave: 7020) celebrates la Virgen de la Misericordia which is the same saint as la Virgen de las Mercedes (ACI Prensa 2020), (Aleteia 2019). 
- Los Reyes de Juarez in Puebla (clave: 21118) celebrates Nuestra Senora de los Reyes which is the same saint as Asuncion de Maria (Catedral de Sevilla 2020), (Real Hermandad de Nuestra Senora de los Reyes, n.d), (Catedral de Sevilla 2020), (A.VRyS, n.d).

- Monterrey in Nuevo Leon (clave: 19039) celebrates la Virgen del Roble which is the same saint as la Virgen de la Esperanza (Díaz 2017), (de Cos 2018).

- Nacajuca in Tabasco (clave: 27013) celebrates la Virgen de los Remedios which is the same saint as la Natividad de Maria (Díaz 2018), (VistasGallery, n.d), (Sistema de Información Cultura 2021).

- Naucalpan de Juarez in Mexico (clave: 15057) celebrates la Virgen de los Remedios which is the same saint as La Natividad de Maria (Díaz 2018), (VistasGallery, n.d), (Sistema de Información Cultura 2021).

- Ocotlan in Jalisco (clave: 14063) celebrates la Virgen de la Misericordia which is the same saint as la Virgen de las Mercedes (ACI Prensa 2020), (Aleteia 2019).

- Oteapan in Veracruz de Ignacio de la Llave (clave: 30120) celebrates el Senor de la Salud which is the same saint as Cristo de la Salud (Valdemoro Turismo 2020).

- Patzcuaro in Michoacan de Ocampo (clave: 16066) celebrates la Virgen de la Salud which is the same saint as Virgen de la Concepcion (Roman Catholic Diocese of Chalan Kanoa 2018), (Pátzcuaro Info 2020).

- Reyes Etla in Oaxaca (clave: 20077) celebrates Nuestra Senora de los Reyes which is the same saint as la Asuncion de Maria (Catedral de Sevilla 2020), (Real Hermandad de Nuestra Senora de los Reyes, n.d), (Catedral de Sevilla 2020), (A.VRyS, n.d).

- Sabanilla in Chiapas (clave: 7076) celebrates la Virgen de la Misericordia which is the same saint as la Virgen de las Mercedes (ACI Prensa 2020), (Aleteia 2019).

- San Juan Juquila Mixes in Oaxaca (clave: 20200) celebrates la Virgen de Juquila which is the same saint as la Virgen de la Concepcion (St. Mary Parish 2018), (Ramirez 2019), (Jiménez 2020).

- San Juan del Rio in Durango (clave: 10028) celebrates la Virgen de los Remedios which is the same saint as la Natividad de Maria (Díaz 2018), (VistasGallery, n.d), (Sistema de Información Cultura 2021).

- San Pedro Cholula in Puebla (clave: 21140) celebrates la Virgen de los Remedios which is the same saint as la Natividad de Maria (Díaz 2018), (VistasGallery, n.d), (Sistema de Información Cultura 2021). 
- Soyalo in Chiapas (clave: 7085) celebrates la Virgen de la Caridad which is the same saint as la Natividad de Maria (ZENIT 2014), (Ruiz Scaperlanda, 2007), (Lamas 2004).

- Tamazula de Gordiano in Jalisco (clave: 14085) celebrates la Virgen del Sagrario which is the same saint as la Asuncion de Maria (Revista Catedral 1970), (Catedral Primada, n.d).

- Tamiahua in Veracruz de Ignacio de la Llave (clave: 30151) celebrates La Virgen de la Misericordia which is the same saint as la Virgen de las Mercedes (ACI Prensa 2020), (Aleteia 2019).

- Tepatitlan de Morelos in Jalisco (clave: 14093) celebrates la Virgen de la Misericordia which is the same saint as la Virgen de las Mercedes (ACI Prensa 2020), (Aleteia 2019).

- Tepic in Nayarit (clave: 18017) celebrates la Virgen en su Santuario which is the same saint as la Virgen de Guadalupe (Nayarit en Linea 2013), (Shrine of Our Lady of Guadalupe, 2021), (Nayarit Enamora, n.d) (NNC 2016), (Presa 2019).

- Tlalnepantla de Baz in Mexico (clave: 15104) celebrates la Virgen de la Misericordia which is the same saint as la Virgen de las Mercedes (ACI Prensa 2020), (Aleteia 2019).

- Tonanitla in Mexico (clave: 15125) celebrates la Virgen de los Remedios which is the same saint as la Natividad de Maria (Díaz 2018), (VistasGallery, n.d), (Sistema de Información Cultura 2021).

- Tototlan in Jalisco (clave: 14105) celebrates el Senor de la Salud which is the same saint as Cristo de la Salud (Valdemoro Turismo 2020).

- Union de San Antonio in Jalisco (clave: 14109) celebrates la Virgen de la Misericordia which is the same saint as la Virgen de las Mercedes (ACI Prensa 2020), (Aleteia 2019).

- Villa Union in Coahuila de Zaragoza (clave: 5037) celebrates el Nino de los Peyotes which is the same saint as Dulce Nombre de Jesus (Telepaisa, n.d), (ACI Prensa 2021).

- Zacatecas in Zacatecas (clave: 32056) celebrates la Virgen del Patrocinio which is the same saint as la Natividad de Maria (EcuRed, n.d), (Manresa Ignacio Abadal 1800).

- Zihuateutla in Puebla (clave: 21213) celebrates Manuelito which is the same saint as Corpus Cristi (El Caminante 2019), (Presidencia Municipal de Zihuateutla, n.d).

\section{A.2. Geographic Data and Variables}

- Precipitation and Temperature: Precipitation and temperature data are provided by the Global Climate Database created by Hijmans et al. (2005) 
and available at http://www.worldclim.org/. These data provide monthly average rainfall in millimeters. We calculate the average rainfall for each month in each municipality and average this over the twelve months to obtain our yearly precipitation measure in millimeters of rainfall per year. Similarly, we calculate the average temperature for each month in each municipality and average this over the twelve months to obtain our yearly temperature measure in centigrades.

- Land Suitability: Land suitability is the soil component of the land quality index created by the Atlas of the Biosphere available at http://www.sage. wisc.edu/iamdata/ used in Michalopoulos (2012) and Ramankutty et al. (2002). These data use soil characteristics (namely soil carbon density and the acidity or alkalinity of soil) and combines them using the best functional form to match known actual cropland area and interpolates this measure to be available for most of the world at the 0.5 degree in latitude by longitude level. This measure is normalized to be between o and 1 , where higher values indicate higher soil suitability for agriculture.

- Maize Suitability: Maize suitability is the average suitability for rain-fed, low-input crops provided by the FAO's Global Agro-Ecological Zones website: http://www.iiasa.ac.at/Research/LUC/GAEZ/index.htm (Fischer et al., 2012). FAO crop suitability model uses data on elevation, precipitation, soil and slope constraints to construct estimates of crop suitability at the 1 $\mathrm{km}^{2}$ level for different crops. We normalized the measure to be between o and 100, where higher values indicate higher crop suitability.

- Elevation and Slope: The elevation and slope data are provided by the Global Climate Database created by Hijmans et al. (2005) and available at http://www.worldclim.org/. These data provide elevation information in meters at the 30 arc-second resolution (approximately at the $1 \mathrm{~km}^{2}$ level near the equator). The elevation measure is constructed using NASAs SRTM satellite images (http://www2.jpl.nasa.gov/srtm/).

- Municipal Area, Longitude, Latitude, and Distance to Mexico City: To calculate these municipal variables, we use geographic shapefiles provided by INEGI for municipal boundaries in Mexico: https://www.inegi.org.mx/ temas $/ \mathrm{mg} /$. Municipal area is calculated as the total area of a municipality in $\mathrm{km}^{2}$. Municipal longitude and latitude correspond to the longitude and latitude of the municipalities centroid. Distance to Mexico City is defined as the distance in $\mathrm{km}$ from a municipality's centroid to Mexico City. 


\section{A.3. Mexico Census Data and Indexes}

- Population Census: We use municipality-level data from the 2010 Censo de Población y Vivienda produced by the National Institute of Statistics and Geography (INEGI) of Mexico. For more information on this census, see INEGI documentation at https://www.inegi.org.mx/programas/ccpv/2010/. This census interviewed households with over 106 million total inhabitants across Mexico about their economic well-being, labor supply, asset ownership, and education. We construct an index of economic development using all questions in the census related to economic development within a municipality. We construct the index as the first principal component of these measures of development. Figure 5 presents the components of this index. The index includes all questions on educational attainment, workforce participation, literacy, asset and ownership. We list each index component and its definition below:

- Log Population: This measures the log of the number of inhabitants for each municipality in 2010.

- Log Household Income: To construct a measure of household income, we use the IPUMS 10\% sample and take the log of each adult respondent's household income. ${ }^{51}$ We then construct the average for each municipality.

- \% Economically Active: Share of a municipality's population that is "economically active", defined by INEGI as: in a given reference week (e.g. previous week), an individual over 12 years of age performed any work (including informal work), had a job but did not work, or were actively looking for work.

- \% Economically Active - Men: Share of a municipality's population of men over 12 years of age that is economically active.

- \% Economically Active - Women: Share of a municipality's population of women over 12 years of age that is economically active.

- \% Employed: Share of a municipality's population that is "economically occupied", defined by INEGI as: in a given reference week, an individual over 12 years of age performed any work (including informal work) or had a job but did not work.

- \% Literate - Aged 8-14: Share of a municipality's population of individuals aged between 8 and 14 years that know how to read and write.

- \% Literate - Aged over 14 Years: Share of a municipality's population of individuals aged over 14 years that know how to read and write.

\footnotetext{
${ }^{51}$ The INEGI municipality-level extract does not include this, but we were able to construct this using the IPUMS extract.
} 
- Average Years of Education - All: Average years of education for a municipality's population aged over 15 years.

- Average Years of Education - Men: Average years of education for a municipality's population of men aged over 15 years.

- Average Years of Education - Women: Average years of education for a municipality's population of women aged over 15 years.

- \% in School - Aged 3-5: Share of a municipality's population of children between the ages of 3 and 5 that attend at least some school in a year.

- \% in School - Aged 6-11: Share of a municipality's population of children between the ages of 6 and 11 that attend at least some school in a year.

- \% in School - Aged 12-14: Share of a municipality's population of individuals between the ages of 12 and 14 that attend at least some school in a year.

- \% in School - Aged 15-17: Share of a municipality's population of individuals between the ages of 15 and 17 that attend at least some school in a year.

- \% in School - Aged 18-24: Share of a municipality's population of individuals between the ages of 18 and 24 that attend at least some school in a year.

- \% with Some Schooling: Share of a municipality's population over 15 years of age that has attended at least some schooling in their lifetime.

- \% Completed Primary Education: Share of a municipality's population over 15 years of age that has completed primary education (6 years).

- \% Completed Secondary Education: Share of a municipality's population over 15 years of age that has completed secondary education. (3 additional years)

- \% Completed College: Share of a municipality's population over 18 years of age that has completed any form of post-secondary schooling.

- \% with At Least Some Primary Education: Share of a municipality's population over 15 years of age that has at least attended and completed some primary education (>o years of schooling).

- \% with At Least Some Secondary Education: Share of a municipality's population over 15 years of age that has at least attended and completed some secondary education ( $>6$ years of schooling).

- \% Own Radio(s): Share of a municipality's households that own at least one radio. 
- \% Own Television(s): Share of a municipality's households that own at least one television.

- \% Own Refrigerator(s): Share of a municipality's households that own at least one refrigerator.

- \% Own Washing Machine(s): Share of a municipality's households that own at least one washing machine.

- \% Own Car(s): Share of a municipality's households that own at least one car.

- \% Own Computer(s): Share of a municipality's households that own at least one computer.

- \% Own Telephone(s): Share of a municipality's households that own at least one telephone (landline).

- \% Own Cellphone(s): Share of a municipality's households that own at least one cellphone.

- \% with Paved Floor: Share of a municipality's households that have non-dirt floors in their households (e.g. cement, wood, tiled, or other).

- \% with Electricity: Share of a municipality's households that have access to electric-powered light at their home.

- \% with Plumbing: Share of a municipality's households that have water accessed through plumbing from the government ("public network") in their home.

- \% with Toilets: Share of a municipality's households that have toilets at their home.

- \% with Internet: Share of a municipality's households that have access to the internet at their home.

\section{A.4. Americasbarometer (LAPOP) Data and Indexes}

- Data: we use survey data from the Americasbarometer from 2004 to 2018. To examine differences in religiosity, we construct an index from three questions related to religiosity: the importance of religion to an individual, church attendance, and religious group attendance. We construct our index as the first principal component of these questions; we describe each question/component below.

- Importance of Religion: is a 1-4 categorical variable that measures how important religion is to a respondent, ranging from $1=$ "Not Important at All" to 4="Very Important". 
- Church Attendance: is a 1-4 categorical variable that measures how frequently an individual goes to church, where $1=$ "Never", $2=$ "Once or Twice a Year", 3="Once or Twice a Month", and 4="Once a Week".

- Religious Group Attendance: is a 1-4 categorical variable that measures how frequently an individual participates in religious group meetings, ranging from $1=$ "Never" to $4=$ "Once a Week".

To examine differences in social capital, we construct an index using questions related to the frequency of attending various group meetings. We include questions on the following groups: community improvement groups, parent associations, municipal meetings, or political associations..$^{2}$ Each group meeting question is a 1-4 categorical variable that measures how frequently an individual goes to meetings for each group - where $1=$ "Never", $2=$ "Once or Twice a Year", 3="Once or Twice a Month", and 4="Once a Week" - except for municipal meetings, which is an indicator variable equal to $I$ if the respondent attends municipal meetings. We construct our index as the first principal component of these questions.

${ }^{2}$ These are the groups listed in each wave of the data. 


\section{Appendix B. Additional Maps}

\section{B.1. Additional Maps - New Spain}

Figure B1: Saint Day Festival Months: New Spain Region of Mexico

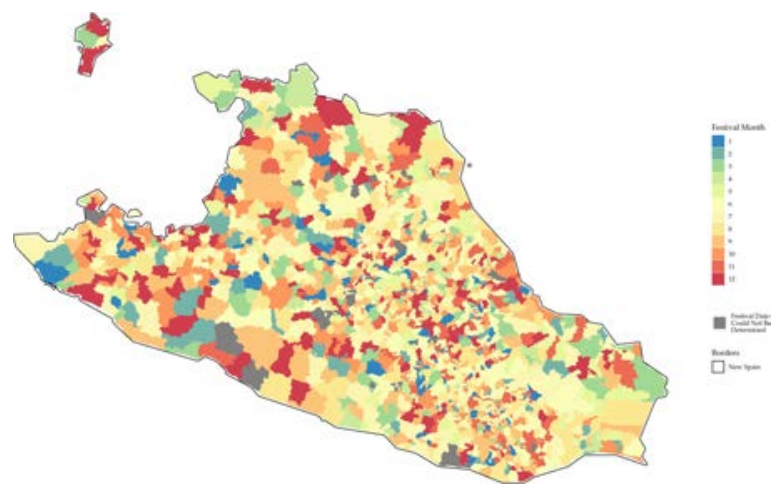

Notes: The map presents the month that each municipality in the New Spain region of Mexico celebrates its respective Catholic patron saint day festival. Municipalities where we were unable to determine the festival date are shaded in dark grey. Borders of New Spain region of colonial Mexico are as defined by Gerhard (1993). See Appendix A.1 for more information on the construction of the festival date dataset. 
Figure B2: Maize Planting Month (FAO data):

New Spain Region of Mexico

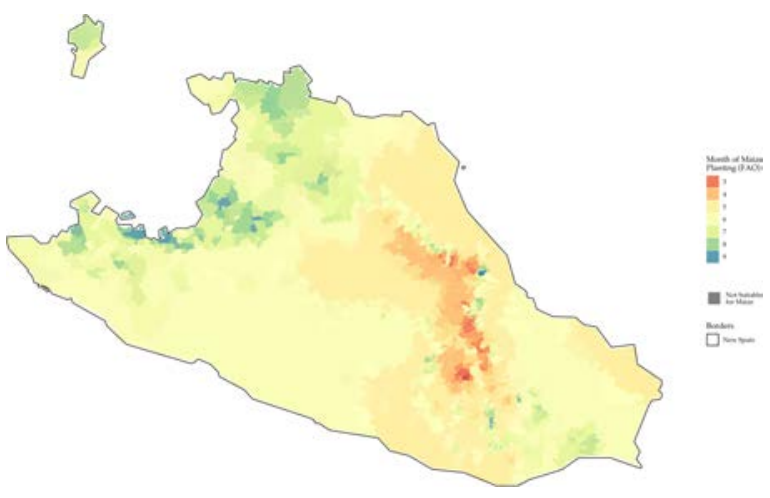

Notes: Optimal maize planting month according to FAO GAEZ data in the New Spain region of Mexico.

Figure B3: Maize Harvest Month (FAO data):

New Spain Region of Mexico

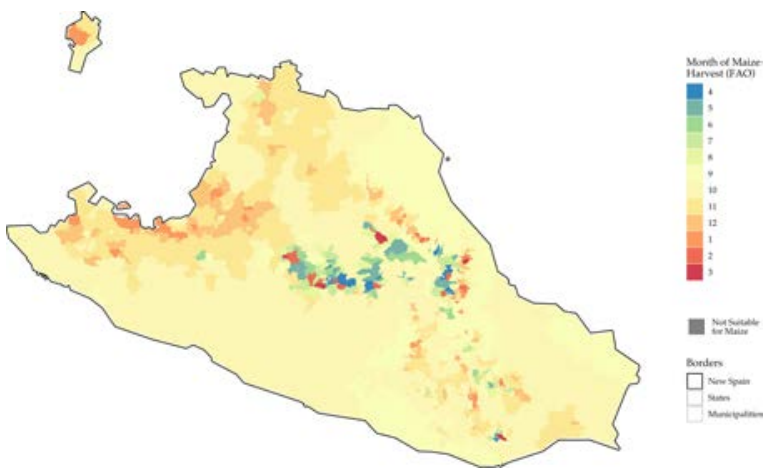

Notes: Optimal maize harvest month according to FAO GAEZ data in the New Spain region of Mexico. 
Figure B4: Days Between Festival and Optimal Planting Date: New Spain Region of Mexico

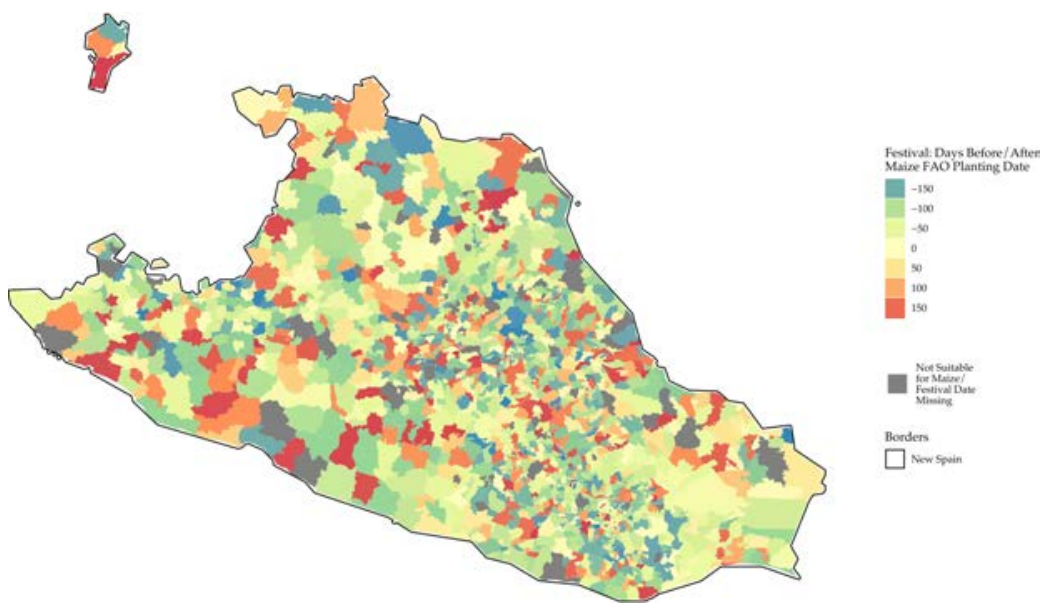

Notes: Difference (in days) between the patron saint day festival date and the optimal maize planting date (from FAO GAEZ data) for each municipality in the New Spain region of Mexico. (Negative values correspond to festivals that occur before planting; positive values correspond to festivals that occur after planting.) Municipalities where we were unable to determine the festival date are shaded in dark grey. 
Figure B5: Days Between Festival and Optimal Harvest Date:

New Spain Region of Mexico

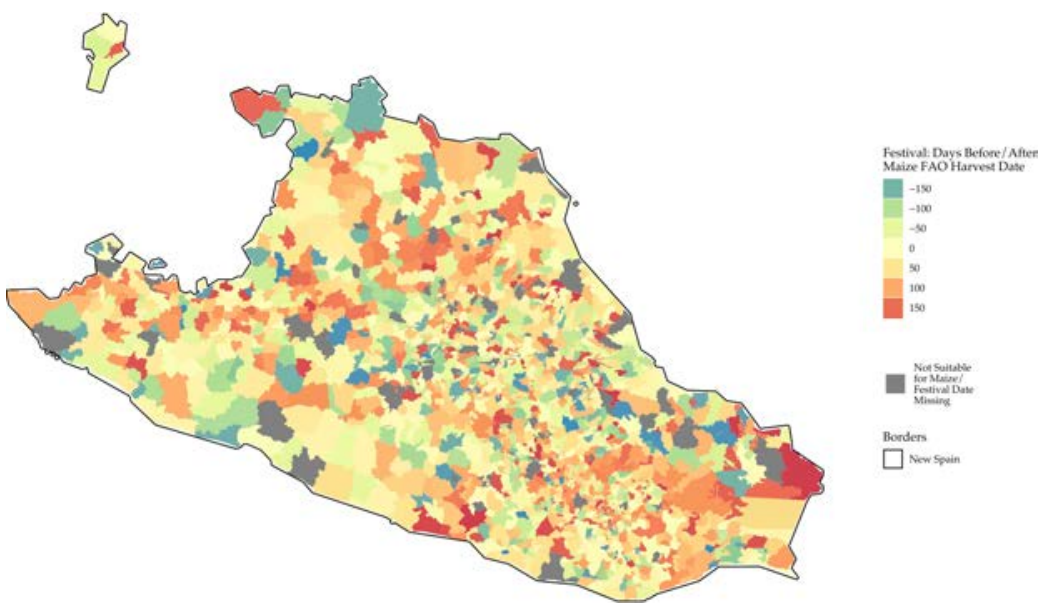

Notes: Difference (in days) between the patron saint day festival date and the optimal maize harvest date (from FAO GAEZ data) for each municipality in the New Spain region of Mexico. (Negative values correspond to festivals that occur before harvest; positive values correspond to festivals that occur after harvest.) Municipalities where we were unable to determine the festival date are shaded in dark grey.

Figure B6: Coincidence of Festivals and Optimal Planting Month: New Spain Region of Mexico

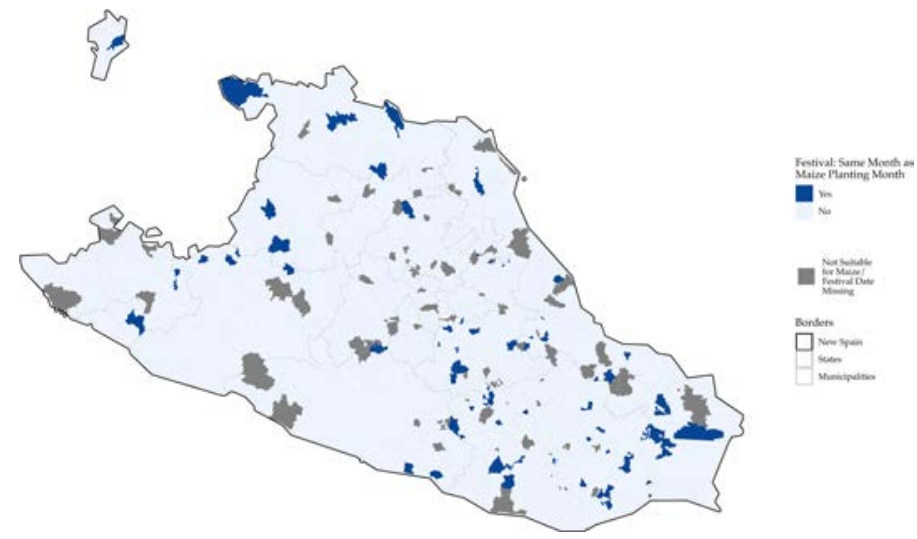

Notes: The map presents whether the month that each municipality in the New Spain region of Mexico celebrates its respective patron saint day festival falls o-3o days prior to the optimal maize planting date according to FAO GAEZ data. Municipalities where we were unable to determine the festival date are shaded in dark grey. 
Figure B7: Coincidence of Festivals and Optimal Harvest Month: New Spain Region of Mexico

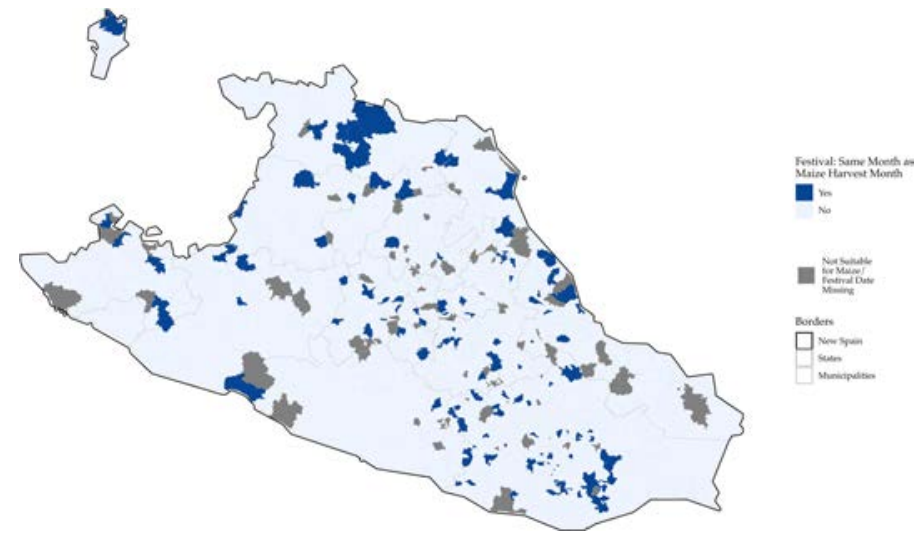

Notes: The map presents whether the month that each municipality in the New Spain region of Mexico celebrates its respective patron saint day festival falls o-30 days after the optimal maize harvest date according to FAO GAEZ data. Municipalities where we were unable to determine the festival date are shaded in dark grey. 


\section{B.2. Additional Maps - All of Mexico}

Figure B8: Maize Planting Date (FAO data)

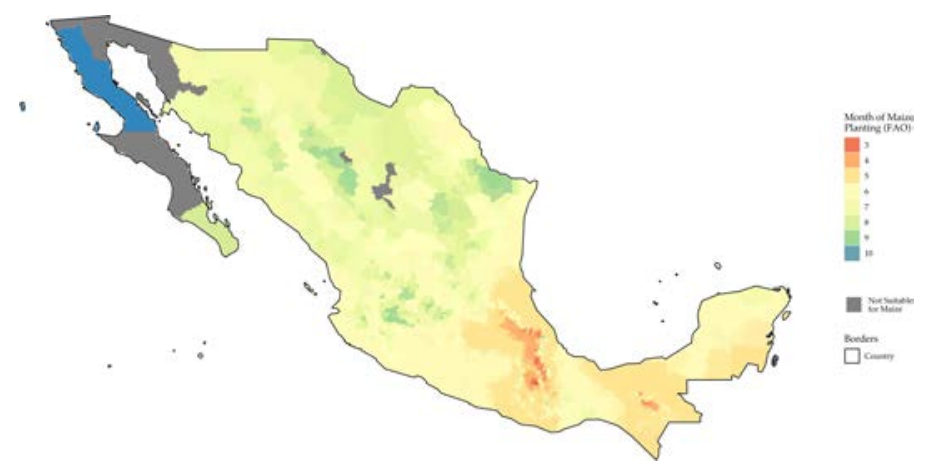

Notes: Optimal maize planting month according to FAO GAEZ data for each municipality in Mexico.

Figure B9: Maize Harvest Date (FAO data)

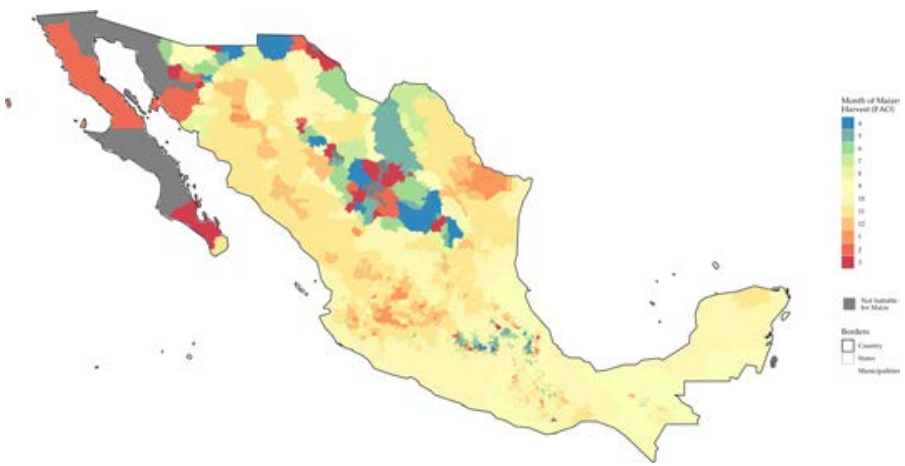

Notes: Optimal maize harvest month according to FAO GAEZ data for each municipality in Mexico. 
Figure B10: Coincidence of Festivals and Optimal Planting Month

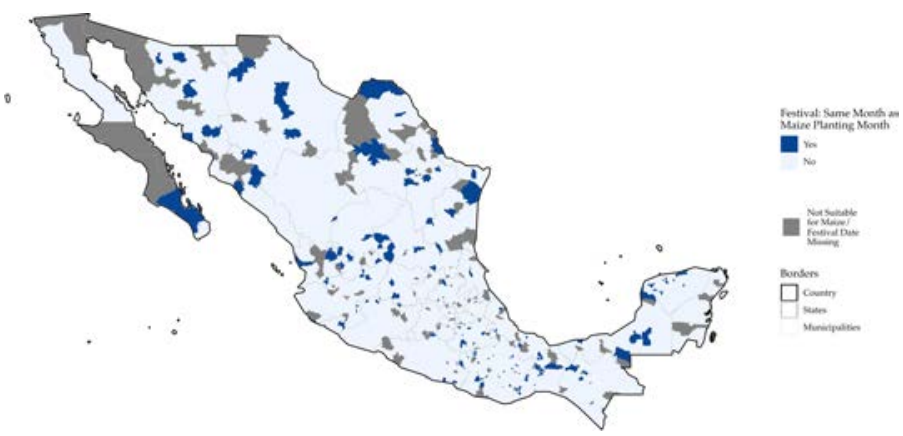

Notes: The map presents whether the date that each municipality in Mexico celebrates its respective patron saint day festival falls o-30 days prior to the optimal maize planting date according to FAO GAEZ data. Municipalities where we were unable to determine the festival date or are unsuitable for maize are shaded in dark grey.

Figure B11: Coincidence of Festivals and Optimal Harvest Month

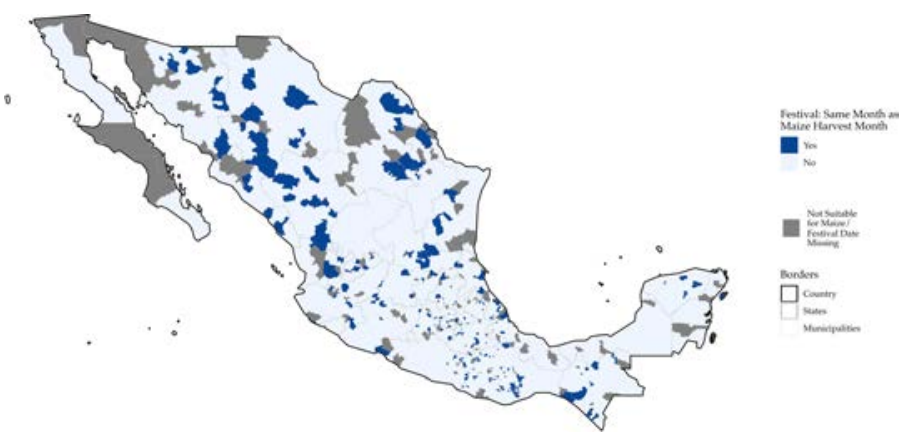

Notes: The map presents whether the date that each municipality in Mexico celebrates its respective patron saint day festival falls o-30 days after the optimal maize harvest date according to FAO GAEZ data. Municipalities where we were unable to determine the festival date or are unsuitable for maize are shaded in dark grey. 
Figure B12: Agriculturally-Coinciding Festivals

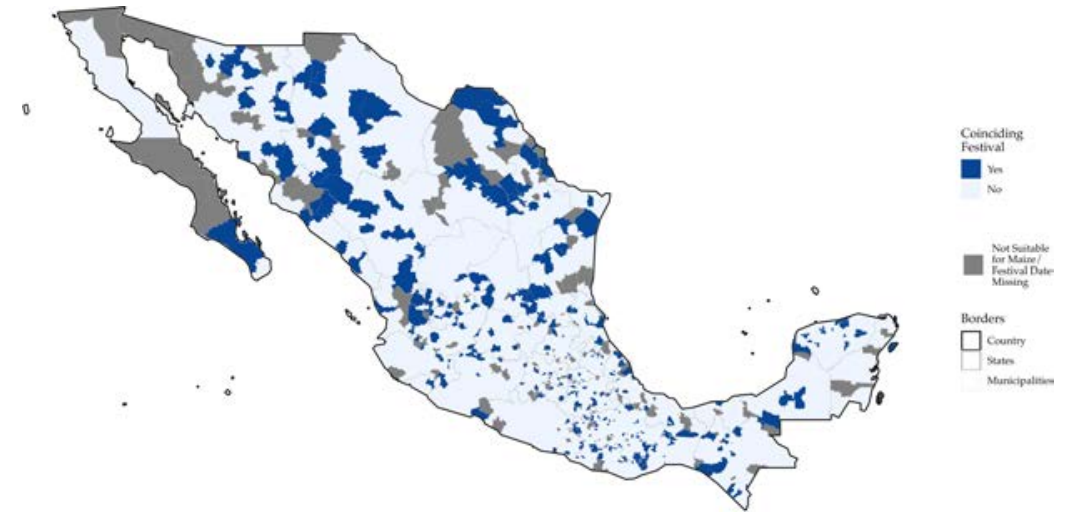

Notes: Coinciding Festival is equal to "Yes" if the saint day festival in a municipality occurs either o to 30 days prior to the optimal maize planting date or o to 30 days after the optimal maize harvest date for a municipality using FAO GAEZ data and "No" otherwise for each municipality in Mexico. Municipalities where we were unable to determine the festival date or are unsuitable for maize are shaded in dark grey.

\section{Appendix C. Additional Figures}


Figure $C_{1}$ : Validating Crop Calendar Data:

\section{Relationship Between Predicted Maize Harvest Timing and Actual Maize Harvest}

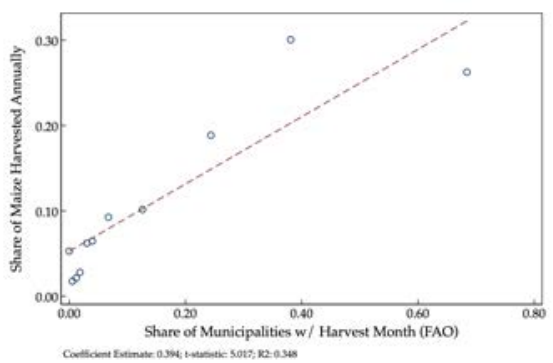

a. New Spain Region

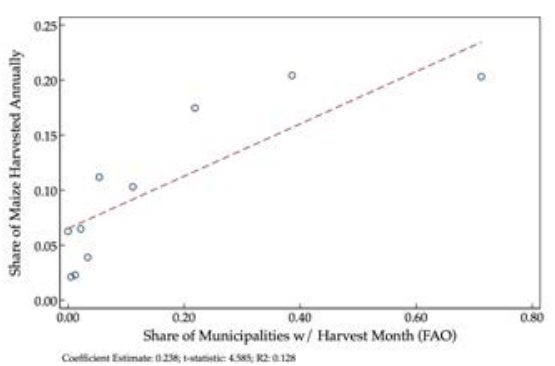

b. All of Mexico

Notes: The figure presents binscatters between the share of a state's total maize harvest that occurs on a given month and the share of municipalities in a state that have their maize harvest on a given month according to the FAO GAEZ data. The unit of observation is a state-month pair. State harvest Data are from the Servicio de

Información Agroalimentaria y Pesquera (SIAP) for 2015. The bottom-right of each figure presents the estimated bivariate coefficient, $t$-statistic, and $R^{2}$. Standard errors are clustered at the state level.

\section{Figure C2: Randomization Inference Exercise - Placebo Festivals}

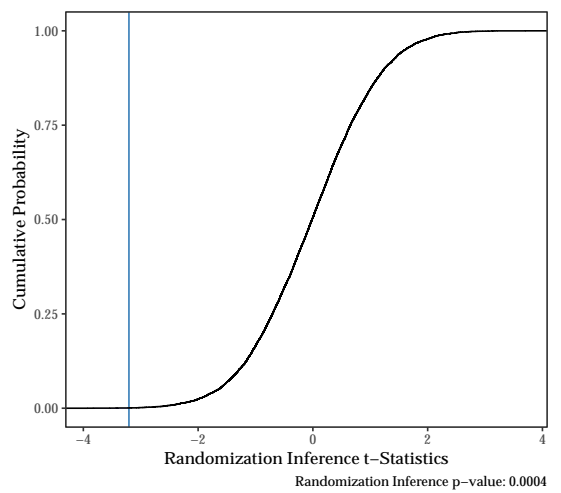

Notes: The figure presents the cumulative distribution function for the estimated t-statistics for the randomization inference exercise. Specifically, we conduct 10,000 simulations where we randomly assign whether or not a festival coincides with planting or harvest for each municipality and estimate our main specification, and then plot the cumulative distribution function for the estimated $t$-statistics. The dependent variable is Log Household Income. All regressions include state fixed effects, Geography Controls, Colonial Controls, Festival-Week Fixed Effects, and Planting- \& Harvest-Month Fixed Effects. Observations are municipalities in the New Spain region of Mexico. Additionally, the figure presents the estimated t-statistic for our sample, and reports the randomization inference $p$-value on the bottom right of the figure. 
Figure C3: Impact of Coinciding Festivals on Religiosity and Social Capital:

Estimates for Religiosity Index and Group Membership Index Components

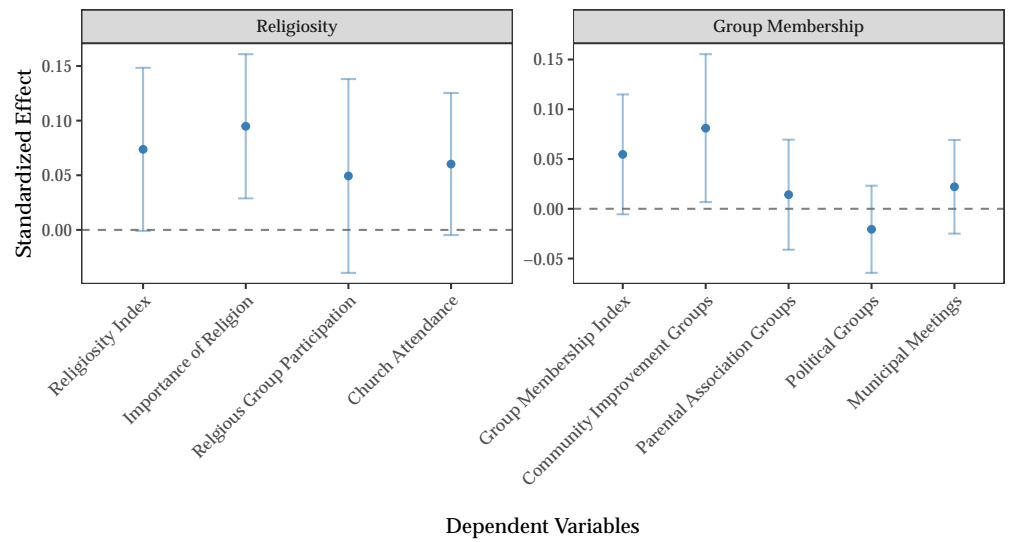

Notes: Data are from the Americas Barometer (LAPOP) data for New Spain region of Mexico. The figure presents the estimated coefficients and respective $95 \%$ confidence intervals from estimating equation (1) on the sub-components of the Religiosity Index and the Group Membership Index. The dependent variables are denoted on the x-axis. We first show the estimates for each index, followed by estimates for each of the individual sub-components of the index. (See Data Appendix for more information.) The independent variable is Festival Coincides with Maize Planting or Harvest: an indicator variable equal to 1 if the saint day festival in a municipality occurs either o to 30 days prior to the optimal maize planting date or o to 30 days after the optimal maize harvest date for a municipality using FAO GAEZ data. The regressions control for respondent age, age squared, gender, and for the following set of controls: Survey-Wave Fixed Effects, State Fixed Effects, Geography Controls, Colonial Controls, Festival-Week Fixed Effects, and Planting- \& Harvest-Month Fixed Effects.

\section{Sensitivity to 3o-Day Window Used to Define Coinciding with Planting or Har- vest Months}

We vary the 30-day window (relative to planting and harvest) used to estimate our main specification and examine when the negative impacts of festivals seem to arise. Specifically, in equation ( 1 ), we focus on the periods when having a festival coincide with planting/harvest may lead to lower long-run development: periods when festival expenditures may crowd out agricultural labor time and investments. We defined these periods as being 0-30 day prior to planting and o-30 after harvest. However, there are many other 30-day windows one could use to define these overlap periods. Thus, we conduct an exercise to explore the timing of the main impacts by varying the 30-day window across time and estimating our main impacts. To conduct this exercise we estimate the following specification:

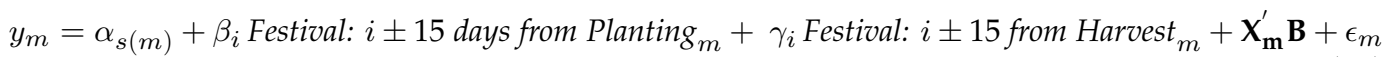

where our coefficients of interest are $\beta_{i}$ and $\gamma_{j}$, the effect of festivals occurring $i \pm 15$ days from planting or harvest for various values of $i$; and other variables are defined as before in equation (1). In other words, equation (AI) estimates our main specification but instead uses various rolling 30-day windows relative to planting and harvest. 
Figure $\mathrm{C}_{4}$ presents the coefficient plot for the estimates of interest from estimating equation (A1) on log household income used in Table 2. The estimates suggest an interesting time dimension to the impacts of festivals on development. First, the negative estimated effects of festivals coinciding with planting appear for various rolling windows prior to planting but converge toward zero following planting. Second, we observe the opposite timing for harvest festivals: the negative estimated effects of festivals coinciding with harvest only begin to appear following harvest (and are statistically insignificant and close to zero prior to harvest). Additionally, the estimates show that the main results are not particularly sensitive to the specific 30-day window we consider. These results are consistent with the hypotheses that the timing of festivals is important for understanding their development consequences, and that festivals can crowd out investments and decrease development when they occur in times of when time-sensitive economic opportunities exist. 


\section{Figure $\mathrm{C}_{4}$ : Impacts of Festival Timing Relative to Planting and Harvest Dates}

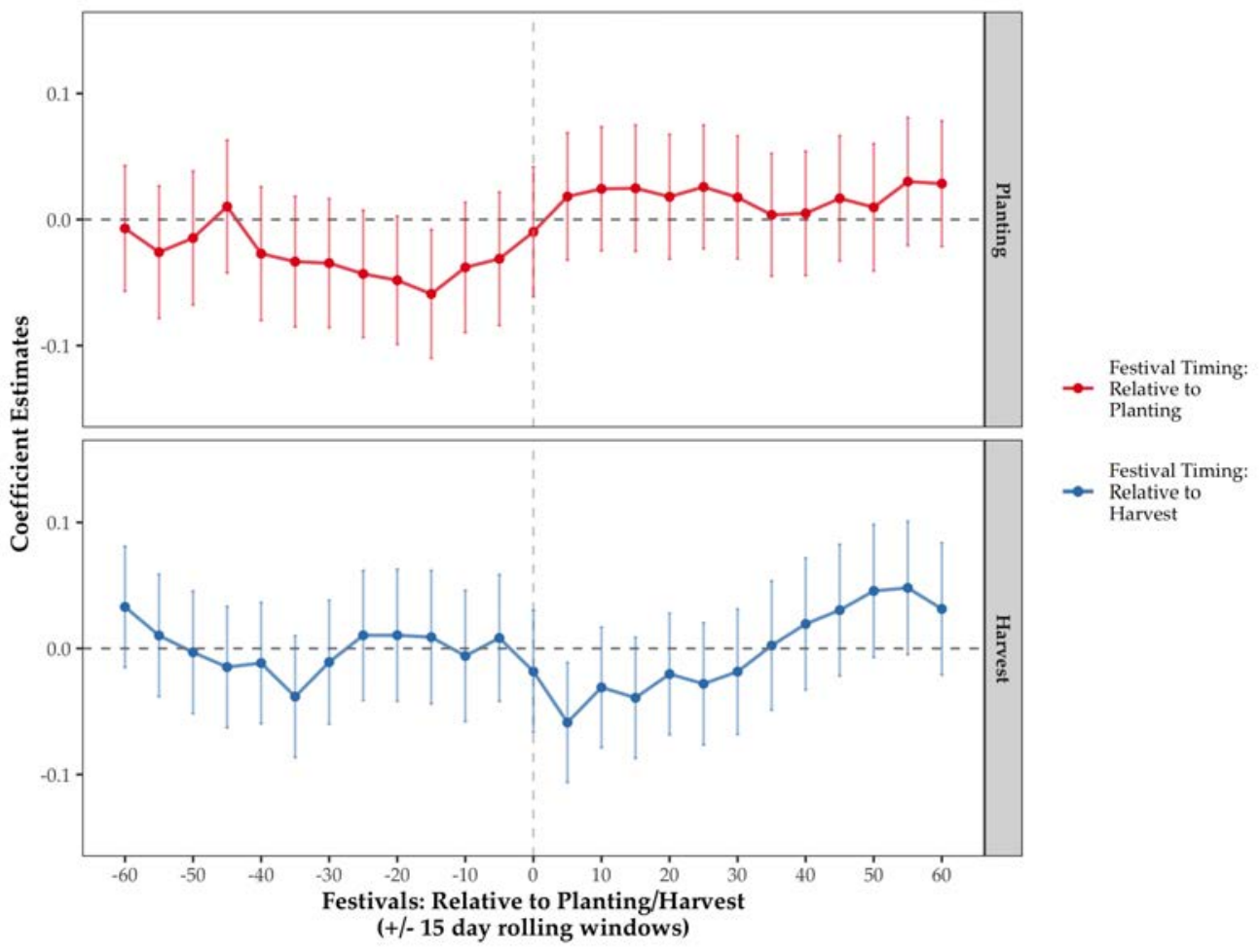

Notes: Data are from the 2010 Mexico Population Census for the New Spain region of Mexico. The figure presents the estimated $\beta_{i}$ (top panel) and $\gamma_{i}$ (bottom panel) coefficients and respective $95 \%$ confidence intervals from estimating equation (A1) for $i \in-60,60$ days. The outcome variable is Log Household Income. Festival : $i \pm 15$ days from Planting (top panel) is an indicator variable equal to 1 if the festival occurs $i \pm 15$ from the optimal planting date according to FAO GAEZ data (where negative values of $i$ means that the festival occurs prior to planting); Festival $: i \pm 15$ days from Harvest (bottom panel) is an indicator variable equal to 1 if the festival occurs $i \pm 15$ from the optimal harvest date according to FAO GAEZ data (where negative values of $i$ means that the festival occurs prior to harvest). The regressions control for the full-set of controls: State Fixed Effects, Geography Controls, Colonial Controls, Festival-Week Fixed Effects, and Planting- \& Harvest-Month Fixed Effects. 


\section{Appendix D. Additional Tables}

Table D1: Relationship Between Festival, Planting, and Harvest Months: All of Mexico

\begin{tabular}{|c|c|c|c|c|}
\hline & \multirow{2}{*}{\multicolumn{4}{|c|}{$\begin{array}{c}\text { Dependent Variable: } \\
\text { Festival Date }\end{array}$}} \\
\hline & & \\
\hline & $(1)$ & $(2)$ & $(3)$ & $(4)$ \\
\hline Maize Planting or Harvest Month & $\begin{array}{l}0.001 \\
(0.015) \\
{[0.016]}\end{array}$ & $\begin{array}{c}0.003 \\
(0.016) \\
{[0.016]}\end{array}$ & & \\
\hline Maize Planting Month & & & $\begin{array}{c}0.003 \\
(0.019) \\
{[0.019]}\end{array}$ & $\begin{array}{c}0.014 \\
(0.021) \\
{[0.020]}\end{array}$ \\
\hline Maize Harvest Month & & & $\begin{array}{c}-0.001 \\
(0.023) \\
{[0.024]}\end{array}$ & $\begin{array}{c}-0.009 \\
(0.024) \\
{[0.024]}\end{array}$ \\
\hline Calendar Date Fixed Effects & Y & $\mathrm{N}$ & $\mathrm{Y}$ & $\mathrm{N}$ \\
\hline Date by State Fixed Effects & $\mathrm{N}$ & Y & $\mathrm{N}$ & $\mathrm{Y}$ \\
\hline Observations & 833,382 & 833,382 & 833,382 & 833,382 \\
\hline Clusters & 2,277 & 2,277 & 2,277 & 2,277 \\
\hline Mean Dep. Var. & 0.273 & 0.273 & 0.273 & 0.273 \\
\hline $\begin{array}{l}\text { Notes: Observations are at the municip } \\
\text { have festival data. Standard errors clus } \\
\text { and Conley (1999) standard errors cal } \\
\text { brackets. For ease of interpretation, all } \\
\text { Month is an indicator variable equal to } 1 \\
\text { planting date or } 0 \text { to } 30 \text { days after the opt } \\
\text { data.Maize Planting Month is an indicatc } \\
\text { to the optimal maize planting date for a } \\
\text { an indicator variable equal to } 1 \text { if a date } \\
\text { for a municipality using FAO GAEZ da } \\
\text { to } 1 \text { if the festival for a municipality oce } \\
\text { Fixed Effects are interaction terms betwe } \\
{ }^{* *} p<0.05,{ }^{* * *} p<0.01 \text {. }\end{array}$ & $\begin{array}{l}\text { y-month le } \\
\text { ed at the m } \\
\text { ated using } \\
\text { fficients are } \\
\text { a date falls } \\
\text { al maize har } \\
\text { ariable equ } \\
\text { inicipality u } \\
\text { s within } 0 \mathrm{t} \\
\text { Calendar } \\
\mathrm{s} \text { in a given } \\
\text { calendar we }\end{array}$ & $\begin{array}{l}\text { for munici } \\
\text { cipality lev } \\
00 \mathrm{~km} \mathrm{cu} \\
\text { dltiplied b } \\
\text { in } 0 \text { to } 30 \\
\text { t date for a } \\
01 \text { if a dat } \\
\text { g FAO GA } \\
\text { days after } \\
\text { Fixed Effec } \\
\text { lay period } \\
\text { and Mexic }\end{array}$ & $\begin{array}{l}\text { ties in Mex } \\
\text { re presente } \\
\text { f window } \\
0 \text {. Maize Pl } \\
\text { s prior to th } \\
\text { micipality u } \\
\text { lls within } 0 \\
\text { data. Maize } \\
\text { optimal m } \\
\text { re indicato } \\
\text { fixed effect } \\
\text { tate fixed e }\end{array}$ & $\begin{array}{l}\text { for which we } \\
\text { n parentheses } \\
\text { presented in } \\
\text { ing or Harvest } \\
\text { ptimal maize } \\
\text { g FAO GAEZ } \\
30 \text { days prior } \\
\text { rvest Month is } \\
\text { harvest date } \\
\text { ariables equal } \\
\text { Week by State } \\
\text { ts. }{ }^{*} p<0.10 \text {, }\end{array}$ \\
\hline
\end{tabular}


Table D2: Municipality Characteristics and Coinciding Festivals

\begin{tabular}{|c|c|c|c|c|c|c|c|c|c|}
\hline & \multicolumn{3}{|c|}{$\begin{array}{l}\text { Non-Coinciding } \\
\text { Festival }\end{array}$} & \multicolumn{3}{|c|}{$\begin{array}{l}\text { Coinciding } \\
\text { Festival }\end{array}$} & \multicolumn{3}{|c|}{$\begin{array}{l}\text { Regression Estimates: } \\
\text { Coinciding Festival }\end{array}$} \\
\hline & $\begin{array}{l}\text { Obs. } \\
(1)\end{array}$ & $\begin{array}{c}\text { Mean } \\
(2)\end{array}$ & $\begin{array}{l}\text { SE } \\
(3)\end{array}$ & $\begin{array}{l}\text { Obs. } \\
(4)\end{array}$ & $\begin{array}{c}\text { Mean } \\
(5)\end{array}$ & $\begin{array}{l}\text { SE } \\
(6)\end{array}$ & $\begin{array}{l}\text { Coef. } \\
(7)\end{array}$ & $\begin{array}{c}\text { Robust SE } \\
\text { (8) }\end{array}$ & $\begin{array}{c}\text { Conley SE } \\
\text { (9) }\end{array}$ \\
\hline \multicolumn{10}{|l|}{ Geographic Characteristics: } \\
\hline Precipitation & 1385 & 95.43 & $(1.23)$ & 184 & 98.06 & $(3.66)$ & -2.59 & $(3.53)$ & [3.14] \\
\hline Temperature & 1385 & 19.07 & $(0.11)$ & 184 & 19.67 & $(0.27)$ & -0.09 & $(0.18)$ & {$[0.18]$} \\
\hline Land Suitability & 1385 & 86.40 & $(0.34)$ & 184 & 84.48 & $(1.28)$ & -0.97 & $(0.96)$ & [1.01] \\
\hline Maize Suitability & 1385 & 34.10 & $(0.58)$ & 184 & 34.59 & $(1.64)$ & 2.79 & $(1.55)^{*}$ & {$[1.45]^{*}$} \\
\hline Area & 1385 & 328.32 & (13.35) & 184 & 341.79 & $(40.68)$ & -3.38 & $(36.68)$ & {$[36.38]$} \\
\hline Longitude & 1385 & -98.28 & $(0.05)$ & 184 & -98.19 & $(0.15)$ & -0.06 & $(0.06)$ & {$[0.06]$} \\
\hline Latitude & 1385 & 18.64 & $(0.04)$ & 184 & 18.78 & $(0.13)$ & 0.06 & $(0.06)$ & {$[0.05]$} \\
\hline Log(Dist. to Mexico City) & 1385 & 5.45 & $(0.02)$ & 184 & 5.54 & $(0.04)$ & -0.02 & $(0.02)$ & {$[0.02]$} \\
\hline Slope & 1385 & 10.41 & $(0.17)$ & 184 & 9.58 & $(0.47)$ & -0.53 & $(0.47)$ & {$[0.45]$} \\
\hline Elevation & 1385 & 1569 & $(21.00)$ & 184 & 1459.18 & $(57.58)$ & 35.69 & $(36.55)$ & {$[34.71]$} \\
\hline \multicolumn{10}{|l|}{ Colonial Characteristics: } \\
\hline Has Colonial Characteristics (\%) & 1385 & 86.28 & $(0.92)$ & 184 & 82.61 & $(2.80)$ & 0.18 & $(2.92)$ & {$[2.78]$} \\
\hline Drought in $1545(\%)$ & 1195 & 99.67 & $(0.17)$ & 152 & 98.03 & $(1.13)$ & -1.54 & $(0.91)^{*}$ & [1.04] \\
\hline Log(Pop. Density in 1570) & 1195 & 0.53 & $(0.03)$ & 152 & 0.40 & $(0.08)$ & 0.04 & $(0.06)$ & {$[0.04]$} \\
\hline $\begin{array}{l}\text { Notes: Observations are municipalities in } \\
\text { using a } 100 \mathrm{~km} \text { cut-off window are prese } \\
0-30 \text { days prior to the optimal maize plan } \\
\text { displayed for regression estimates is the } \\
\text { festival week fixed effects. Robust stand } \\
\text { characteristics for all observations in ou } \\
\text { colonial characteristics. }{ }^{*} p<0.10,{ }^{* *} p<\end{array}$ & $\begin{array}{l}\text { New } S p \\
\text { in bracl }\end{array}$ & $\begin{array}{l}\text { gion of } \\
\text { Coincidi } \\
\text { days af }\end{array}$ & $\begin{array}{l}\text { o. Robu } \\
\text { tival is a }\end{array}$ & dard & $\begin{array}{l}\text { are prese } \\
\text { le equal } \\
\text { late for a }\end{array}$ & $\begin{array}{l}\text { in paren } \\
\text { the sain } \\
\text { cipality }\end{array}$ & $\begin{array}{l}S \text { and } C \\
\text { festiva }\end{array}$ & $\begin{array}{l}\text { (1999) stand } \\
\text { municipality } \\
\text { data, and } 0 \mathrm{c} \\
\text { harvest-mor } \\
\text { Note that we } \\
1 \text { if a munici }\end{array}$ & $\begin{array}{l}\text { rrors calculat } \\
\text { urs either with } \\
\text { wise. The val } \\
\text { ixed effects, a } \\
\text { ot have colon } \\
y \text { is not missi }\end{array}$ \\
\hline
\end{tabular}

Table D3: Municipality Characteristics and Coinciding Festivals: All of Mexico

\begin{tabular}{|c|c|c|c|c|c|c|c|c|c|}
\hline & \multicolumn{3}{|c|}{$\begin{array}{l}\text { Non-Coinciding } \\
\text { Festival }\end{array}$} & \multicolumn{3}{|c|}{$\begin{array}{l}\text { Coinciding } \\
\text { Festival }\end{array}$} & \multicolumn{3}{|c|}{$\begin{array}{l}\text { Regression Estimates: } \\
\text { Coinciding Festival }\end{array}$} \\
\hline & $\begin{array}{l}\text { Obs. } \\
(1)\end{array}$ & $\begin{array}{c}\text { Mean } \\
(2)\end{array}$ & $\begin{array}{l}\text { SE } \\
(3)\end{array}$ & $\begin{array}{l}\text { Obs. } \\
(4)\end{array}$ & $\begin{array}{c}\text { Mean } \\
(5)\end{array}$ & $\begin{array}{l}\text { SE } \\
(6)\end{array}$ & $\begin{array}{c}\text { Coef. } \\
\text { (7) }\end{array}$ & $\begin{array}{c}\text { Robust SE } \\
\text { (8) }\end{array}$ & $\begin{array}{c}\text { Conley SE } \\
\text { (9) }\end{array}$ \\
\hline \multicolumn{10}{|l|}{ Geographic Characteristics: } \\
\hline Precipitation & 1746 & 89.55 & $(1.08)$ & 273 & 85.85 & $(2.87)$ & -3.70 & $(2.55)$ & {$[2.30]$} \\
\hline Temperature & 1746 & 19.58 & $(0.10)$ & 273 & 20.23 & $(0.22)$ & -0.17 & $(0.17)$ & {$[0.16]$} \\
\hline Land Suitability & 1746 & 81.04 & $(0.55)$ & 273 & 75.25 & $(1.74)$ & -0.27 & $(0.90)$ & {$[0.85]$} \\
\hline Maize Suitability & 1746 & 32.24 & $(0.50)$ & 273 & 30.99 & $(1.24)$ & 1.75 & $(1.11)$ & [1.10] \\
\hline Area & 1746 & 620.73 & $(31.81)$ & 273 & 973.90 & (114.66) & 90.65 & $(90.08)$ & {$[87.92]$} \\
\hline Longitude & 1746 & -98.58 & $(0.09)$ & 273 & -99.22 & $(0.29)$ & -0.05 & $(0.06)$ & {$[0.05]$} \\
\hline Latitude & 1746 & 19.60 & $(0.06)$ & 273 & 20.59 & $(0.22)$ & 0.10 & $(0.05)^{*}$ & {$[0.05]^{* *}$} \\
\hline Log(Dist. to Mexico City) & 1746 & 5.71 & $(0.02)$ & 273 & 5.96 & $(0.05)$ & -0.02 & $(0.02)$ & {$[0.02]$} \\
\hline Slope & 1746 & 9.33 & $(0.16)$ & 273 & 8.28 & $(0.38)$ & -0.58 & $(0.35)$ & {$[0.35]^{*}$} \\
\hline Elevation & 1746 & 1429.96 & $(20.10)$ & 273 & 1258.70 & $(50.72)$ & 45.66 & $(33.07)$ & {$[30.75]$} \\
\hline \multicolumn{10}{|l|}{ Colonial Characteristics: } \\
\hline Has Colonial Characteristics (\%) & 1746 & 78.47 & $(0.98)$ & 273 & 73.26 & $(2.68)$ & -0.45 & $(2.15)$ & {$[2.14]$} \\
\hline Drought in $1545(\%)$ & 1370 & 98.18 & $(0.36)$ & 200 & 97.50 & $(1.11)$ & 0.40 & $(1.16)$ & [1.28] \\
\hline Log(Pop. Density in 1570) & 1370 & 0.32 & $(0.03)$ & 200 & 0.02 & $(0.08)$ & 0.04 & $(0.05)$ & {$[0.04]$} \\
\hline
\end{tabular}


Table D4: Development Outcomes and Planting- and Harvest-Coinciding Festivals

\begin{tabular}{|c|c|c|c|c|c|}
\hline & \multicolumn{5}{|c|}{$\begin{array}{l}\text { Dependent Variable: } \\
\text { Panel A: Log HH Income }\end{array}$} \\
\hline & $(1)$ & $(2)$ & (3) & $(4)$ & (5) \\
\hline Festival: 0-30 Days Prior to Maize Planting & $\begin{array}{c}-0.368^{* *} \\
(0.149) \\
{[0.161]}\end{array}$ & $\begin{array}{r}-0.152 \\
(0.126) \\
{[0.117]}\end{array}$ & $\begin{array}{c}-0.268^{* *} \\
(0.112) \\
{[0.130]}\end{array}$ & $\begin{array}{c}-0.291^{* * *} \\
(0.110) \\
{[0.129]}\end{array}$ & $\begin{array}{c}-0.268^{* *} \\
(0.128) \\
{[0.136]}\end{array}$ \\
\hline Festival: 0-30 Days After Maize Harvest & $\begin{array}{r}-0.217^{*} \\
(0.125) \\
{[0.135]}\end{array}$ & $\begin{array}{c}-0.237^{* *} \\
(0.097) \\
{[0.098]}\end{array}$ & $\begin{array}{c}-0.241^{* * *} \\
(0.086) \\
{[0.088]}\end{array}$ & $\begin{array}{c}-0.233^{* * *} \\
(0.086) \\
{[0.087]}\end{array}$ & $\begin{array}{c}-0.171^{*} \\
(0.095) \\
{[0.087]}\end{array}$ \\
\hline $\begin{array}{l}\text { State Fixed Effects } \\
\text { Geography Controls } \\
\text { Colonial Controls } \\
\text { Planting-Month Fixed Effects } \\
\text { Harvest-Month Fixed Effects } \\
\text { Festival-Week Fixed Effects }\end{array}$ & $\begin{array}{l}\mathrm{N} \\
\mathrm{N} \\
\mathrm{N} \\
\mathrm{N} \\
\mathrm{N} \\
\mathrm{N}\end{array}$ & $\begin{array}{l}\mathrm{Y} \\
\mathrm{N} \\
\mathrm{N} \\
\mathrm{N} \\
\mathrm{N} \\
\mathrm{N}\end{array}$ & $\begin{array}{l}\mathrm{Y} \\
\mathrm{Y} \\
\mathrm{N} \\
\mathrm{N} \\
\mathrm{N} \\
\mathrm{N}\end{array}$ & $\begin{array}{l}\mathrm{Y} \\
\mathrm{Y} \\
\mathrm{Y} \\
\mathrm{N} \\
\mathrm{N} \\
\mathrm{N}\end{array}$ & $\begin{array}{l}Y \\
Y \\
Y \\
Y \\
Y \\
Y\end{array}$ \\
\hline $\begin{array}{l}\text { Observations } \\
\text { Adjusted R2 } \\
\text { Mean Dep. Var. } \\
\text { SD Dep. Var. } \\
\text { P-Value: Difference }\end{array}$ & $\begin{array}{l}1,593 \\
0.004 \\
3.234 \\
1.330 \\
0.422\end{array}$ & $\begin{array}{l}1,593 \\
0.347 \\
3.234 \\
1.330 \\
0.577\end{array}$ & $\begin{array}{l}1,593 \\
0.537 \\
3.234 \\
1.330 \\
0.844\end{array}$ & $\begin{array}{l}1,593 \\
0.543 \\
3.234 \\
1.330 \\
0.666\end{array}$ & $\begin{array}{l}1,593 \\
0.566 \\
3.234 \\
1.330 \\
0.542\end{array}$ \\
\hline \multirow{2}{*}{ P-Value: Difference } & \multicolumn{5}{|c|}{ Dependent Variable: } \\
\hline & (1) & (2) & (3) & (4) & $(5)$ \\
\hline Festival: 0-30 Days Prior to Maize Planting & $\begin{array}{c}-0.775^{*} \\
(0.459) \\
{[0.502]}\end{array}$ & $\begin{array}{c}-0.035 \\
(0.391) \\
{[0.356]}\end{array}$ & $\begin{array}{c}-0.361 \\
(0.356) \\
{[0.369]}\end{array}$ & $\begin{array}{c}-0.443 \\
(0.353) \\
{[0.368]}\end{array}$ & $\begin{array}{c}-0.496 \\
(0.388) \\
{[0.374]}\end{array}$ \\
\hline Festival: 0-30 Days After Maize Harvest & $\begin{array}{r}-0.645^{*} \\
(0.376) \\
{[0.419]}\end{array}$ & $\begin{array}{c}-0.663^{* *} \\
(0.284) \\
{[0.306]}\end{array}$ & $\begin{array}{c}-0.737^{* * *} \\
(0.243) \\
{[0.256]}\end{array}$ & $\begin{array}{c}-0.718^{* * *} \\
(0.244) \\
{[0.259]}\end{array}$ & $\begin{array}{c}-0.560^{* *} \\
(0.267) \\
{[0.231]}\end{array}$ \\
\hline
\end{tabular}

State Fixed Effects

Geography Controls

Colonial Controls

Planting-Month Fixed Effects

Harvest-Month Fixed Effects

Festival-Week Fixed Effects

\begin{tabular}{lccccc} 
Observations & 1,593 & 1,593 & 1,593 & 1,593 & 1,593 \\
Adjusted R2 & 0.002 & 0.348 & 0.566 & 0.571 & 0.597 \\
Mean Dep. Var. & -0.589 & -0.589 & -0.589 & -0.589 & -0.589 \\
SD Dep. Var. & 4.039 & 4.039 & 4.039 & 4.039 & 4.039 \\
P-Value: Difference & 0.820 & 0.177 & 0.370 & 0.511 & 0.891 \\
\hline
\end{tabular}

Notes: Data is from the 2010 Mexico Population Census. Observations are municipalities in the New Spain region of Mexico. Robust standard errors are presented in parentheses and Conley (1999) standard errors calculated using a $100 \mathrm{~km}$ cut-off window are presented in brackets. Index of Economic Development is the first principal component index for a number of development outcomes in the census for a municipality (see Data Appendix). Festival Coincides with Maize Planting or Harvest is an indicator variable equal to 1 if the saint day festival in a municipality occurs either 0 to 30 days prior to the optimal maize planting date or 0 to 30 days after the optimal maize harvest date for a municipality using FAO GAEZ data. Geography Controls includes mean temperature, mean precipitation, mean land suitability, the surface area, centroid latitude, centroid longitude, mean elevation, mean slope, log distance to Mexico City, and mean maize suitability for the municipality. Colonial Controls includes drought intensity in 1545 and $\log$ population density in 1570 using data from Sellers and Alix-Garcia (2018). For these colonial controls, values for municipalities with missing information are set to zero, and we control for an indicator variable equal to 1 if the municipality is not missing these colonial characteristics. Planting $\mathcal{E}$ Harvest Month Fixed Effects includes fixed effects for the optimal planting-month and harvest-month for 2 \&e for each municipality according to FAO GAEZ data. Festival-Week Fixed Effects are fixed effects for the calendar date of the municipality's saint day festival. ${ }^{*} p<0.10, * *$ $p<0.05,{ }^{* * *} p<0.01$. 
Table D5: Impact of Agriculturally-Coinciding Festivals on Development Outcomes: All of Mexico

\begin{tabular}{|c|c|c|c|c|c|}
\hline & \multicolumn{5}{|c|}{$\begin{array}{l}\text { Dependent Variable: } \\
\text { Panel A: Log HH Income }\end{array}$} \\
\hline & $(1)$ & $(2)$ & (3) & $(4)$ & (5) \\
\hline Festival Coincides with Maize Planting or Harvest & $\begin{array}{c}-0.009 \\
(0.080) \\
{[0.094]}\end{array}$ & $\begin{array}{c}-0.099 \\
(0.063) \\
{[0.065]}\end{array}$ & $\begin{array}{c}-0.138^{* *} \\
(0.056) \\
{[0.064]}\end{array}$ & $\begin{array}{c}-0.140^{* *} \\
(0.056) \\
{[0.063]}\end{array}$ & $\begin{array}{c}-0.110^{*} \\
(0.060) \\
{[0.060]}\end{array}$ \\
\hline State Fixed Effects & $\mathrm{N}$ & $\mathrm{Y}$ & $\mathrm{Y}$ & $\mathrm{Y}$ & $\mathrm{Y}$ \\
\hline Geography Controls & $\mathrm{N}$ & $\mathrm{N}$ & $\mathrm{Y}$ & $\mathrm{Y}$ & $\mathrm{Y}$ \\
\hline Colonial Controls & $\mathrm{N}$ & $\mathrm{N}$ & $\mathrm{N}$ & $\mathrm{Y}$ & $\mathrm{Y}$ \\
\hline Planting-Month Fixed Effects & $\mathrm{N}$ & $\mathrm{N}$ & $\mathrm{N}$ & $\mathrm{N}$ & $\mathrm{Y}$ \\
\hline Harvest-Month Fixed Effects & $\mathrm{N}$ & $\mathrm{N}$ & $\mathrm{N}$ & $\mathrm{N}$ & $\mathrm{Y}$ \\
\hline Festival-Week Fixed Effects & $\mathrm{N}$ & $\mathrm{N}$ & $\mathrm{N}$ & $\mathrm{N}$ & $\mathrm{Y}$ \\
\hline Observations & 2,277 & 2,277 & 2,277 & 2,277 & 2,277 \\
\hline Adjusted R2 & -0.000 & 0.351 & 0.518 & 0.522 & 0.534 \\
\hline Mean Dep. Var. & 3.379 & 3.379 & 3.379 & 3.379 & 3.379 \\
\hline \multirow[t]{4}{*}{ SD Dep. Var. } & 1.316 & 1.316 & 1.316 & 1.316 & 1.316 \\
\hline & \multicolumn{5}{|c|}{ Dependent Variable: } \\
\hline & \multicolumn{5}{|c|}{ Panel B: Index of Economic Development } \\
\hline & $(1)$ & $(2)$ & (3) & $(4)$ & (5) \\
\hline Festival Coincides with Maize Planting or Harvest & $\begin{array}{c}0.103 \\
(0.249) \\
{[0.315]}\end{array}$ & $\begin{array}{c}-0.231 \\
(0.194) \\
{[0.204]}\end{array}$ & $\begin{array}{c}-0.348^{* *} \\
(0.171) \\
{[0.187]}\end{array}$ & $\begin{array}{c}-0.353^{* *} \\
(0.171) \\
{[0.186]}\end{array}$ & $\begin{array}{c}-0.283 \\
(0.181) \\
{[0.167]}\end{array}$ \\
\hline State Fixed Effects & $\mathrm{N}$ & $\mathrm{Y}$ & $\mathrm{Y}$ & $\mathrm{Y}$ & $\mathrm{Y}$ \\
\hline Geography Controls & $\mathrm{N}$ & $\mathrm{N}$ & $\mathrm{Y}$ & $\mathrm{Y}$ & $\mathrm{Y}$ \\
\hline Colonial Controls & $\mathrm{N}$ & $\mathrm{N}$ & $\mathrm{N}$ & $\mathrm{Y}$ & $\mathrm{Y}$ \\
\hline Planting-Month Fixed Effects & $\mathrm{N}$ & $\mathrm{N}$ & $\mathrm{N}$ & $\mathrm{N}$ & $\mathrm{Y}$ \\
\hline Harvest-Month Fixed Effects & $\mathrm{N}$ & $\mathrm{N}$ & $\mathrm{N}$ & $\mathrm{N}$ & Y \\
\hline Festival-Week Fixed Effects & $\mathrm{N}$ & $\mathrm{N}$ & $\mathrm{N}$ & $\mathrm{N}$ & Y \\
\hline Observations & 2,277 & 2,277 & 2,277 & 2,277 & 2,277 \\
\hline Adjusted R2 & -0.000 & 0.379 & 0.557 & 0.560 & 0.573 \\
\hline Mean Dep. Var. & -0.084 & -0.084 & -0.084 & -0.084 & -0.084 \\
\hline SD Dep. Var. & 4.052 & 4.052 & 4.052 & 4.052 & 4.052 \\
\hline \multicolumn{6}{|c|}{$\begin{array}{l}\text { Notes: Data is from the } 2010 \text { Mexico Population Census. Observations are municipalities in Mexico. Robust standard errors } \\
\text { are presented in parentheses and Conley (1999) standard errors calculated using a } 100 \mathrm{~km} \text { cut-off window are presented in } \\
\text { brackets. Index of Economic Development is the first principal component index for a number of development outcomes in } \\
\text { the census for a municipality (see Data Appendix). Festival Coincides with Maize Planting or Harvest is an indicator variable } \\
\text { equal to } 1 \text { if the saint day festival in a municipality occurs either } 0 \text { to } 30 \text { days prior to the optimal maize planting date or } \\
0 \text { to } 30 \text { days after the optimal maize harvest date for a municipality using FAO GAEZ data. Geography Controls includes } \\
\text { mean temperature, mean precipitation, mean land suitability, the surface area, centroid latitude, centroid longitude, mean } \\
\text { elevation, mean slope, log distance to Mexico City, and mean maize suitability for the municipality. Colonial Controls } \\
\text { includes drought intensity in } 1545 \text { and log population density in } 1570 \text { using data from Sellers and Alix-Garcia (2018). For } \\
\text { these colonial controls, values for municipalities with missing information are set to zero, and we control for an indicator } \\
\text { variable equal to } 1 \text { if the municipality is not missing these colonial characteristics. Planting \& Harvest Month Fixed Effects } \\
\text { includes fixed effects for the optimal planting-month and harvest-month for maize for each municipality according to FAO } \\
\text { GAEZ data. Festival-Week Fixed Effects are fixed effects for the calendar date of the municipality's saint day festival. * } \\
p<0.10, * * p<0.05, * * p<0.01 \text {. }\end{array}$} \\
\hline
\end{tabular}


Table D6: Municipality Characteristics and Undetermined Festival Date

\begin{tabular}{|c|c|c|c|c|c|c|c|c|c|}
\hline & \multicolumn{3}{|c|}{$\begin{array}{l}\text { Festival Date } \\
\text { Determined }\end{array}$} & \multicolumn{3}{|c|}{$\begin{array}{l}\text { Festival Date } \\
\text { Undetermined }\end{array}$} & \multicolumn{3}{|c|}{$\begin{array}{l}\text { Regression Estimates: } \\
\text { Festival Date Undetermined }\end{array}$} \\
\hline & $\begin{array}{l}\text { Obs. } \\
(1)\end{array}$ & $\begin{array}{l}\text { Mean } \\
(2)\end{array}$ & $\begin{array}{l}\text { SE } \\
\text { (3) }\end{array}$ & $\begin{array}{l}\text { Obs. } \\
(4)\end{array}$ & $\begin{array}{c}\text { Mean } \\
(5)\end{array}$ & $\begin{array}{l}\text { SE } \\
(6)\end{array}$ & $\begin{array}{l}\text { Coef. } \\
(7)\end{array}$ & $\begin{array}{c}\text { Robust SE } \\
\text { (8) }\end{array}$ & $\begin{array}{c}\text { Conley SE } \\
\text { (9) }\end{array}$ \\
\hline \multicolumn{10}{|l|}{ Geographic Characteristics: } \\
\hline Precipitation & 1569 & 95.74 & $(1.17)$ & 46 & 101.68 & (7.93) & 1.98 & $(6.81)$ & [5.45] \\
\hline Temperature & 1569 & 19.14 & $(0.10)$ & 46 & 20.10 & $(0.61)$ & 0.76 & $(0.49)$ & {$[0.53]$} \\
\hline Land Suitability & 1569 & 86.17 & $(0.34)$ & 46 & 80.83 & (2.53) & -4.84 & $(2.10)^{* *}$ & {$[1.80]^{* * *}$} \\
\hline Maize Suitability & 1569 & 34.16 & $(0.55)$ & 46 & 36.85 & $(2.96)$ & 2.34 & $(2.97)$ & {$[3.02]$} \\
\hline Area & 1569 & 329.90 & $(12.71)$ & 46 & 416.61 & $(81.26)$ & 52.42 & $(80.18)$ & [80.17] \\
\hline Longitude & 1569 & -98.27 & $(0.05)$ & 46 & -98.10 & $(0.28)$ & 0.18 & $(0.11)$ & {$[0.09]^{*}$} \\
\hline Latitude & 1569 & 18.66 & $(0.04)$ & 46 & 19.14 & $(0.23)$ & -0.11 & $(0.12)$ & {$[0.11]$} \\
\hline Log(Dist. to Mexico City) & 1569 & 5.46 & $(0.02)$ & 46 & 5.41 & $(0.10)$ & 0.07 & $(0.05)$ & {$[0.03]^{* *}$} \\
\hline Slope & 1569 & 10.32 & $(0.16)$ & 46 & 8.71 & $(1.00)$ & -0.82 & $(0.97)$ & {$[1.06]$} \\
\hline Elevation & 1569 & 1556.12 & (19.74) & 46 & 1314.65 & (134.19) & -137.09 & (93.95) & [99.79] \\
\hline \multicolumn{10}{|l|}{ Colonial Characteristics: } \\
\hline Has Colonial Characteristics (\%) & 1569 & 85.85 & $(0.88)$ & 46 & 82.61 & $(5.65)$ & -0.94 & $(4.83)$ & [4.61] \\
\hline Drought in $1545(\%)$ & 1347 & 99.48 & $(0.20)$ & 38 & 100 & $(0.00)$ & 0.68 & $(0.69)$ & [0.55] \\
\hline Log(Pop. Density in 1570) & 1347 & 0.52 & $(0.03)$ & 38 & 0.53 & $(0.21)$ & -0.12 & $(0.12)$ & {$[0.10]$} \\
\hline
\end{tabular}

Table D7: Municipality Characteristics and "Local" Patron Saints

\begin{tabular}{|c|c|c|c|c|c|c|c|c|c|}
\hline & \multicolumn{3}{|c|}{$\begin{array}{c}\text { Official } \\
\text { Patron Saint }\end{array}$} & \multicolumn{3}{|c|}{$\begin{array}{c}\text { Local } \\
\text { Patron Saint }\end{array}$} & \multicolumn{3}{|c|}{$\begin{array}{l}\text { Regression Estimates: } \\
\text { Local Patron Saint }\end{array}$} \\
\hline & $\begin{array}{l}\text { Obs. } \\
(1)\end{array}$ & $\begin{array}{c}\text { Mean } \\
(2)\end{array}$ & $\begin{array}{l}\text { SE } \\
(3)\end{array}$ & $\begin{array}{l}\text { Obs. } \\
(4)\end{array}$ & $\begin{array}{c}\text { Mean } \\
(5)\end{array}$ & $\begin{array}{l}\text { SE } \\
(6)\end{array}$ & $\begin{array}{c}\text { Coef. } \\
\text { (7) }\end{array}$ & $\begin{array}{c}\text { Robust SE } \\
\text { (8) }\end{array}$ & $\begin{array}{c}\text { Conley SE } \\
\text { (9) }\end{array}$ \\
\hline \multicolumn{10}{|l|}{ Geographic Characteristics: } \\
\hline Precipitation & 1569 & 95.74 & $(1.17)$ & 30 & 79.19 & $(5.86)$ & -7.18 & $(5.93)$ & {$[5.23]$} \\
\hline Temperature & 1569 & 19.14 & $(0.10)$ & 30 & 18.62 & $(0.72)$ & -0.01 & $(0.40)$ & {$[0.34]$} \\
\hline Land Suitability & 1569 & 86.17 & $(0.34)$ & 30 & 86.18 & $(3.28)$ & -0.58 & $(1.76)$ & {$[1.71]$} \\
\hline Maize Suitability & 1569 & 34.16 & $(0.55)$ & 30 & 44.66 & $(3.36)$ & 3.13 & $(2.60)$ & {$[2.78]$} \\
\hline Area & 1569 & 329.90 & $(12.71)$ & 30 & 388.11 & $(79.26)$ & -42.18 & $(54.82)$ & [57.86] \\
\hline Longitude & 1569 & -98.27 & $(0.05)$ & 30 & -99.82 & $(0.39)$ & -0.18 & $(0.11)^{*}$ & {$[0.10]^{*}$} \\
\hline Latitude & 1569 & 18.66 & $(0.04)$ & 30 & 19.74 & $(0.19)$ & 0.13 & $(0.11)$ & {$[0.11]$} \\
\hline Log(Dist. to Mexico City) & 1569 & 5.46 & $(0.02)$ & 30 & 5.24 & $(0.13)$ & 0.08 & $(0.05)$ & {$[0.05]$} \\
\hline Slope & 1569 & 10.32 & $(0.16)$ & 30 & 6.94 & $(0.64)$ & -1.07 & $(0.69)$ & {$[0.71]$} \\
\hline Elevation & 1569 & 1556.12 & $(19.74)$ & 30 & 1726.58 & $(138.85)$ & 58.33 & $(79.37)$ & [69.05] \\
\hline \multicolumn{10}{|l|}{ Colonial Characteristics: } \\
\hline Has Colonial Characteristics (\%) & 1569 & 85.85 & $(0.88)$ & 30 & 93.33 & $(4.63)$ & 4.39 & $(4.55)$ & {$[4.51]$} \\
\hline Drought in $1545(\%)$ & 1347 & 99.48 & $(0.20)$ & 28 & 100 & $(0.00)$ & 1.02 & $(0.84)$ & [0.87] \\
\hline Log(Pop. Density in 1570) & 1347 & 0.52 & $(0.03)$ & 28 & 0.56 & $(0.23)$ & -0.08 & $(0.12)$ & [0.09] \\
\hline
\end{tabular}


Table D8: Robustness to Missing Festival Dates: Development Outcomes (Assuming All Municipalities with Missing Festival Dates Have Coinciding Festivals)

\begin{tabular}{|c|c|c|c|c|c|}
\hline & \multicolumn{5}{|c|}{$\begin{array}{l}\text { Dependent Variable: } \\
\text { Panel A: Log HH Income }\end{array}$} \\
\hline & $(1)$ & (2) & (3) & (4) & (5) \\
\hline Festival Coincides with Maize Planting or Harvest & $\begin{array}{c}-0.191^{* *} \\
(0.090) \\
{[0.094]}\end{array}$ & $\begin{array}{c}-0.173^{* *} \\
(0.073) \\
{[0.073]}\end{array}$ & $\begin{array}{c}-0.220^{* * *} \\
(0.063) \\
{[0.071]}\end{array}$ & $\begin{array}{c}-0.219^{* * *} \\
(0.063) \\
{[0.069]}\end{array}$ & $\begin{array}{c}-0.201^{* * *} \\
(0.069) \\
{[0.068]}\end{array}$ \\
\hline $\begin{array}{l}\text { State Fixed Effects } \\
\text { Geography Controls } \\
\text { Colonial Controls } \\
\text { Planting-Month Fixed Effects } \\
\text { Harvest-Month Fixed Effects } \\
\text { Festival-Week Fixed Effects }\end{array}$ & $\begin{array}{l}\mathrm{N} \\
\mathrm{N} \\
\mathrm{N} \\
\mathrm{N} \\
\mathrm{N} \\
\mathrm{N}\end{array}$ & $\begin{array}{l}\mathrm{Y} \\
\mathrm{N} \\
\mathrm{N} \\
\mathrm{N} \\
\mathrm{N} \\
\mathrm{N}\end{array}$ & $\begin{array}{l}\mathrm{Y} \\
\mathrm{Y} \\
\mathrm{N} \\
\mathrm{N} \\
\mathrm{N} \\
\mathrm{N}\end{array}$ & $\begin{array}{l}\mathrm{Y} \\
\mathrm{Y} \\
\mathrm{Y} \\
\mathrm{N} \\
\mathrm{N} \\
\mathrm{N}\end{array}$ & $\begin{array}{l}\mathrm{Y} \\
\mathrm{Y} \\
\mathrm{Y} \\
\mathrm{Y} \\
\mathrm{Y} \\
\mathrm{Y}\end{array}$ \\
\hline $\begin{array}{l}\text { Observations } \\
\text { Adjusted R2 } \\
\text { Mean Dep. Var. } \\
\text { SD Dep. Var. }\end{array}$ & $\begin{array}{l}1,639 \\
0.002 \\
3.239 \\
1.328\end{array}$ & $\begin{array}{l}1,639 \\
0.345 \\
3.239 \\
1.328\end{array}$ & $\begin{array}{l}1,639 \\
0.538 \\
3.239 \\
1.328\end{array}$ & $\begin{array}{l}1,639 \\
0.543 \\
3.239 \\
1.328\end{array}$ & $\begin{array}{l}1,632 \\
0.562 \\
3.238 \\
1.329\end{array}$ \\
\hline \multirow{2}{*}{ SD Dep. Var. } & \multicolumn{5}{|c|}{$\begin{array}{c}\text { Dependent Variable: } \\
\text { Panel B: Index of Economic Development }\end{array}$} \\
\hline & $(1)$ & $(2)$ & (3) & $(4)$ & $(5)$ \\
\hline Festival Coincides with Maize Planting or Harvest & $\begin{array}{r}-0.478^{*} \\
(0.277) \\
{[0.298]}\end{array}$ & $\begin{array}{c}-0.328 \\
(0.227) \\
{[0.236]}\end{array}$ & $\begin{array}{c}-0.485^{* *} \\
(0.194) \\
{[0.209]}\end{array}$ & $\begin{array}{c}-0.492^{* *} \\
(0.194) \\
{[0.206]}\end{array}$ & $\begin{array}{c}-0.525^{* *} \\
(0.207) \\
{[0.198]}\end{array}$ \\
\hline $\begin{array}{l}\text { State Fixed Effects } \\
\text { Geography Controls } \\
\text { Colonial Controls } \\
\text { Planting-Month Fixed Effects } \\
\text { Harvest-Month Fixed Effects } \\
\text { Festival-Week Fixed Effects }\end{array}$ & $\begin{array}{l}\mathrm{N} \\
\mathrm{N} \\
\mathrm{N} \\
\mathrm{N} \\
\mathrm{N} \\
\mathrm{N}\end{array}$ & $\begin{array}{l}\mathrm{Y} \\
\mathrm{N} \\
\mathrm{N} \\
\mathrm{N} \\
\mathrm{N} \\
\mathrm{N}\end{array}$ & $\begin{array}{l}\mathrm{Y} \\
\mathrm{Y} \\
\mathrm{N} \\
\mathrm{N} \\
\mathrm{N} \\
\mathrm{N}\end{array}$ & $\begin{array}{l}\mathrm{Y} \\
\mathrm{Y} \\
\mathrm{Y} \\
\mathrm{N} \\
\mathrm{N} \\
\mathrm{N}\end{array}$ & $\begin{array}{l}\mathrm{Y} \\
\mathrm{Y} \\
\mathrm{Y} \\
\mathrm{Y} \\
\mathrm{Y} \\
\mathrm{Y}\end{array}$ \\
\hline $\begin{array}{l}\text { Observations } \\
\text { Adjusted R2 } \\
\text { Mean Dep. Var. } \\
\text { SD Dep. Var. }\end{array}$ & $\begin{array}{c}1,639 \\
0.001 \\
-0.576 \\
4.039\end{array}$ & $\begin{array}{c}1,639 \\
0.344 \\
-0.576 \\
4.039\end{array}$ & $\begin{array}{c}1,639 \\
0.563 \\
-0.576 \\
4.039\end{array}$ & $\begin{array}{c}1,639 \\
0.568 \\
-0.576 \\
4.039\end{array}$ & $\begin{array}{c}1,632 \\
0.588 \\
-0.574 \\
4.047\end{array}$ \\
\hline
\end{tabular}

Notes: Regressions in this table are identical to those in Table 2, except that municipalities with missing festival dates (previously not included in sample) are now included in the sample, and we assume that their festivals all coincide with planting or harvest (for these observations, festival week is randomly chosen for the inclusion of Festival-Week Fixed Effects in column 5). Data is from the 2010 Mexico Population Census. Observations are municipalities in the New Spain region of Mexico. Robust standard errors are presented in parentheses and Conley (1999) standard errors calculated using a 100 $\mathrm{km}$ cut-off window are presented in brackets. Index of Economic Development is the first principal component index for a number of development outcomes in the census for a municipality (see Data Appendix). Festival Coincides with Maize Planting or Harvest is an indicator variable equal to 1 if the saint day festival in a municipality occurs either 0 to 30 days prior to the optimal maize planting date or 0 to 30 days after the optimal maize harvest date for a municipality using FAO GAEZ data. For this table, we assume all undetermined festival dates are coinciding festivals. Geography Controls includes mean temperature, mean precipitation, mean land suitability, the surface area, centroid latitude, centroid longitude, mean elevation, mean slope, log distance to Mexico City, and mean maize suitability for the municipality. Colonial Controls includes drought intensity in 1545 and $\log$ population density in 1570 using data from Sellers and Alix-Garcia (2018). For these colonial controls, values for municipalities with missing information are set to zero, and we control for an indicator variable equal to 1 if the municipality is not missing these colonial characteristics. Planting $\mathcal{E}$ Harvest Month Fixed Effects includes fixed effects for the optimal planting-month and harvest-month for maize for each municipality according to FAO GAEZ data. Festival-Week Fixed Effects are fixed effects for the calendar date of the municipality's saint day festival. * $p<0.10,^{* *} p<0.05,{ }^{* * *} p<0.01$. 
Table D9: Robustness to Missing Festival Dates: Development Outcomes (Assuming No Municipalities with Missing Festival Dates Have Coinciding Festivals)

\begin{tabular}{|c|c|c|c|c|c|}
\hline & \multicolumn{5}{|c|}{$\begin{array}{l}\text { Dependent Variable: } \\
\text { Panel A: Log HH Income }\end{array}$} \\
\hline & (1) & (2) & (3) & (4) & (5) \\
\hline Festival Coincides with Maize Planting or Harvest & $\begin{array}{c}-0.280^{* * *} \\
(0.099) \\
{[0.107]}\end{array}$ & $\begin{array}{c}-0.205^{* * *} \\
(0.079) \\
{[0.079]}\end{array}$ & $\begin{array}{c}-0.249^{* * *} \\
(0.070) \\
{[0.081]}\end{array}$ & $\begin{array}{c}-0.254^{* * *} \\
(0.070) \\
{[0.079]}\end{array}$ & $\begin{array}{c}-0.228^{* * *} \\
(0.075) \\
{[0.078]}\end{array}$ \\
\hline $\begin{array}{l}\text { State Fixed Effects } \\
\text { Geography Controls } \\
\text { Colonial Controls } \\
\text { Planting-Month Fixed Effects } \\
\text { Harvest-Month Fixed Effects } \\
\text { Festival-Week Fixed Effects }\end{array}$ & $\begin{array}{l}\mathrm{N} \\
\mathrm{N} \\
\mathrm{N} \\
\mathrm{N} \\
\mathrm{N} \\
\mathrm{N}\end{array}$ & $\begin{array}{l}\mathrm{Y} \\
\mathrm{N} \\
\mathrm{N} \\
\mathrm{N} \\
\mathrm{N} \\
\mathrm{N}\end{array}$ & $\begin{array}{l}\mathrm{Y} \\
\mathrm{Y} \\
\mathrm{N} \\
\mathrm{N} \\
\mathrm{N} \\
\mathrm{N}\end{array}$ & $\begin{array}{l}\mathrm{Y} \\
\mathrm{Y} \\
\mathrm{Y} \\
\mathrm{N} \\
\mathrm{N} \\
\mathrm{N}\end{array}$ & $\begin{array}{l}\mathrm{Y} \\
\mathrm{Y} \\
\mathrm{Y} \\
\mathrm{Y} \\
\mathrm{Y} \\
\mathrm{Y}\end{array}$ \\
\hline $\begin{array}{l}\text { Observations } \\
\text { Adjusted R2 } \\
\text { Mean Dep. Var. } \\
\text { SD Dep. Var. }\end{array}$ & $\begin{array}{l}1,639 \\
0.004 \\
3.239 \\
1.328\end{array}$ & $\begin{array}{l}1,639 \\
0.345 \\
3.239 \\
1.328\end{array}$ & $\begin{array}{l}1,639 \\
0.538 \\
3.239 \\
1.328\end{array}$ & $\begin{array}{l}1,639 \\
0.543 \\
3.239 \\
1.328\end{array}$ & $\begin{array}{l}1,631 \\
0.561 \\
3.237 \\
1.329\end{array}$ \\
\hline \multirow{2}{*}{ SD Dep. Var. } & \multicolumn{5}{|c|}{$\begin{array}{c}\text { Dependent Variable: } \\
\text { Panel B: Index of Economic Development }\end{array}$} \\
\hline & $(1)$ & (2) & (3) & $(4)$ & $(5)$ \\
\hline Festival Coincides with Maize Planting or Harvest & $\begin{array}{c}-0.708^{* *} \\
(0.300) \\
{[0.342]}\end{array}$ & $\begin{array}{c}-0.428^{*} \\
(0.239) \\
{[0.249]}\end{array}$ & $\begin{array}{c}-0.592^{* * *} \\
(0.208) \\
{[0.224]}\end{array}$ & $\begin{array}{c}-0.613^{* * *} \\
(0.207) \\
{[0.218]}\end{array}$ & $\begin{array}{c}-0.617^{* * *} \\
(0.226) \\
{[0.210]}\end{array}$ \\
\hline $\begin{array}{l}\text { State Fixed Effects } \\
\text { Geography Controls } \\
\text { Colonial Controls } \\
\text { Planting-Month Fixed Effects } \\
\text { Harvest-Month Fixed Effects } \\
\text { Festival-Week Fixed Effects }\end{array}$ & $\begin{array}{l}\mathrm{N} \\
\mathrm{N} \\
\mathrm{N} \\
\mathrm{N} \\
\mathrm{N} \\
\mathrm{N}\end{array}$ & $\begin{array}{l}\mathrm{Y} \\
\mathrm{N} \\
\mathrm{N} \\
\mathrm{N} \\
\mathrm{N} \\
\mathrm{N}\end{array}$ & $\begin{array}{l}\mathrm{Y} \\
\mathrm{Y} \\
\mathrm{N} \\
\mathrm{N} \\
\mathrm{N} \\
\mathrm{N}\end{array}$ & $\begin{array}{l}\mathrm{Y} \\
\mathrm{Y} \\
\mathrm{Y} \\
\mathrm{N} \\
\mathrm{N} \\
\mathrm{N}\end{array}$ & $\begin{array}{l}\mathrm{Y} \\
\mathrm{Y} \\
\mathrm{Y} \\
\mathrm{Y} \\
\mathrm{Y} \\
\mathrm{Y}\end{array}$ \\
\hline $\begin{array}{l}\text { Observations } \\
\text { Adjusted R2 } \\
\text { Mean Dep. Var. } \\
\text { SD Dep. Var. }\end{array}$ & $\begin{array}{c}1,639 \\
0.002 \\
-0.576 \\
4.039\end{array}$ & $\begin{array}{c}1,639 \\
0.344 \\
-0.576 \\
4.039\end{array}$ & $\begin{array}{c}1,639 \\
0.564 \\
-0.576 \\
4.039\end{array}$ & $\begin{array}{c}1,639 \\
0.569 \\
-0.576 \\
4.039\end{array}$ & $\begin{array}{c}1,631 \\
0.588 \\
-0.578 \\
4.045\end{array}$ \\
\hline
\end{tabular}

Notes: Regressions in this table are identical to those in Table 2, except that municipalities with missing festival dates (previously not included in sample) are now included in the sample, and we assume that none of their festivals coincide with planting or harvest (for these observations, festival week randomly chosen among non-planting and non-harvest months for inclusion of Festival-Week Fixed Effects in column 5). Data is from the 2010 Mexico Population Census. Observations are municipalities in the New Spain region of Mexico. Robust standard errors are presented in parentheses and Conley (1999) standard errors calculated using a $100 \mathrm{~km}$ cut-off window are presented in brackets. Index of Economic Development is the first principal component index for a number of development outcomes in the census for a municipality (see Data Appendix). Festival Coincides with Maize Planting or Harvest is an indicator variable equal to 1 if the saint day festival in a municipality occurs either 0 to 30 days prior to the optimal maize planting date or 0 to 30 days after the optimal maize harvest date for a municipality using FAO GAEZ data. For this table, we assume all undetermined festival dates are not coinciding festivals. Geography Controls includes mean temperature, mean precipitation, mean land suitability, the surface area, centroid latitude, centroid longitude, mean elevation, mean slope, log distance to Mexico City, and mean maize suitability for the municipality. Colonial Controls includes drought intensity in 1545 and log population density in 1570 using data from Sellers and Alix-Garcia (2018). For these colonial controls, values for municipalities with missing information are set to zero, and we control for an indicator variable equal to 1 if the municipality is not missing these colonial characteristics. Planting $\mathcal{E}$ Harvest Month Fixed Effects includes fixed effects for the optimal planting-month and harvest-month for maize for each municipality according to FAO GAEZ data. Festival-Week Fixed Effects are fixed effects for the calendar date of the municipality's saint day festival. ${ }^{*} p<0.10,{ }^{* *} p<0.05,{ }^{* *} p<0.01$. 


\section{Table D10: Robustness to Including “Local” Patron Saints: Development Outcomes}

\begin{tabular}{|c|c|c|c|c|c|}
\hline & \multicolumn{5}{|c|}{$\begin{array}{l}\text { Dependent Variable: } \\
\text { Panel A: Log HH Income }\end{array}$} \\
\hline & $(1)$ & (2) & $(3)$ & $(4)$ & $(5)$ \\
\hline Festival Coincides with Maize Planting or Harvest & $\begin{array}{c}-0.261^{* * *} \\
(0.099) \\
{[0.109]}\end{array}$ & $\begin{array}{c}-0.183^{* *} \\
(0.080) \\
{[0.080]}\end{array}$ & $\begin{array}{c}-0.234^{* * *} \\
(0.070) \\
{[0.081]}\end{array}$ & $\begin{array}{c}-0.239^{* * *} \\
(0.070) \\
{[0.078]}\end{array}$ & $\begin{array}{c}-0.195^{* *} \\
(0.076) \\
{[0.073]}\end{array}$ \\
\hline $\begin{array}{l}\text { State Fixed Effects } \\
\text { Geography Controls } \\
\text { Colonial Controls } \\
\text { Planting-Month Fixed Effects } \\
\text { Harvest-Month Fixed Effects } \\
\text { Festival-Week Fixed Effects }\end{array}$ & $\begin{array}{l}\mathrm{N} \\
\mathrm{N} \\
\mathrm{N} \\
\mathrm{N} \\
\mathrm{N} \\
\mathrm{N}\end{array}$ & $\begin{array}{l}\mathrm{Y} \\
\mathrm{N} \\
\mathrm{N} \\
\mathrm{N} \\
\mathrm{N} \\
\mathrm{N}\end{array}$ & $\begin{array}{l}\mathrm{Y} \\
\mathrm{Y} \\
\mathrm{N} \\
\mathrm{N} \\
\mathrm{N} \\
\mathrm{N}\end{array}$ & $\begin{array}{l}\mathrm{Y} \\
\mathrm{Y} \\
\mathrm{Y} \\
\mathrm{N} \\
\mathrm{N} \\
\mathrm{N}\end{array}$ & $\begin{array}{l}\mathrm{Y} \\
\mathrm{Y} \\
\mathrm{Y} \\
\mathrm{Y} \\
\mathrm{Y} \\
\mathrm{Y}\end{array}$ \\
\hline $\begin{array}{l}\text { Observations } \\
\text { Adjusted R2 } \\
\text { Mean Dep. Var. } \\
\text { SD Dep. Var. }\end{array}$ & $\begin{array}{l}1,625 \\
0.003 \\
3.251 \\
1.329\end{array}$ & $\begin{array}{l}1,625 \\
0.347 \\
3.251 \\
1.329\end{array}$ & $\begin{array}{l}1,625 \\
0.537 \\
3.251 \\
1.329\end{array}$ & $\begin{array}{l}1,625 \\
0.543 \\
3.251 \\
1.329\end{array}$ & $\begin{array}{l}1,625 \\
0.565 \\
3.251 \\
1.329\end{array}$ \\
\hline \multirow{2}{*}{ SD Dep. Var. } & \multicolumn{5}{|c|}{$\begin{array}{l}\text { Dependent Variable: } \\
\text { Panel B. }\end{array}$} \\
\hline & $(1)$ & $(2)$ & $(3)$ & $(4)$ & $(5)$ \\
\hline Festival Coincides with Maize Planting or Harvest & $\begin{array}{c}-0.661^{* *} \\
(0.301) \\
{[0.352]}\end{array}$ & $\begin{array}{c}-0.350 \\
(0.243) \\
{[0.260]}\end{array}$ & $\begin{array}{c}-0.539^{* *} \\
(0.211) \\
{[0.230]}\end{array}$ & $\begin{array}{c}-0.559^{* * *} \\
(0.210) \\
{[0.225]}\end{array}$ & $\begin{array}{c}-0.491^{* *} \\
(0.225) \\
{[0.195]}\end{array}$ \\
\hline $\begin{array}{l}\text { State Fixed Effects } \\
\text { Geography Controls } \\
\text { Colonial Controls } \\
\text { Planting-Month Fixed Effects } \\
\text { Harvest-Month Fixed Effects } \\
\text { Festival-Week Fixed Effects }\end{array}$ & $\begin{array}{l}\mathrm{N} \\
\mathrm{N} \\
\mathrm{N} \\
\mathrm{N} \\
\mathrm{N} \\
\mathrm{N}\end{array}$ & $\begin{array}{l}\mathrm{Y} \\
\mathrm{N} \\
\mathrm{N} \\
\mathrm{N} \\
\mathrm{N} \\
\mathrm{N}\end{array}$ & $\begin{array}{l}\mathrm{Y} \\
\mathrm{Y} \\
\mathrm{N} \\
\mathrm{N} \\
\mathrm{N} \\
\mathrm{N}\end{array}$ & $\begin{array}{l}\mathrm{Y} \\
\mathrm{Y} \\
\mathrm{Y} \\
\mathrm{N} \\
\mathrm{N} \\
\mathrm{N}\end{array}$ & $\begin{array}{l}\mathrm{Y} \\
\mathrm{Y} \\
\mathrm{Y} \\
\mathrm{Y} \\
\mathrm{Y} \\
\mathrm{Y}\end{array}$ \\
\hline $\begin{array}{l}\text { Observations } \\
\text { Adjusted R2 } \\
\text { Mean Dep. Var. } \\
\text { SD Dep. Var. }\end{array}$ & $\begin{array}{c}1,625 \\
0.002 \\
-0.528 \\
4.048\end{array}$ & $\begin{array}{c}1,625 \\
0.349 \\
-0.528 \\
4.048\end{array}$ & $\begin{array}{c}1,625 \\
0.565 \\
-0.528 \\
4.048\end{array}$ & $\begin{array}{c}1,625 \\
0.570 \\
-0.528 \\
4.048\end{array}$ & $\begin{array}{c}1,625 \\
0.594 \\
-0.528 \\
4.048\end{array}$ \\
\hline
\end{tabular}

Notes: Regressions in this table are identical to those in Table 2, except that municipalities celebrating "local" saints (those not appearing in official Roman Catholic records outside of Mexico, previously not included in sample) are now included in the sample, and we use their actual festival celebration dates to determine whether they coincide with planting or harvest. Data are from the 2010 Mexico Population Census. Observations are municipalities in the New Spain region of Mexico. Robust standard errors are presented in parentheses and Conley (1999) standard errors calculated using a $100 \mathrm{~km}$ cut-off window are presented in brackets. Index of Economic Development is the first principal component index for a number of development outcomes in the census for a municipality (see Data Appendix). Festival Coincides with Maize Planting or Harvest is an indicator variable equal to 1 if the saint day festival in a municipality occurs either 0 to 30 days prior to the optimal maize planting date or 0 to 30 days after the optimal maize harvest date for a municipality using FAO GAEZ data. For this table, we assume all undetermined festival dates are not coinciding festivals. Geography Controls includes mean temperature, mean precipitation, mean land suitability, the surface area, centroid latitude, centroid longitude, mean elevation, mean slope, log distance to Mexico City, and mean maize suitability for the municipality. Colonial Controls includes drought intensity in 1545 and $\log$ population density in 1570 using data from Sellers and Alix-Garcia (2018). For these colonial controls, values for municipalities with missing information are set to zero, and we control for an indicator variable equal to 1 if the municipality is not missing these colonial characteristics. Planting $\&$ Harvest Month Fixed Effects includes fixed effects for the optimal planting-month and harvest-month for maize for each municipality according to FAO GAEZ data. Festival-Week Fixed Effects are fixed effects for the calendar date of the municipality's saint day festival. ${ }^{*} p<0.10,{ }^{* *} p<0.05$, ${ }^{* * *} p<0.01$ 


\section{Table D11: Impact of Agriculturally-Coinciding Festivals on Migration Outcomes}

\begin{tabular}{|c|c|c|c|c|}
\hline & \multicolumn{4}{|c|}{ Dependent Variables: } \\
\hline & $\begin{array}{c}\% \text { Born in a } \\
\text { Different State }\end{array}$ & $\begin{array}{c}\% \text { Different Municipality } \\
5 \text { Years Ago }\end{array}$ & $\begin{array}{c}\% \text { Different State } \\
5 \text { Years Ago }\end{array}$ & $\begin{array}{c}\% \text { Different Country } \\
5 \text { Years Ago }\end{array}$ \\
\hline & (1) & (2) & (3) & (4) \\
\hline Festival Coincides with Maize Planting or Harvest & $\begin{array}{r}-0.007 \\
(0.006) \\
{[0.005]}\end{array}$ & $\begin{array}{r}-0.001 \\
(0.002) \\
{[0.002]}\end{array}$ & $\begin{array}{r}-0.003^{*} \\
(0.001) \\
{[0.001]}\end{array}$ & $\begin{array}{l}0.004^{\text {*** }} \\
(0.001) \\
{[0.001]}\end{array}$ \\
\hline State Fixed Effects & Y & $\mathrm{Y}$ & Y & $\mathrm{Y}$ \\
\hline Geography Controls & Y & $\mathrm{Y}$ & $\mathrm{Y}$ & Y \\
\hline Colonial Controls & Y & Y & $\mathrm{Y}$ & $\mathrm{Y}$ \\
\hline Planting-Month Fixed Effects & Y & $\mathrm{Y}$ & Y & $\mathrm{Y}$ \\
\hline Harvest-Month Fixed Effects & Y & $\mathrm{Y}$ & Y & Y \\
\hline Festival-Week Fixed Effects & Y & Y & Y & Y \\
\hline Observations & 1,593 & 1,593 & 1,593 & 1,593 \\
\hline Adjusted R2 & 0.546 & 0.198 & 0.199 & 0.299 \\
\hline Mean Dep. Var. & 0.085 & 0.023 & 0.025 & 0.018 \\
\hline SD Dep. Var. & 0.103 & 0.029 & 0.022 & 0.015 \\
\hline
\end{tabular}

Notes: Data is from the 2010 Population Census. Observations are municipalities in the New Spain region of Mexico. Standard errors are clustered at the municipality level. \% Born in a Different State is the share of individuals in a municipality that report being born in a different state than their curren state of residence. \% Different Municipality 5 Years Ago is the share of individuals in a municipality who report having lived in a different municipality (but within the same state) five years ago. \% Different State 5 Years Ago is the share of individuals in a municipality who report having lived in a differen state five years ago. \% Different Country 5 Years Ago is the share of individuals in a municipality who report having lived abroad five years ago. Festival Coincides with Maize Planting or Harvest is an indicator variable equal to 1 if the saint day festival in a municipality occurs either 0 to 30 days prior to the optimal maize planting date or 0 to 30 days after the optimal maize harvest date for a municipality using FAO GAEZ data. Geography Controls includes mean temperature, mean precipitation, mean land suitability, the surface area, centroid latitude, centroid longitude, mean elevation, mean slope, log distance to Mexico City, and mean maize suitability for the municipality. Colonial Controls includes drought intensity in 1545 and log population density in 1570 using data from Sellers and Alix-Garcia (2018). For these colonial controls, values for municipalities with missing information are set to zero, and we control for an indicator variable equal to 1 if the municipality is not missing these colonial characteristics. Planting \& Harvest Month Fixed Effects includes fixed effects for the optimal planting-month and harvest-month for maize for each municipality according to FAO GAEZ data. Festival-Week Fixed Effects are fixed effects for the calendar week of the municipality's saint day festival. ${ }^{*} p<0.10,{ }^{* *} p<0.05,{ }^{* * *} p<0.01$. 


\section{Appendix References}

Catholic Church, Martirologio Romano, Vatican City: Typis Polyglottis Vaticanis, 1956.

_ , Calendarium Romanum, Vatican City: Typis Polyglottis Vaticanis, 1969.

Fischer, Gunther, Freddy Nachtergaele, Sylvia Prieler, Edmar Teixeira, Géza Tóth, Harrij van Velthuizen, Luc Verelst, and David Wiberg, "Global Agro-ecological Zones: Model Documentation," 2012. GAEZ ver 3.o Model Documentation, Food and Agriculture Organization of the United Nations (FAO).

Hijmans, R.J., S.E. Cameron, J.L. Parra, P.G. Jones, and A. Jarvis, "Very High Resolution Interpolated Climate Surfaces for Global Land Areas," International Journal of Climatology, 2005, 25, 1965-1978.

INAFED, Instituto Nacional para el Federalismo y el Desarrollo Municipal, "Enciclopedia de los Municipios y Delegaciones de México," 1988.

Michalopoulos, Stelios, "The Origins of Ethnolinguistic Diversity," American Economic Review, 2012, 102 (4), 1508-39.

Ramankutty, Navin, Jonathan A. Foley, John Norman, and Kevin McSweeney, "The Global Distribution of Cultivable Lands: Current Patterns and Sensitivity to Possible Climate Change," Global Ecology and Biogeography, 2002, 11, 377-392.

Sellers, Emily A. and Jennifer Alix-Garcia, "Labor Scarcity, Land Tenure, and Historical Legacy: Evidence from Mexico," Journal of Development Economics, 2018, 135, 504-516.

Watkins, Basil, The Book of Saints: A Comprehensive Biographical Dictionary, New York, United States: Bloomsbury Publishing Plc, 2015. 